\title{
Discovery of LOU064 (Remibrutinib), a Potent and Highly Selective Covalent Inhibitor of Bruton's Tyrosine Kinase
}

Daniela Angst $^{* a}$, François Gessier ${ }^{a}$, Philipp Janser ${ }^{a}$, Anna Vulpetti ${ }^{a}$, Rudolf Wälchli ${ }^{a}$, Christian

Beerli $^{b}$, Amanda Littlewood-Evans ${ }^{b}$, Janet Dawson $^{b}$, Barbara Nuesslein-Hildesheim ${ }^{b}$, Grazyna Wieczorek $^{b}$, Sascha Gutmann ${ }^{c}$, Clemens Scheufler ${ }^{c}$, Alexandra Hinniger ${ }^{c}$, Alfred Zimmerlin ${ }^{d}$, Enrico G. Funhoffe, Robert Pulz ${ }^{a}$, Bruno Cenni ${ }^{b}$

\section{Supporting Information}

Table of Contents:

Chemistry: S2 - S65

Structural Biology: S66 - S71

Table S-2: In vitro ADME profile of LOU064: S72

Biology: S73 - S93

Animal Studies: S94 - S95

References: S96 - S97 


\section{CHEMISTRY}

All chemicals were used directly as received from commercial suppliers. ${ }^{1} \mathrm{H}$ NMR and ${ }^{13} \mathrm{C}$ NMR spectra were recorded on Bruker 400 or 600 spectrometers. Chemical shifts are expressed in $\delta$ ppm referenced to the residual solvent peak (DMSO-d $6: \delta=2.50 \mathrm{ppm}$; $\mathrm{CDCl}_{3}: \delta=7.27 \mathrm{ppm}$; $\mathrm{CD}_{3} \mathrm{OD}$ : $\delta=3.30 \mathrm{ppm}$ ). Abbreviations used in describing peak signals are: $\mathrm{br}=$ broad signal, $\mathrm{s}=$ singlet, $\mathrm{d}$ $=$ doublet, $\mathrm{dd}=$ doublet of doublets, $\mathrm{t}=$ triplet, $\mathrm{q}=$ quartet, $\mathrm{m}=$ multiplet. All final compounds were purified to $>95 \%$ by reverse phase high performance liquid chromatography (HPLC), supercritical fluid chromatography (SFC) or normal phase silica gel column chromatography. The purity was assessed by reverse phase UPLC with a gradient of 5-98 \% acetonitrile in water (with either acid or base modifier) and monitored by UV absorption at 210-450 nM. Low-resolution mass spectra were recorded on liquid chromatography-mass spectrometer in electrospray positive (ES+) and negative (ES-) mode. The HR-MS analyses were performed by using electrospray ionization in positive ion modus after separation by liquid chromatography (Nexera from shimadzu). The elemental composition was derived from the mass spectra acquired at the high resolution of about 30'000 on an LTQ Orbitrap XL mass spectrometer (Thermo Scientific). The high mass accuracy below $1 \mathrm{ppm}$ was obtained by using a lock mass. 


\section{ABBREVIATIONS}

Aq: aqueous

BISPIN: bis(pinacolato)diboron

BOC: tert-butoxycarbonyl

nBuLi: n-butyllithium

DCE: dichlorethane

DCM: dichloromethane

DIAD: diisopropyl azodicarboxylate

DIPEA: diisopropylethylamine

DMB: 2,4-dimethoxybenzyl

DME: dimethoxyethane

DMF: dimethylformamide

DMSO: diemthylsulfoxide

EtOAc: ethyl acetate

EtOH: ethanol

h: hour(s)

HATU: 1-[Bis(dimethylamino)methylene]-1H-1,2,3-triazolo[4,5-b]pyridinium 3-oxid hexafluorophosphate

KOAc: potassium acetate

M: molar

$\mathrm{MeOH}$ : methanol

MTBE: methyl tert-butyl ether

NaHMDS: sodium bis(trimethylsilyl)amide

NBS: $N$-bromosuccinimide

min: minute(s)

$\mu \mathrm{W}$ : microwaves

PL- $\mathrm{HCO}_{3} \mathrm{MP}$ : Tetraalkylammonium carbonate polymer bound

iPrOH : isopropanol

$\mathrm{PdCl}_{2}\left(\mathrm{PPh}_{3}\right)_{2}$ : bis(triphenylphosphine)palladium(II) dichloride

$\mathrm{Pd}\left(\mathrm{PPh}_{3}\right)_{4}$ : tetrakis(triphenylphosphine)palladium(0)

RT: room temperature 
RF: reflux

$\mathrm{SiO}_{2}$ : silica

Smopex-301: styryl diphenylphosphine grafted polyolefin fiber

SPE: solid phase extraction

T3P: propylphosphonic anhydride

TEA: triethylamine

THF: tetrahydrofuran

TFA: trifluoroacetic acid 
S-3 was prepared in an analogous fashion to $\mathbf{3 8}$ starting from methyl 4-bromo-benzoate (S-1). Introduction of the cyclopropyl moiety through Suzuki reaction, followed by a sodium bis(trimethylsilyl)amide mediated coupling with $\mathbf{3 5}$ gave the desired boronate S-3.

Scheme S1: Preparation of boronic ester intermediate S-3. ${ }^{a}$

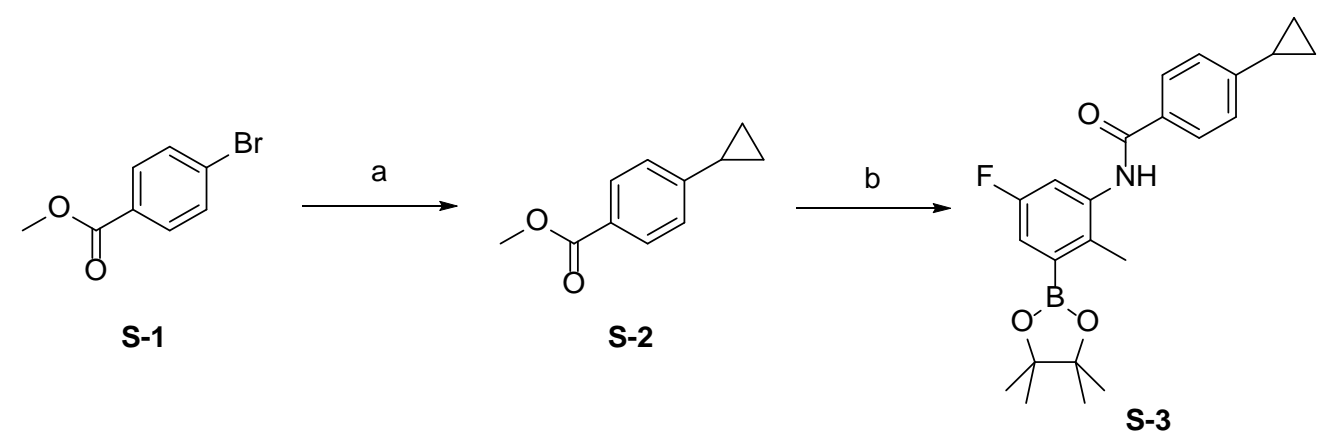

${ }^{a}$ Reagents and conditions: (a) cyclopropylboronic acid, $\mathrm{Pd}\left(\mathrm{PPh}_{3}\right)_{4}, \mathrm{~K}_{3} \mathrm{PO}_{4}$, water, toluene, $110{ }^{\circ} \mathrm{C}$, 30 h, 96 \%; (b) 35, NaHMDS (1 M in THF), THF, RT 6 h, $72 \%$.

S-10 was prepared from 3-fluoro-4-methylbenzoic acid (S-4) via dibromination with NBS, followed by treatment with silver nitrate to provide aldehyde S-6. Esterification of the carboxylic acid and oxidation of the aldehyde with sulfamic acid and sodium chlorite afforded S-8. Treatment with methylmagnesium bromide gave S-9, which was coupled with aniline $\mathbf{3 5}$ to yield $\mathbf{S - 1 0 .}$ 
Scheme S2: Preparation of boronic ester intermediates S-10. ${ }^{a}$<smiles>Cc1ccc(C(=O)O)cc1C=O</smiles><smiles>COC(=O)c1ccc(C(=O)O)c(F)c1</smiles><smiles>Cc1c(NC(=O)c2ccc(C(C)(C)O)cc2F)cc(F)cc1B1OC(C)(C)C(C)(C)O1</smiles>

${ }^{a}$ Reagents and conditions: (a) NBS, benzoyl peroxide, $\mathrm{CCl}_{4}, \mathrm{RF}, 24 \mathrm{~h}$; (b) silver nitrate, water, EtOH, $50{ }^{\circ} \mathrm{C}, 1$ h, 69 \% over 2 steps; (c) sodium hydride, iodomethane, DMF, RT, 18 h, 92 \%; (d) sulfamic acid, sodium chlorite, acetonitrile, water, RT, 1 h, 46 \%; (e) methylmagnesium bromide (3 M in THF), THF, $0{ }^{\circ} \mathrm{C}, 4$ h, 67 \%; (f) 35, HATU, DIPEA, DMF, $50{ }^{\circ} \mathrm{C}$, overnight, $71 \%$.

Boronic ester S-15 was obtained from 2,3-difluoro-4-methylbenzoic acid (S-11), which after esterification was subjected to methylmagnesium bromide treatment to yield S-13. The methyl group was oxidized with potassium permanganate to the carboxylic acid (S-14) which was coupled with 35 and HATU to yield S-15. 
Scheme S3: Preparation of boronic ester intermediates S-15. ${ }^{a}$
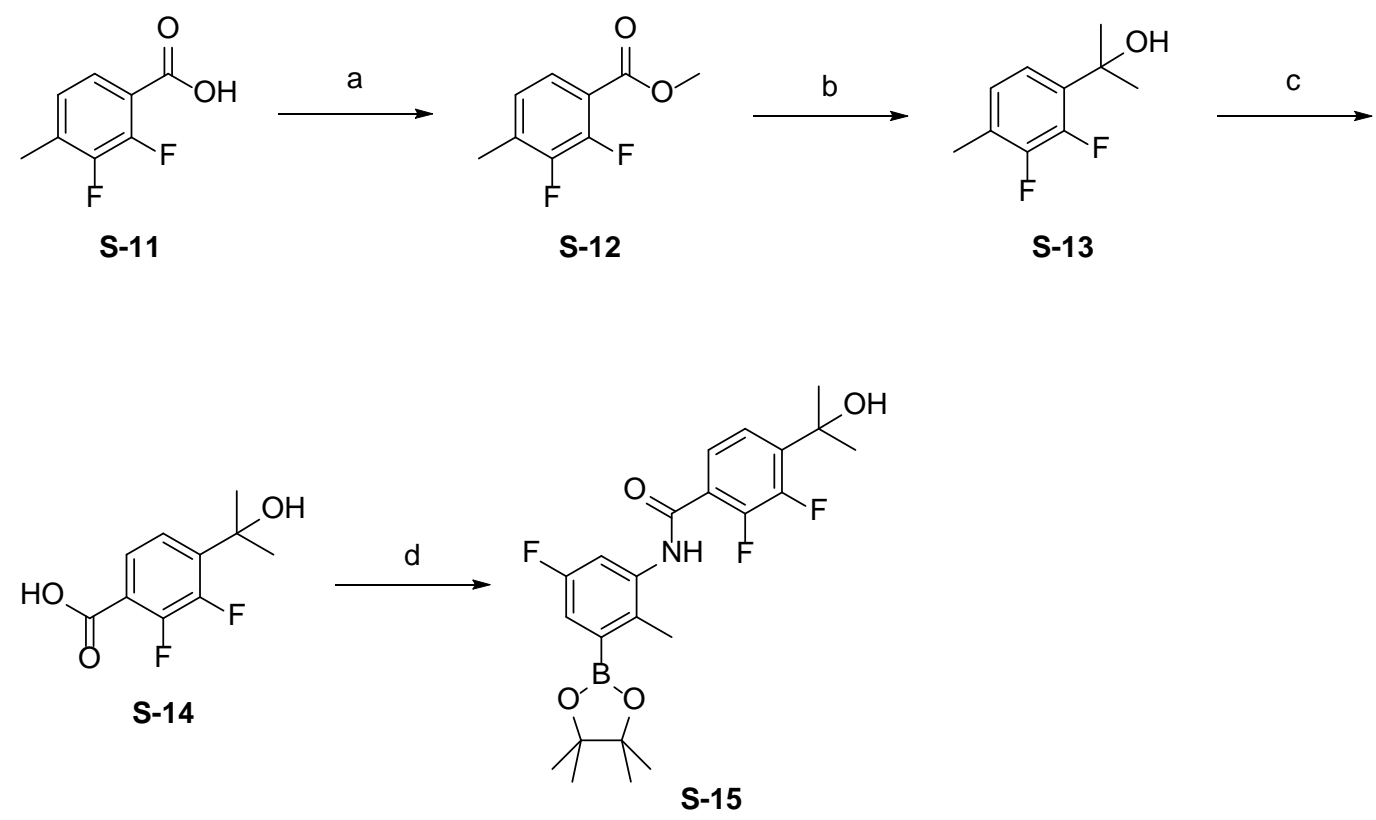

${ }^{a}$ Reagents and conditions: (a) thionylchloride, $\mathrm{MeOH}, 15{ }^{\circ} \mathrm{C}, 18 \mathrm{~h}, 97 \%$; (b) methylmagnesium bromide ( $3 \mathrm{M}$ in THF), THF, $0{ }^{\circ} \mathrm{C}, 1 \mathrm{~h}$, quant; (c) potassium permanganate, water, $95^{\circ} \mathrm{C}, 3 \mathrm{~h}$, $35 \%$; (d) 35, HATU, DIPEA, DMF, $60{ }^{\circ} \mathrm{C}, 4$ h, $66 \%$.

Compound 9 was accessed via Suzuki coupling of 4-amino-6-chloropyrimidine (S-16) and boronic ester S-3. 
Scheme S4: Preparation of $9 .^{a}$

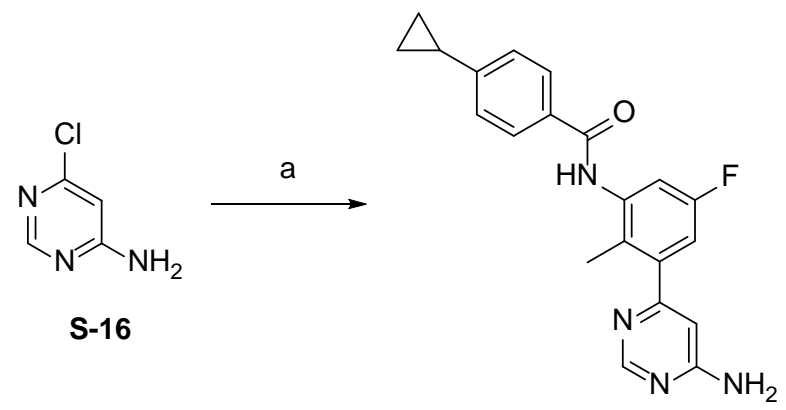

9

${ }^{a}$ Reagents and conditions: (a) S-3, aq $\mathrm{NaHCO}_{3}, \mathrm{Pd}\left(\mathrm{PPh}_{3}\right)_{4}$, water, DME, $80{ }^{\circ} \mathrm{C}, 5$ h, $39 \%$.

Boronic ester S-19 was obtained by treating dichloromethane with $n$-butyllithium, trimethylborate and pinacol followed by a Takai reaction with N-Boc-(methylamino)acetaldehyde using chromium dichloride and lithium iodide., ${ }^{1,2}$ S-20 was obtained via Takai reaction of $\mathbf{S - 1 8}$ and N-Boc-3(methylamino)-propanal.

Scheme S5: Preparation of intermediate S-19 and S-20. ${ }^{a}$

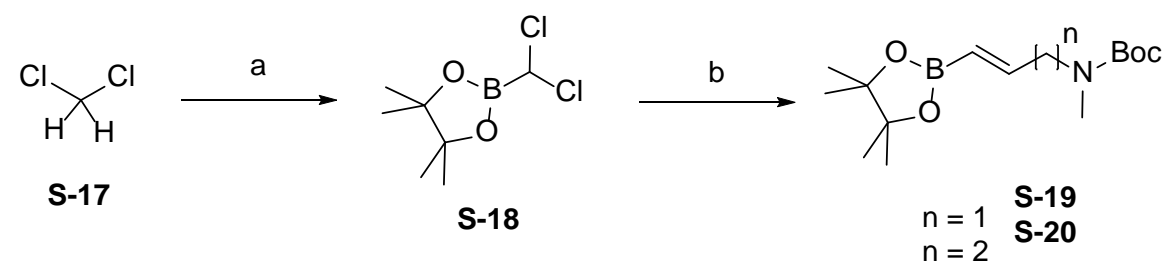

${ }^{a}$ Reagents and conditions: (a) 1) $n \mathrm{BuLi}$, trimethyl borate, $-100{ }^{\circ} \mathrm{C}, 30 \mathrm{~min}$; 2) pinacol, benzene, RF, 48 h, 61 \%; (b) N-Boc-(methylamino)acetaldehyde, chromium dichloride, lithium iodide, THF, RT, 17 h, 93 \% for S-19 and N-Boc-3-(methylamino)-propanal, chromium dichloride, lithium iodide, THF, RT, overnight, 47 \% for S-20. 
Alkenyl derivatives $\mathbf{1 0}$ and $\mathbf{1 1}$ were prepared starting from 4,6-dichloro-5-iodopyrimidine which was treated with 2,4-dimethoxybenzylamine to give S-22 followed by Suzuki coupling with boronic esters S-19 or S-20, respectively. Chloropyrimidines S-23 and S-26 were then individually subjected to a second Suzuki reaction with boronic ester S-3. The syntheses were completed by concomitant deprotection of the Boc and the dimethoxybenzyl groups with TFA followed by formation of the acrylamides $\mathbf{1 0}$ and $\mathbf{1 1}$ with acryloyl chloride. To avoid the formation of side products substoichiometric amounts of acryloyl chloride were used. 
Scheme S6: Preparation of $\mathbf{1 0}$ and $11 .^{a}$

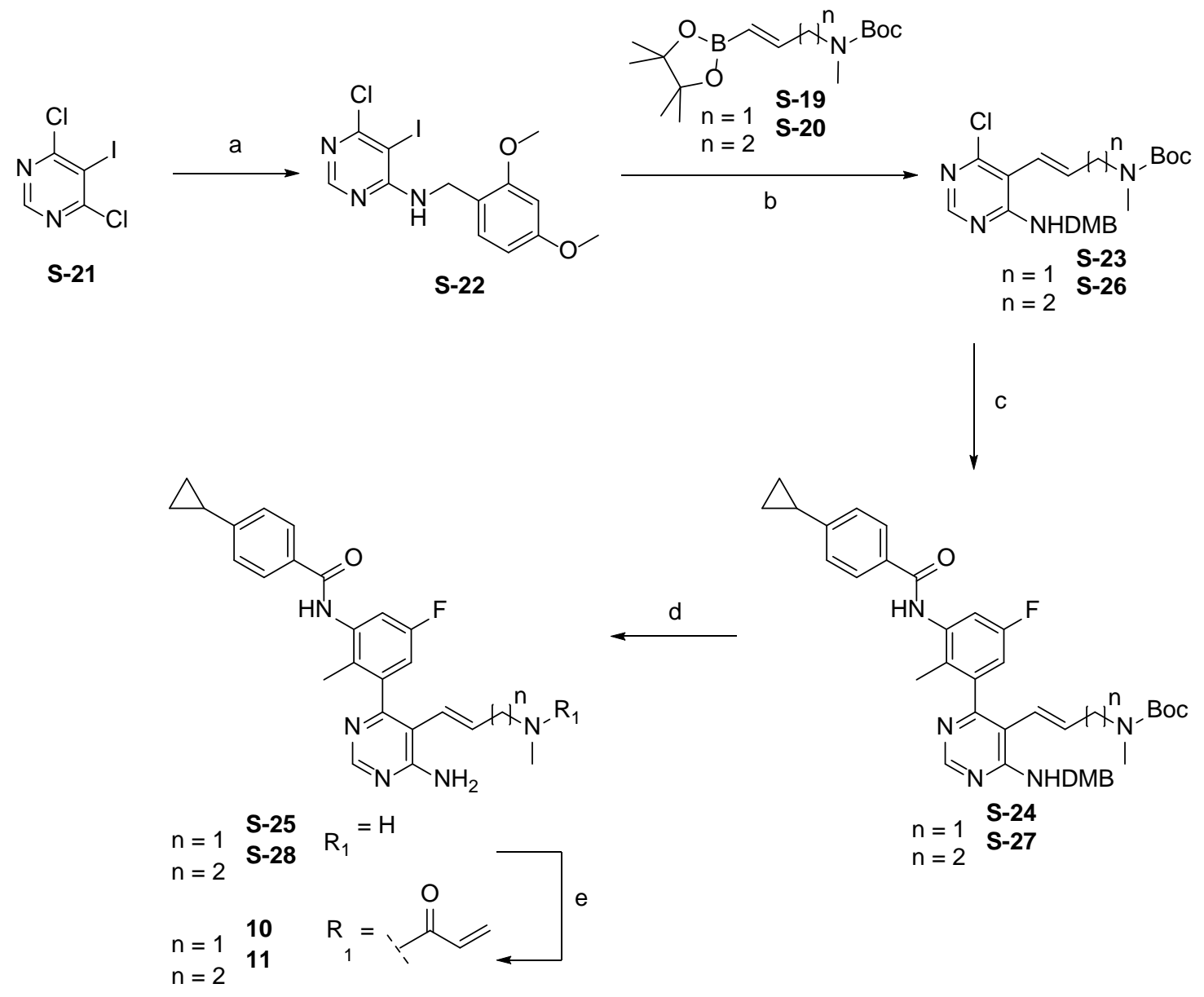

${ }^{a}$ Reagents and conditions: (a) 2,4-dimethoxybenzylamine, dioxane, $60{ }^{\circ} \mathrm{C}, 3 \mathrm{~h}, 80 \%$; (b) aq $\mathrm{Na}_{2} \mathrm{CO}_{3}, \mathrm{PdCl}_{2}\left(\mathrm{PPh}_{3}\right)_{2}$, water, DME, $85^{\circ} \mathrm{C}, 4$ h, $74 \%$ (S-23) and $70 \%$ (S-26) ; (c) S-3, aq $\mathrm{Na}_{2} \mathrm{CO}_{3}$, $\mathrm{PdCl}_{2}\left(\mathrm{PPh}_{3}\right)_{2}$, water, DME, $85{ }^{\circ} \mathrm{C}, 4$ h, $62 \%$ (S-24) and $67 \%$ (S-27); (d) TFA, DCE, $80{ }^{\circ} \mathrm{C}, 17-$ 36 h, 76 \% (S-25) and 75 \% (S-28); (e) acryloyl chloride, TEA, DCM, RT, 1-1.5 h, 22 \% (10) and $45 \%$ (11).

For the synthesis of derivatives 12, 13 and 14, 4-amino-6-chloro-5-pyrimidinol (41) was alkylated with either N-Boc-3-bromopyrrolidine or N-Boc-3-iodoazetidine and potassium carbonate to give 
intermediates S-29 or S-32, respectively. Suzuki coupling of S-29 and S-32 with S-3 followed by Boc deprotection and acrylamide formation with acryloyl chloride provided 12 and 13, respectively. 14 was obtained from S-32 in an analogous fashion using 38 for the Suzuki coupling instead of S-3 and acrylic acid and T3P for the acrylamide formation. 
Scheme S7: Preparation of 12, 13 and $14 .^{a}$

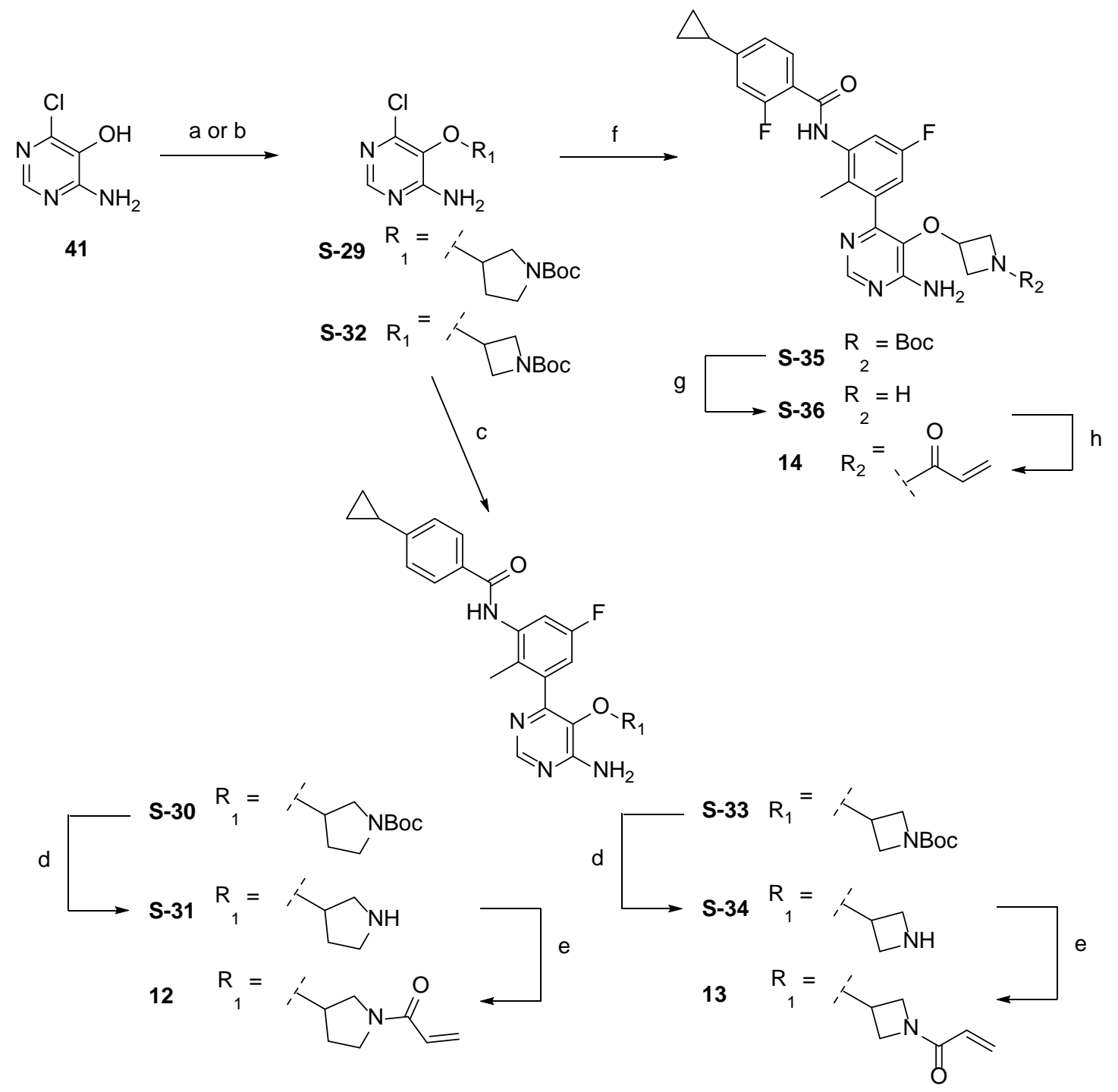

${ }^{a}$ Reagents and conditions: (a) N-Boc-3-bromopyrrolidine, $\mathrm{K}_{2} \mathrm{CO}_{3}$, DMF, $100{ }^{\circ} \mathrm{C}, \mu \mathrm{W}, 1 \mathrm{~h}, 70 \%$; (b) N-Boc-3-iodoazetidine, $\mathrm{K}_{2} \mathrm{CO}_{3}$, DMF, $100{ }^{\circ} \mathrm{C}, 16 \mathrm{~h}, 56 \%$; (c) S-3, aq $\mathrm{Na}_{2} \mathrm{CO}_{3}, \mathrm{PdCl}_{2}\left(\mathrm{PPh}_{3}\right)_{2}$, water, DME, 85 C, 12-24 h, 46 \% (S-30) and $62 \%$ (S-33); (d) TFA, DCM, RT, 4-6 h, 87 \% (S-31) and 88 \% (S-34); (e) acryloyl chloride, TEA, DCM, RT, 1 h, 37 \% (12) and $49 \%$ (13); (f) 38, aq $\mathrm{Na}_{2} \mathrm{CO}_{3}, \mathrm{PdCl}_{2}\left(\mathrm{PPh}_{3}\right)_{2}$, DME, water, $110{ }^{\circ} \mathrm{C}, \mu \mathrm{W}, 25$ min, 45 \%; (g) TFA, DCM, RT, 23 h, 74 \%; (h) acrylic acid, T3P in DMF, DIPEA, DMF, $0{ }^{\circ} \mathrm{C}, 100 \mathrm{~min}, 64 \%$. 
In an analogous fashion to $\mathbf{1 3}$ (cf. Scheme S7), examples $\mathbf{1 5}$ and $\mathbf{1 6}$ were obtained by Suzuki reaction of S-32 with S-10 or S-15, respectively, followed by Boc deprotection and formation of the acrylamide.

Scheme S8: Preparation of $\mathbf{1 5}$ and $16 .^{a}$

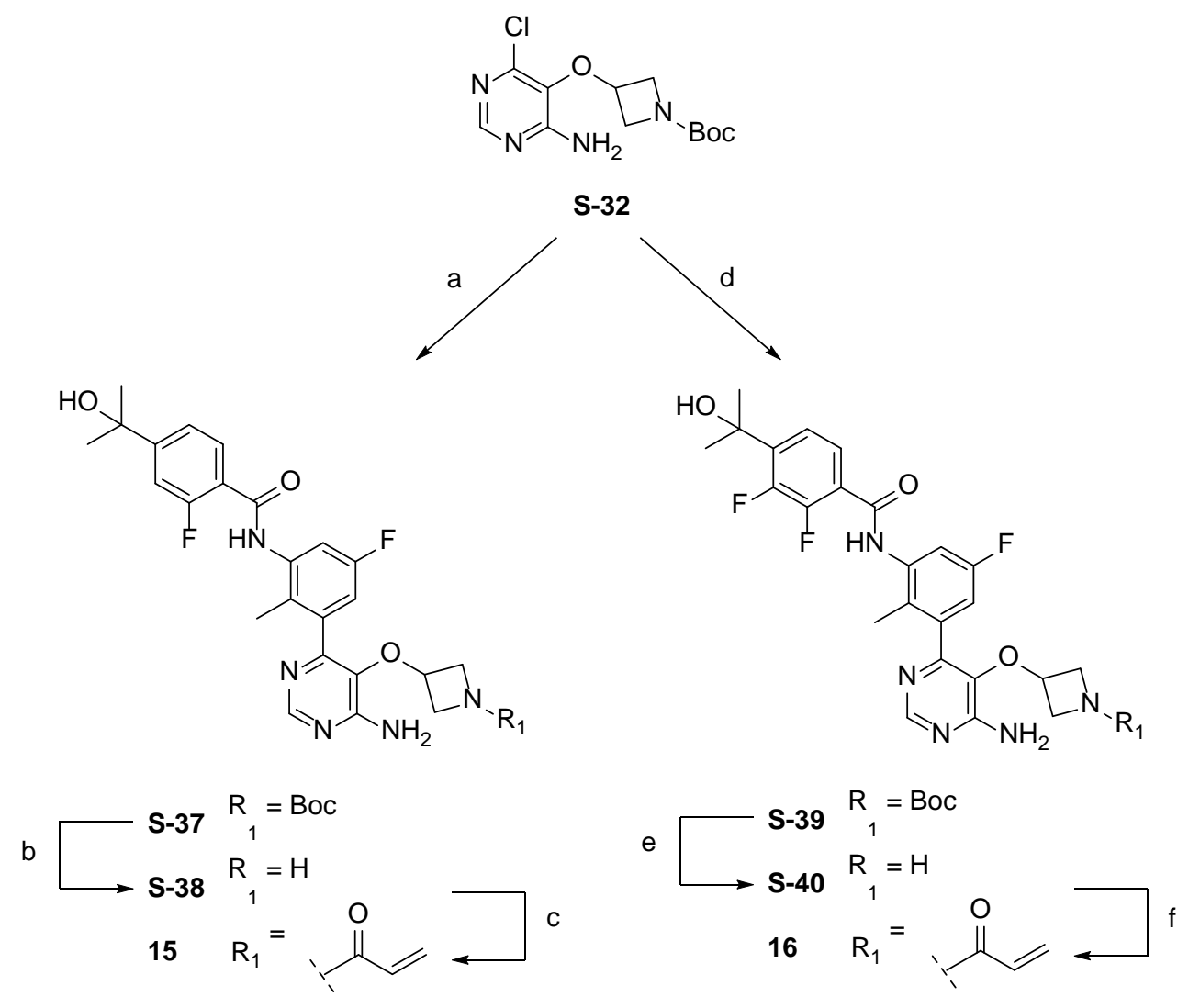

${ }^{a}$ Reagents and conditions: (a) S-10, aq $\mathrm{Na}_{2} \mathrm{CO}_{3}, \mathrm{PdCl}_{2}\left(\mathrm{PPh}_{3}\right)_{2}$, DME, water, $85^{\circ} \mathrm{C}, 6 \mathrm{~h}, 62 \%$; (b) TFA, DCM, RT, 6 h, 76 \%; (c) acryloyl chloride, TEA, DCM, RT, 1 h, 58 \%; (d) S-15, aq $\mathrm{Na}_{2} \mathrm{CO}_{3}$, $\mathrm{PdCl}_{2}\left(\mathrm{PPh}_{3}\right)_{2}$, DME, water, $85{ }^{\circ} \mathrm{C}, 6$ h, 67 \%; (e) TFA, DCM, RT, 14 h, 80 \%; acryloyl chloride, TEA, DCM, RT, 1.5 h, $36 \%$. 
Compound 17 was prepared in a similar way to 10 (cf. Scheme S6), utilizing 4-amino-6-chloro-5iodo-pyrimidine (S-41) for the Suzuki reaction with S-19 instead of using PMB protected S-22. S41 was obtained by treating 4,6-dicholoro-5-iodopyrimidine with ammonia in isopropanol. A second Suzuki coupling with $\mathbf{3 8}$ provided S-43, which was subjected to TFA deprotection followed by treament with acryloylchloride to give $\mathbf{1 7}$.

Scheme S9: Preparation of $17 .^{a}$
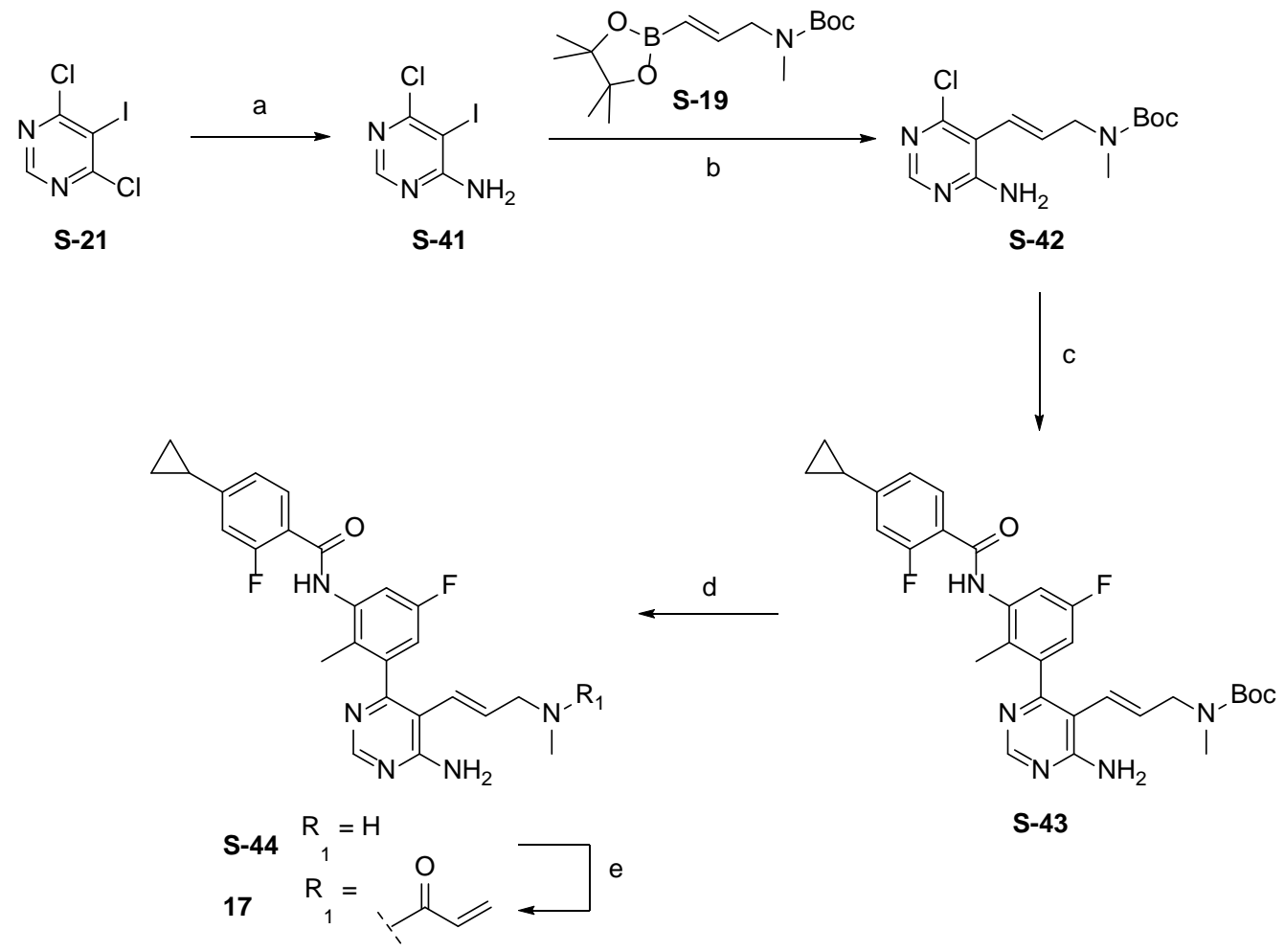

${ }^{a}$ Reagents and conditions: (a) aq $\mathrm{NH}_{4} \mathrm{OH}$, $\mathrm{PrOH}, 70{ }^{\circ} \mathrm{C}, 15 \mathrm{~h}, 80$ \%; (b) aq $\mathrm{Na}_{2} \mathrm{CO}_{3}, \mathrm{PdCl}_{2}\left(\mathrm{PPh}_{3}\right)_{2}$, water, DME, $80{ }^{\circ} \mathrm{C}$, 15 h, 64 \%; (c) 38, aq $\mathrm{Na}_{2} \mathrm{CO}_{3}, \mathrm{PdCl}_{2}\left(\mathrm{PPh}_{3}\right)_{2}$, water, $\mathrm{DME}, 80{ }^{\circ} \mathrm{C}, 15$ h, 55 \%; (d) TFA, DCM, RT, 12 h, 82 \%; (e) acryloyl chloride, TEA, DCM, RT, 1 h, 33 \%. 
Derivative 18 was obtained by reaction of 4-amino-6-chloro-pyrimidinol (41) and N-Bochydroxyethylamine under Mitsunobu conditions using DIAD and Smopex-301, followed by Suzuki reaction with 38, Boc deprotection and formation of the acrylate. Example 19 was obtained by reductive amination of 4,5-diamino-6-chloropyrimidine (S-48) and N-Boc-aminoacetaldehyde with decaborane, Suzuki coupling with $\mathbf{3 8}$ and Boc deprotection with TFA to yield S-51, which was treated with acrylic acid to give the final product. 
Scheme S10: Preparation of 18 and $19 .^{a}$
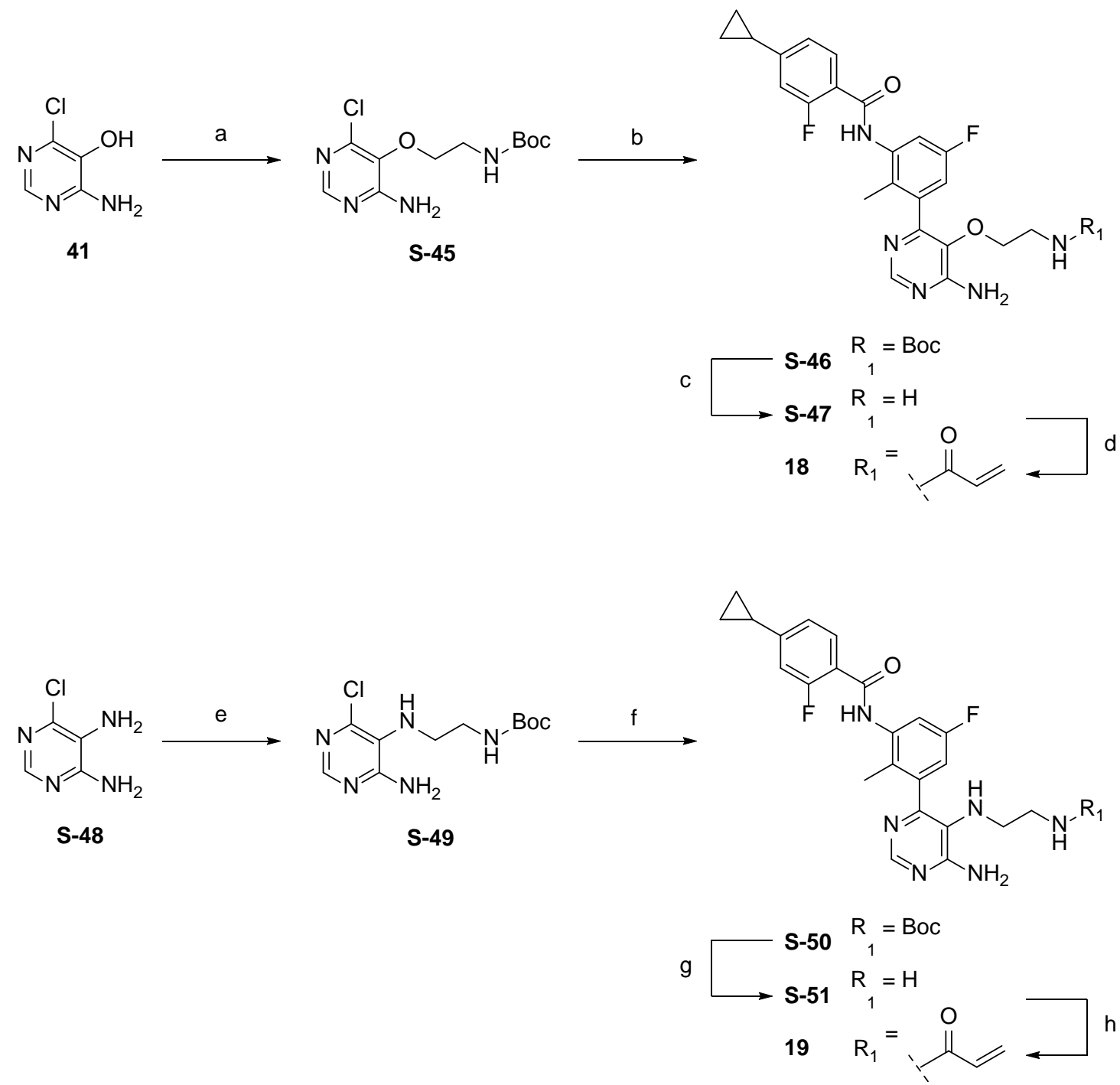

${ }^{a}$ Reagents and conditions: (a) N-Boc-hydroxyethylamine, DIAD, Smopex-301, THF, $60{ }^{\circ} \mathrm{C}, 2 \mathrm{~h}$, 54 \%; (b) 38, aq $\mathrm{Na}_{2} \mathrm{CO}_{3}, \mathrm{PdCl}_{2}\left(\mathrm{PPh}_{3}\right)_{2}$, DME, water, $\mu \mathrm{W}, 110{ }^{\circ} \mathrm{C}, 30$ min, 77 \%; (c) TFA, DCM, RT, 15 h; (d) acrylic acid, DIPEA, T3P in DMF, DMF, $0{ }^{\circ} \mathrm{C}$, 30 min, $60 \%$ over 2 steps; (e) NBoc-aminoacetaldehyde, decaborane, $\mathrm{MeOH}, \mathrm{RT}, 45$ h, 46 \%; (f) 38, aq $\mathrm{Na}_{2} \mathrm{CO}_{3}, \mathrm{PdCl}_{2}\left(\mathrm{PPh}_{3}\right)_{2}$, DME, water, $\mu \mathrm{W}, 120^{\circ} \mathrm{C}, 15$ min, 43 \%; (g) TFA, DCM, RT, 15 h; (h) acrylic acid, T3P in DMF, DIPEA, DMF, $0{ }^{\circ} \mathrm{C}, 2 \mathrm{~h}, 63 \%$ over 2 steps. 
Intermediates S-53 and S-55 were obtained by borane reduction of the carboxylic acids S-52 and S-54, respectively.

Scheme S11: Preparation of S-53 and S-55. ${ }^{a}$

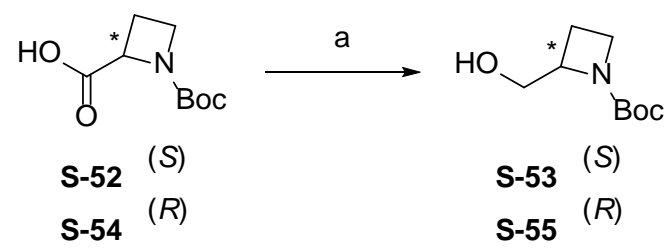

${ }^{a}$ Reagents and conditions: (a) $\mathrm{BH}_{3} \cdot \mathrm{THF}, \mathrm{THF}, \mathrm{RT}, 12$ h, 86-90 \%.

The series of pyrimidine ether derivatives 20 to $\mathbf{2 4 ,} 26$ and 27 were accessed by either alkylation of the pyrimidinol $\mathbf{4 1}$ with 4-iodopiperidine or by subjecting pyrimidinol $\mathbf{4 1}$ to a Mitsunobu reaction with the corresponding alcohols to afford S-56a to S-56g. These chloropyrimidines were subjected to a Suzuki coupling with 38, followed by Boc deprotection with either TFA oder HCl to yield S-58a to S-58g. The synthesis was completed by acrylamide formation either with acryloyl chloride or acrylic acid to give final products 20 to 24, 26 and 27. 
Scheme S12: Preparation of 20-24, 26 and 27.

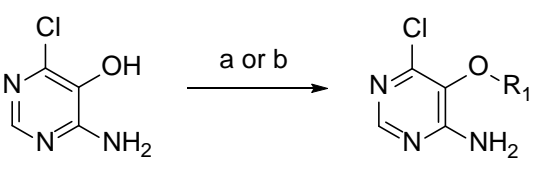

41

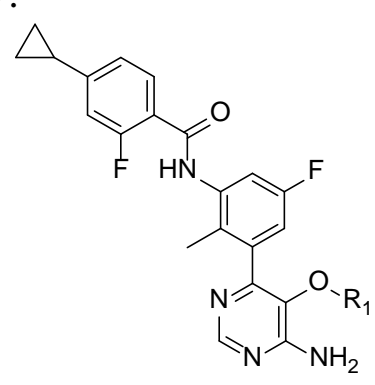

$\mathrm{S}-57 \mathrm{P}_{1}^{\mathrm{R}}=\mathrm{N}_{\mathrm{NBOC}}$

S-57b ${ }_{1}^{\mathrm{R}}=\mathrm{C}_{\mathrm{B} \text { oc }}^{\mathrm{N}}$

S-57c ${ }_{1}^{R}=$

S-57d ${ }^{R}=, \square_{\text {NBoc }}$

S-57e ${ }_{1}^{\mathrm{R}}=, \overbrace{\mathrm{NBoc}}$

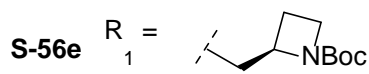

S-56f ${ }_{1}^{\mathrm{R}}=\mathrm{N}_{\text {Boc }}^{N_{\text {Boc }}}$

S-56g ${ }_{1}^{\mathrm{R}}=$

S-57g ${ }_{1}^{\mathrm{R}=} \mathrm{N}_{\mathrm{N}^{-} \mathrm{Boc}}$

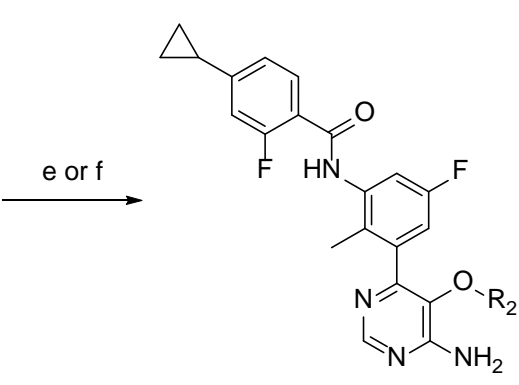

S-58a ${ }_{2}^{\mathrm{R}}=\mathrm{N}_{\mathrm{NH}}$

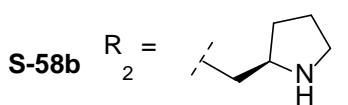

S-58c $\begin{gathered}\mathrm{R}_{2}= \\ \mathrm{N}_{\mathrm{N}}\end{gathered}$

S-58d ${ }_{2}^{R}=, \square_{N H}$

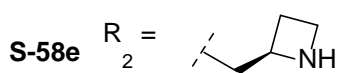

S-58f $\mathrm{R}_{2}=\overbrace{\mathrm{NH}}^{\text {I }}$

S-58g $\mathrm{R}_{2}=$ $\mathrm{g}$ or $\mathrm{h}$

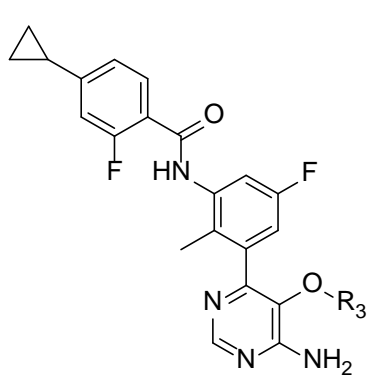

20

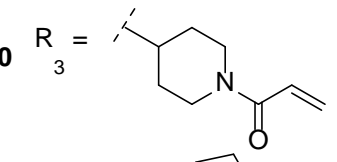

$21_{3}^{\mathrm{R}}=$

O>

$22_{3}^{R}=, \square_{N}$

O>

$23{ }_{3}=, \square_{N}$

) 1

$24_{3}^{\mathrm{R}}=\square_{\mathrm{N}}$

O)

S-57f ${ }_{1}^{\mathrm{R}}=$
$26_{3}^{\mathrm{R}}=\mathrm{N}^{\mathrm{N}}$

$27 \mathrm{R}_{3}^{\mathrm{R}=}$

${ }^{a}$ Reagents and conditions: (a) N-Boc-4-iodopiperidine, $\mathrm{K}_{2} \mathrm{CO}_{3}$, DMF, $80{ }^{\circ} \mathrm{C}, 9$ h, 55 \%; (b) $\mathrm{R}_{1}-\mathrm{OH}, \mathrm{DIAD}, \mathrm{Smopex}-301$, THF, $60{ }^{\circ} \mathrm{C}$, 2-18 hr, 25-74 \%; (c) 38, aq $\mathrm{Na}_{2} \mathrm{CO}_{3}, \mathrm{PdCl}_{2}\left(\mathrm{PPh}_{3}\right)_{2}$, DME, water, $\mu \mathrm{W}, 110{ }^{\circ} \mathrm{C}, 10-30$ min, 45-81 \%; (d) 38, aq NaHCO ,

$\mathrm{PdCl}_{2}\left(\mathrm{PPh}_{3}\right)_{2}$, DME, water, $90^{\circ} \mathrm{C}, 24$ h, 56 \%; (e) TFA, DCM, RT, 4-72 h, 86 \%-quant; (f) HCl, DCM, RT, 18 h, 94 \%; (g) acryloyl chloride, TEA, DCM, RT, 1 h, 36 \%; (h) acrylic acid, DIPEA, T3P, DMF, $0{ }^{\circ} \mathrm{C}-\mathrm{RT}, 1-4.5$ h, 30-67 \%. 
The warhead modified derivatives 28 to 32 were prepared from amine $\mathbf{4 4}$ by amide coupling with the corresponding carboxylic acids S-59 to S-63 and T3P.

Scheme S13: Preparation of 28 to $32 .^{a}$

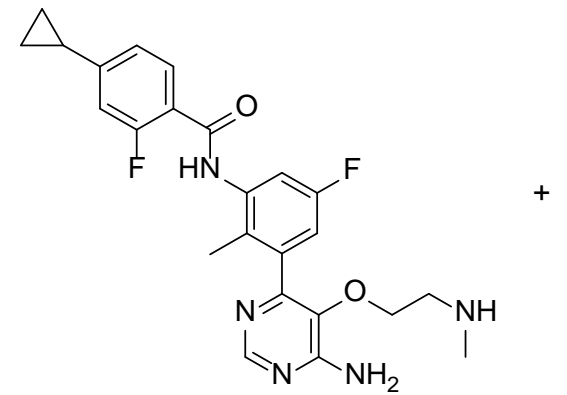

44

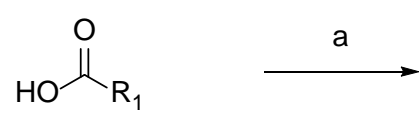

S-59 $\begin{gathered}\mathrm{R}= \\ 1\end{gathered}$
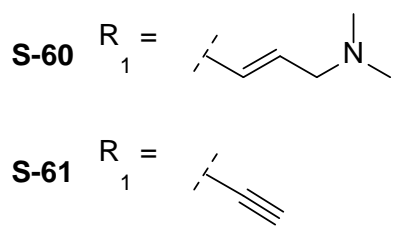

S-62 ${ }_{1}^{R}$

S-63 ${ }_{1}^{R}=$

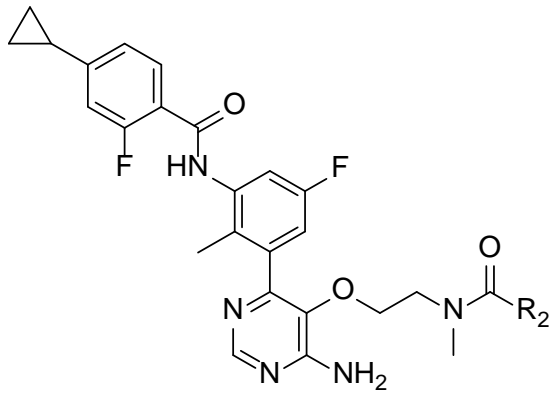

$28{ }_{2}^{\mathrm{R}}=$

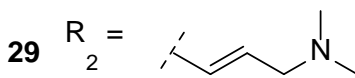

$30 \stackrel{\mathrm{R}}{2}$

$31 \quad \mathrm{R}=$

$32 \mathrm{R}_{2}=$

${ }^{a}$ Reagents and conditions: (a) DIPEA, T3P, DMF, $0^{\circ} \mathrm{C}-\mathrm{RT}, 0.5-4$ h, 9-94 \%. 


\section{Experimental Details}

\section{Methyl 4-cyclopropylbenzoate (S-2)}

To a solution of methyl 4-bromobenzoate $(20.00 \mathrm{~g}, 93.00 \mathrm{mmol})$ in toluene $(500 \mathrm{~mL})$ was added water (50 mL) followed by cyclopropylboronic acid (11.98 g, $140.00 \mathrm{mmol})$ and tripotassium phosphate (39.50 g, $186.00 \mathrm{mmol})$. The mixture was purged with argon for $30 \mathrm{~min}$, then $\mathrm{Pd}\left(\mathrm{PPh}_{3}\right)_{4}$ (1.08 g, $0.93 \mathrm{mmol}$ ) was added and the reaction mixture was stirred at $110{ }^{\circ} \mathrm{C}$ for $24 \mathrm{~h}$. More cyclopropylboronic acid (4.01 g, $46.67 \mathrm{mmol})$ and $\mathrm{Pd}\left(\mathrm{PPh}_{3}\right)_{4}(0.54 \mathrm{~g}, 0.47 \mathrm{mmol})$ were added and stirring was continued at $110^{\circ} \mathrm{C}$ for another $24 \mathrm{~h}$. Then, another portion of cyclopropylboronic acid (4.01 g, $46.67 \mathrm{mmol})$ and $\mathrm{Pd}\left(\mathrm{PPh}_{3}\right)_{4}(0.54 \mathrm{~g}, 0.47 \mathrm{mmol})$ were added and the reaction mixture was stirred at $110^{\circ} \mathrm{C}$ for an additional $6 \mathrm{~h}$. After cooling to RT the mixture was diluted with EtOAc and saturated aqueous $\mathrm{NaHCO}_{3}$ solution. The organic layer was separated, washed with saturated aqueous $\mathrm{NaHCO}_{3}$ solution and brine, dried over MgSO4, filtered and concentrated. The residue

was purified by column chromatography $\left(\mathrm{SiO}_{2}\right.$; heptane/EtOAc gradient) to afford $\mathbf{S}-\mathbf{2}$ as a colorless oil. Yield: $96 \%$. [ES-MS] (ESI+): m/z calcd for $\mathrm{C}_{11} \mathrm{H}_{13} \mathrm{O}_{2}[\mathrm{M}+\mathrm{H}]^{+}$, 177.1; found, 177.0. ${ }^{1} \mathrm{H}$ NMR (400 MHz, Chloroform-d) $\delta 7.91$ (d, 2H), 7.10 (d, 2H), 3.89 (s, 3H), 2.00 - 1.87 (m, 1H), $1.10-0.96(\mathrm{~m}, 2 \mathrm{H}), 0.82-0.69(\mathrm{~m}, 2 \mathrm{H})$.

\section{4-Cyclopropyl-N-(5-fluoro-2-methyl-3-(4,4,5,5-tetramethyl-1,3,2-dioxaborolan-2- yl)phenyl)benzamide (S-3)}

To a solution of S-2 $(6.11 \mathrm{~g}, 34.60 \mathrm{mmol})$ and $35(5.80 \mathrm{~g}, 23.10 \mathrm{mmol})$ in THF $(60 \mathrm{~mL})$ at $0{ }^{\circ} \mathrm{C}$ was added NaHMDS (1 M in THF, $34.6 \mathrm{~mL}, 34.6 \mathrm{mmol}$ ) dropwise. The now dark brown reaction mixture was stirred at RT for $6 \mathrm{~h}$. Three more portions of NaHMDS (1 M in THF, $8.0 \mathrm{~mL}$, $8.0 \mathrm{mmol}$ ) were added after 2,3 , and $5 \mathrm{~h}$, respectively. Water was added and the mixture was 
extracted with EtOAc. The organic layer was washed with saturated aqueous $\mathrm{NaHCO}_{3}$ solution and brine, dried over $\mathrm{MgSO}_{4}$, filtered and concentrated under reduced pressure. The residue was triturated with dichloromethane/cyclohexane (1:1). The solid was filtered off, the mother liquor was concentrated and the residue was triturated with ethylacetate/cyclohexane (1:1). The solid was filtered off, combined with the first solid and dried in vacuo to afford S-3. Yield: 76 \%. [ES-MS] (ESI+): $\mathrm{m} / \mathrm{z}$ calcd for $\mathrm{C}_{23} \mathrm{H}_{28} \mathrm{BFNO}_{3}[\mathrm{M}+\mathrm{H}]^{+}$, 396.2; found, 396.4. ${ }^{1} \mathrm{H}$ NMR (400 MHz, DMSOd $\left.\mathrm{d}_{6}\right) \delta 9.81(\mathrm{~s}, 1 \mathrm{H}), 7.86(\mathrm{~d}, 2 \mathrm{H}), 7.37-7.30(\mathrm{~m}, 1 \mathrm{H}), 7.27-7.18(\mathrm{~m}, 3 \mathrm{H}), 2.35(\mathrm{~s}, 3 \mathrm{H}), 2.07-1.95$ (m, 1H), 1.32 (s, 12H), $1.06-0.99(\mathrm{~m}, 2 \mathrm{H}), 0.80-0.72(\mathrm{~m}, 2 \mathrm{H})$.

\section{3-Fluoro-4-formylbenzoic acid (S-6)}

A suspension of 3-fluoro-4-methylbenzoic acid (20.0 g, $130 \mathrm{mmol})$, N-bromosuccinimide (55.0 g, $309 \mathrm{mmol}$ ) and benzoyl peroxide (1.5 g, $6.2 \mathrm{mmol})$ in carbon tetrachloride $(250 \mathrm{~mL})$ was refluxed for $24 \mathrm{~h}$. After cooling to RT the mixture was filtered and the filtrate was concentrated under reduced pressure to afford crude $\mathbf{S}-\mathbf{5}$ as a yellow solid. The crude was used in the next step without further purification.

A solution of S-5 in EtOH ( $250 \mathrm{~mL}$ ) was warmed to $50^{\circ} \mathrm{C}$. A solution of silver nitrate (45.0 g, 265 mmol) in water $(60 \mathrm{~mL})$ was added dropwise over 20 min keeping the temperature at $50{ }^{\circ} \mathrm{C}$. The reaction mixture was stirred at $50{ }^{\circ} \mathrm{C}$ for $1 \mathrm{~h}$. After cooling to RT the mixture was poured onto aqueous $\mathrm{HCl}$ solution (1 M, $200 \mathrm{~mL}$ ). The suspension was filtered and the filtrate was concentrated under reduced pressure to remove most of the organic solvent. The remaining aqueous mixture was extracted with EtOAc. The organic layer was washed with brine, dried over $\mathrm{Na}_{2} \mathrm{SO}_{4}$, filtered and concentrated. The residue was triturated with diethylether/hexane $(1: 1,100 \mathrm{~mL})$. The resulting white solid was filtered off and dried in vacuo to afford S-6. Yield: 68 \% over two steps. [ES-MS] 
(ESI-): m/z calcd for $\mathrm{C}_{8} \mathrm{H}_{4} \mathrm{FO}_{3}[\mathrm{M}-\mathrm{H}]^{-}, 167.0$; found, 167.1. ${ }^{1} \mathrm{H}$ NMR (600 MHz, DMSO-d $\left.\mathrm{d}_{6}\right) \delta$ $13.66(\mathrm{~s}, 1 \mathrm{H}), 10.26(\mathrm{~s}, 1 \mathrm{H}), 7.97-7.92(\mathrm{~m}, 1 \mathrm{H}), 7.89$ (d, 1H), $7.81(\mathrm{~d}, 1 \mathrm{H})$.

\section{Methyl 3-fluoro-4-formylbenzoate (S-7)}

To a solution of S-6 (14.0 g, $83 \mathrm{mmol})$ in DMF (200 mL) was added sodium hydride (60 \%, 3.9 g, $98 \mathrm{mmol}$ ) in four portions within $30 \mathrm{~min}$. The thick slurry was stirred at RT for $30 \mathrm{~min}$. Methyl iodide (13.6 g, $96 \mathrm{mmol}$ ) was added dropwise within $30 \mathrm{~min}$. The reaction mixture was sitrred at RT overnight. The mixture was quenched with aqueous $\mathrm{HCl}$ solution and extracted with EtOAc (2x). The combined organic layers were washed with aqueous $\mathrm{NaHCO}_{3}$ solution (10\%), and brine, dried over $\mathrm{Na}_{2} \mathrm{SO}_{4}$, filtered and concentrated. The residue was dried in vacuo to afford crude $\mathbf{S}-\mathbf{7}$ as a red oil. The crude was used in the next step without further purification. Yield: $92 \%$.

\section{2-Fluoro-4-(methoxycarbonyl)benzoic acid (S-8)}

To a solution of S-7 (10.0 g, $54.9 \mathrm{mmol})$ and sulfamic acid (5.8 g, $59.7 \mathrm{mmol})$ in acetonitrile (50 $\mathrm{mL}$ ) and water $(50 \mathrm{~mL})$ was added a solution of sodium chlorite $(5.4 \mathrm{~g}, 59.7 \mathrm{mmol})$ in water (25 $\mathrm{mL}$ ) dropwise within $30 \mathrm{~min}$, so that the temperature was kept below $25^{\circ} \mathrm{C}$. The reaction mixture was stirred at $\mathrm{RT}$ for $1 \mathrm{~h}$ and was then poured onto a mixture of saturated aqueous $\mathrm{Na}_{2} \mathrm{SO}_{3}$ solution (200 mL) and aqueous $\mathrm{HCl}$ solution (2 M, $100 \mathrm{~mL}$ ) and extracted with EtOAc (2x). The combined organic layers were extracted with aqueous $\mathrm{Na}_{2} \mathrm{CO}_{3}$ solution $(10 \%)$. The aqueous layer was acidified to $\mathrm{pH}$ 2-3 with conc. $\mathrm{HCl}$, then extracted with EtOAc (2x). The combined organic layers were washed with brine, dried over $\mathrm{Na}_{2} \mathrm{SO}_{4}$, filtered and concentrated. The residue was triturated with diethylether/hexane $(1: 1,100 \mathrm{~mL})$. The white solid was filtered off and dried in vacuo to afford S-8. Yield: 46 \%. [ES-MS] (ESI-): m/z calcd for $\mathrm{C}_{9} \mathrm{H}_{6} \mathrm{FO}_{4}$ [M - H]', 197.0; found, 197.1. 
${ }^{1} \mathrm{H}$ NMR (600 MHz, DMSO-d 6 ) $\delta 13.66$ (s, br, 1H), 8.01 - 7.97 (m, 1H), 7.85 (dd, 1H), 7.77 (dd, 1H), 3.89 (s, 3H).

\section{2-Fluoro-4-(2-hydroxypropan-2-yl)benzoic acid (S-9)}

A solution of S-8 (4.0 g, $20.2 \mathrm{mmol})$ in THF (100 mL) was cooled to $0{ }^{\circ} \mathrm{C}$. Methylmagnesium bromide (3 $\mathrm{M}$ in diethylether, $27 \mathrm{~mL}, 81.0 \mathrm{mmol}$ ) was added over $1 \mathrm{~h}$ and stirring was continued at $0{ }^{\circ} \mathrm{C}$ for $4 \mathrm{~h}$. The mixture was quenched with saturated aqueous $\mathrm{NH}_{4} \mathrm{Cl}$ solution $(50 \mathrm{~mL})$, diluted with aqueous $\mathrm{HCl}(2 \mathrm{M})$ and extracted with EtOAc (2x). The combined organic layers were washed with brine, dried over $\mathrm{Na}_{2} \mathrm{SO}_{4}$, filtered and concentrated. The residue was purified by column chromatography ( $\mathrm{SiO}_{2}$; hexane/EtOAc gradient) to afford S-9 as a white solid. Yield: 67 \%. [ESMS] (ESI-): m/z calcd for $\mathrm{C}_{10} \mathrm{H}_{10} \mathrm{FO}_{3}\left[\mathrm{M}\right.$ - H]-, 197.1; found, 197.1. ${ }^{1} \mathrm{H}$ NMR (600 MHz, DMSOd6) $\delta 13.10(\mathrm{~s}, \mathrm{br}, 1 \mathrm{H}), 7.83-7.77(\mathrm{~m}, 1 \mathrm{H}), 7.38$ - $7.31(\mathrm{~m}, 2 \mathrm{H}), 5.28(\mathrm{~s}, 1 \mathrm{H}), 1.42(\mathrm{~s}, 6 \mathrm{H})$

\section{2-Fluoro-N-(5-fluoro-2-methyl-3-(4,4,5,5-tetramethyl-1,3,2-dioxaborolan-2-yl)phenyl)-4-(2-}

\section{hydroxypropan-2-yl)benzamide (S-10)}

A solution of S-9 (5.00 g, $25.2 \mathrm{mmol})$, HATU (13.43 g, $35.3 \mathrm{mmol})$ and DIPEA (13.2 mL, 9.78 g, $76.00 \mathrm{mmol}$ ) in DMF (63 mL) was stirred at RT for $25 \mathrm{~min}$, then 35 (6.33 g, $25.20 \mathrm{mmol}$ ) was added. The reaction mixture was stirred at $50{ }^{\circ} \mathrm{C}$ overnight, then concentrated under reduced pressure. The residue was taken up in EtOAc and washed with aqueous $\mathrm{Na}_{2} \mathrm{CO}_{3}$ solution (2x) and brine. The combined aqueous layers were back-extracted with EtOAc. The combined organic layers were dried over $\mathrm{Na}_{2} \mathrm{SO}_{4}$, filtered and concentrated. The residue was purified by column chromatography ( $\mathrm{SiO}_{2}$; (cyclohexane/DCM 1:1)/MTBE gradient) to afford $\mathbf{S - 1 0}$ as a beige solid. Yield: 71 \%. [ES-MS] (ESI+): m/z calcd for $\mathrm{C}_{23} \mathrm{H}_{29} \mathrm{BF}_{2} \mathrm{NO}_{4}[\mathrm{M}+\mathrm{H}]+$, 432.2; found, 432.4. ${ }^{1} \mathrm{H}$ 
NMR (400 MHz, DMSO-d 6 ) $\delta 9.77$ (s, 1H), 7.74 - 7.64 (m, 1H), 7.52 (d, 1H), 7.44 - 7.35 (m, 2H), 7.26 - 7.17 (m, 1H), 5.27 (s, 1H), 2.39 (s, 3H), 1.45 (s, 6H), 1.32 (s, 12H).

\section{Methyl 2,3-difluoro-4-methylbenzoate (S-12)}

To a solution of 2,3-difluoro-4-methylbenzoic acid (1000 g, $5.8 \mathrm{~mol})$ in $\mathrm{MeOH}$ (10 L) cooled to $10{ }^{\circ} \mathrm{C}$ was added thionylchloride $(507 \mathrm{~mL}, 6.96 \mathrm{~mol})$ slowly maintaining the temperature below $15{ }^{\circ} \mathrm{C}$. The reaction mixture was stirred at RT for $18 \mathrm{~h}$. It was then concentrated under reduced pressure. The residue was taken up in MTBE and washed with water, aqueous $\mathrm{Na}_{2} \mathrm{CO}_{3}$ solution, and brine. The organic layer was dried over $\mathrm{Na}_{2} \mathrm{SO}_{4}$, filtered and concentrated under reduced pressure to afford S-12 as a pale brown liquid. Yield: $97 \%$.

\section{2-(2,3-Difluoro-4-methylphenyl)propan-2-ol (S-13)}

A solution of S-12 (500 g, $2.69 \mathrm{~mol})$ in THF (4 L) was cooled to $0^{\circ} \mathrm{C}$. A solution of $\mathrm{MeMgBr}(3.0$ $\mathrm{M}$ in $\mathrm{Et}_{2} \mathrm{O}, 2.69 \mathrm{~L}, 8.07 \mathrm{~mol}$ ) was added slowly over $2 \mathrm{~h}$ keeping the temperature below $15^{\circ} \mathrm{C}$. The reaction mixture was stirred at $0{ }^{\circ} \mathrm{C}$ for $1 \mathrm{~h}$, then the temperature was allowed to warm to $\mathrm{RT}$ overnight. The mixture was quenched with saturated aqueous ammonium chloride solution and extracted with MTBE. The organic layer was dried over $\mathrm{Na}_{2} \mathrm{SO}_{4}$, filtered and concentrated. The crude (530 g) contained some ketone and was treated with a solution of $\mathrm{MeMgCl}$ (3 $\mathrm{M}$ in diethylether) in THF following the procedure above. Following the workup described above crude S-13 was obtained and used without further purification in the next step. Yield: quantitative. 


\section{2,3-Difluoro-4-(2-hydroxypropan-2-yl)benzoic acid (S-14)}

A suspension of S-13 $(50.0 \mathrm{~g}, 0.269 \mathrm{~mol})$ in water $(600 \mathrm{~mL})$ was warmed to $50{ }^{\circ} \mathrm{C}$ and $\mathrm{KMnO}_{4}$

(148.5 g, $0.939 \mathrm{~mol}$ ) was added in one portion. The mixture was stirred at $95{ }^{\circ} \mathrm{C}$ for $3 \mathrm{~h}$. After cooling to RT, the mixture was filtered through Celite and the filtrate was washed with MTBE. The aqueous layer was acidified with aqueous $\mathrm{HCl}(2 \mathrm{M})$ to $\mathrm{pH}$ 2-3 and a precipitate was formed, which was filtered off and dried to afford S-14. Yield: $35 \%$. [ES-MS] (ESI+): m/z calcd for $\mathrm{C}_{10} \mathrm{H}_{11} \mathrm{~F}_{2} \mathrm{O}_{3}[\mathrm{M}+\mathrm{H}]+$, 217.1; found, 217.1. ${ }^{1} \mathrm{H}$ NMR (400 MHz, DMSO-d $\left.\mathrm{d}_{6}\right) \delta 13.44$ (s, br, $1 \mathrm{H}$ ), $7.69-7.61$ (m, 1H), $7.54-7.46$ (m, 1H), 5.55 (s, 1H), 1.50 (s, 6H).

\section{2,3-Difluoro-N-(5-fluoro-2-methyl-3-(4,4,5,5-tetramethyl-1,3,2-dioxaborolan-2-yl)phenyl)-}

\section{4-(2-hydroxypropan-2-yl)benzamide (S-15)}

A solution of S-14 (0.878 g, $3.98 \mathrm{mmol})$, DIPEA (1.391 ml, $7.96 \mathrm{mmol})$ and HATU (2.12 g, 5.58 mmol) in DMF (20 mL) was stirred at RT for $25 \mathrm{~min} .35$ (1.00 g, $3.98 \mathrm{mmol}$ ) was added, and the reaction mixture was stirred at $60^{\circ} \mathrm{C}$ for $4 \mathrm{~h}$. It was then concentrated under reduced pressure. The residue was taken up in EtOAc and washed with aqueous $\mathrm{HCl}$ solution $(0.1 \mathrm{M})$, aqueous $\mathrm{Na}_{2} \mathrm{CO}_{3}$ solution (2 M), water and brine. The organic layer was dried over $\mathrm{Na}_{2} \mathrm{SO}_{4}$, filtered and concentrated. The crude was purified by column chromatography ( $\mathrm{SiO}_{2}$; (cyclohexane/DCM 4:1)/ EtOAc gradient). The product containing fractions were combined and evaporated. This residue was triturated with MTBE/pentane, filtered off, washed with pentane and dried in vacuo to afford S-15. Yield: $66 \%$. [ES-MS] (ESI+): m/z calcd for $\mathrm{C}_{23} \mathrm{H}_{28} \mathrm{BF}_{3} \mathrm{NO}_{4}[\mathrm{M}+\mathrm{H}]+$, 450.2; found, 450.2. ${ }^{1} \mathrm{H}$ NMR (400 MHz, DMSO-d $)$ ) $9.97(\mathrm{~s}, 1 \mathrm{H}), 7.59-7.45$ (m, 3H), 7.27 - 7.19 (m, 1H), 5.56 (s, 1H), 2.39 (s, 3H), 1.52 (s, 6H), 1.32 (s, 12H). 


\section{N-(3-(6-Aminopyrimidin-4-yl)-5-fluoro-2-methylphenyl)-4-cyclopropylbenzamide (9)}

To a solution of 4-amino-6-chloropyrimidine (50 mg, $0.386 \mathrm{mmol}$ ) and S-3 (183 mg, $0.463 \mathrm{mmol}$ ) in DME (7.5 mL) and water $(1.5 \mathrm{~mL})$ was added aqueous $\mathrm{NaHCO}_{3}$ solution $(1.2 \mathrm{M}, 1.5 \mathrm{~mL}, 1.800$ mmol). The mixture was purged for $10 \mathrm{~min}$, then $\mathrm{Pd}\left(\mathrm{PPh}_{3}\right)_{4}(13 \mathrm{mg}, 0.012 \mathrm{mmol})$ was added. The reaction mixture was stirred at $80{ }^{\circ} \mathrm{C}$ for $5 \mathrm{~h}$. The mixture was diluted with EtOAc and water. The organic layer was washed with water, dried over $\mathrm{Na}_{2} \mathrm{SO}_{4}$, filtered and concentrated. The residue was purified by column chromatography $\left(\mathrm{SiO}_{2}\right.$; heptane/EtOAc gradient) to afford 9. Yield: $39 \%$. [ES-MS] (ESI+): $\mathrm{m} / \mathrm{z}$ calcd for $\mathrm{C}_{21} \mathrm{H}_{20} \mathrm{FN}_{4} \mathrm{O}[\mathrm{M}+\mathrm{H}]+$, 363.2; found, 363.1. ${ }^{1} \mathrm{H}$ NMR (400 MHz, DMSO-d 6 ) $\delta 9.94(\mathrm{~s}, 1 \mathrm{H}), 8.44(\mathrm{~s}, 1 \mathrm{H}), 7.88(\mathrm{~d}, 2 \mathrm{H}), 7.37-7.30$ (m, 1H), $7.22(\mathrm{~d}, 2 \mathrm{H}), 7.15-7.05$ (m, 1H), 6.99 (s, 2H), $6.53-6.46$ (m, 1H), 2.14 (s, 3H), 2.06 - 1.96 (m, 1H), $1.08-0.99$ (m, 2H), $0.80-0.73(\mathrm{~m}, 2 \mathrm{H}) .{ }^{13} \mathrm{C}$ NMR (101 MHz, DMSO-d 6$) \delta 166.2,164.7,164.2,164.1,161.5,159.2$, 159.1, 149.2, 142.4, 142.2, 139.6, 139.5, 132.0, 128.7, 128.5, 128.4, 126.1, 114.6, 114.4, 114.1, 113.9, 105.3, 16.1, 15.7, 11.2. HRMS (ESI+): $\mathrm{m} / \mathrm{z}$ calcd for $\mathrm{C}_{21} \mathrm{H}_{20} \mathrm{FN}_{4} \mathrm{O}[\mathrm{M}+\mathrm{H}]+$, 363.16157; found, 363.16162 .

\section{2-(Dichloromethyl)-4,4,5,5-tetramethyl-1,3,2-dioxaborolane (S-18)}

To a solution of dichloromethane $(3.53 \mathrm{~mL}, 55.0 \mathrm{mmol})$ in THF $(100 \mathrm{~mL})$ at $-100{ }^{\circ} \mathrm{C}(\mathrm{EtOH} / \mathrm{liquid}$ $\mathrm{N}_{2}$ bath) was added $n \mathrm{BuLi}(2.5 \mathrm{M}$ in hexane) $(20.00 \mathrm{~mL}, 50.0 \mathrm{mmol})$ dropwise over a period of $45 \mathrm{~min}$. The resulting suspension was stirred for $30 \mathrm{~min}$ at $-100^{\circ} \mathrm{C}$. Then, trimethyl borate (6.13 $\mathrm{mL}, 55.0 \mathrm{mmol}$ ) was added in one portion and the reaction mixture was stirred for $30 \mathrm{~min}$ at -100 ${ }^{\circ} \mathrm{C}$. The mixture was quenched with aqueous $\mathrm{HCl}$ solution $(5 \mathrm{M}, 10 \mathrm{~mL})$ and stirring was continued at RT for $1 \mathrm{~h}$. The organic layer was separated and the aqueous layer was back-extracted with $\mathrm{Et}_{2} \mathrm{O}$. The combined organic layers were dried over $\mathrm{MgSO}_{4}$, filtered and concentrated to afford the 
crude boronic acid as a yellow viscous oil. To a solution of the crude in benzene (110 mL) was added pinacol (6.50 g, $55.0 \mathrm{mmol}$ ) and the reaction mixture was refluxed for $48 \mathrm{~h}$. The solvent was distilled off at $105{ }^{\circ} \mathrm{C}$ under normal pressure. The residue was purified by Kugelrohr distillation ( $\left.\mathrm{T}=25-90{ }^{\circ} \mathrm{C}, 0.008-0.012 \mathrm{mbar}\right)$ to afford $\mathbf{S - 1 8}$ as a colorless liquid. Yield $61 \% .{ }^{1} \mathrm{H}$ NMR (400 MHz, DMSO-d 6 ) $\delta 5.35$ (s, 1H), $1.13(\mathrm{~s}, 12 \mathrm{H})$.

tert-Butyl (E)-methyl(3-(4,4,5,5-tetramethyl-1,3,2-dioxaborolan-2-yl)allyl)carbamate (S-19) Anhydrous chromium(II) chloride $(9.88 \mathrm{~g}, 80.00 \mathrm{mmol})$ was suspended in THF (100 mL) in a dried flask under argon. A solution of tert-butyl methyl(2-oxoethyl)carbamate (2.9 g, $10.05 \mathrm{mmol}$, content $60 \%$ by NMR) and S-18 (4.24 g, $20.09 \mathrm{mmol})$ in THF (20 mL) was added in one portion to the above suspension. A solution of LiI $(5.38 \mathrm{~g}, 40.2 \mathrm{mmol})$ in THF $(20 \mathrm{~mL})$ was added dropwise. The flask was wrapped with aluminum foil and the reaction mixture was stirred vigorously at RT for $17 \mathrm{~h}$. The mixture was poured onto an ice/water mixture and extracted with cyclohexane (2x) and DCM (2x). The combined organic layers were dried over $\mathrm{MgSO}_{4}$, filtered and concentrated. The crude was purified by column chromatography $\left(\mathrm{SiO}_{2}\right.$; cyclohexane/EtOAc gradient) to afford S-19 as a colorless oil. Yield: $93 \%$. [ES-MS] (ESI+): m/z calcd for

$\mathrm{C}_{15} \mathrm{H}_{32} \mathrm{BN}_{2} \mathrm{O}_{4}\left[\mathrm{M}+\mathrm{NH}_{4}\right]^{+}$, 315.2; found, 315.2. ${ }^{1} \mathrm{H}$ NMR (400 MHz, Chloroform-d) $\delta 6.56-6.40$ (m, 1H), 5.48 (d, 1H), $3.97-3.77$ (m, 2H), 2.79 (s, 3H), 1.42 (s, 9H), 1.25 (s, 12H).

tert-Butyl (E)-methyl(4-(4,4,5,5-tetramethyl-1,3,2-dioxaborolan-2-yl)but-3-en-1-yl)carbamate (S-20)

Anhydrous chromium(II) chloride (14.70 g, $120 \mathrm{mmol}$ ) was suspended in THF (150 mL) in a dried flask. A solution of N-Boc-N-methyl-3-amino-propanal (2.80 g, $14.95 \mathrm{mmol})$ and S-18 (6.31 g, 
$29.9 \mathrm{mmol}$ ) in THF (30 mL) was added quickly to the suspension, followed by the dropwise addition of a solution of LiI (8.01 g, $59.8 \mathrm{mmol})$ in THF (30 mL). The flask was wrapped with aluminum foil and the reaction mixture was stirred vigorously at RT for $16 \mathrm{~h}$. The mixture was poured onto an ice/water mixture, extracted with heptane (2x) and $\mathrm{CH}_{2} \mathrm{Cl}_{2}(2 \mathrm{x})$. The combined organic layers were dried over $\mathrm{MgSO}_{4}$, filtered and concentrated. The residue was purified by column chromatography ( $\mathrm{SiO}_{2}$; heptane/EtOAc gradient) to afford $\mathbf{S - 2 0}$ as a light yellow solid. Yield: 47 \%. [ES-MS] (ESI+): m/z calcd for $\mathrm{C}_{12} \mathrm{H}_{23} \mathrm{BNO}_{4}[\mathrm{M}+\mathrm{H}-\mathrm{tBu}]^{+}$, 256.2; found, 256.0. ${ }^{1} \mathrm{H}$ NMR (400 MHz, Chloroform-d) $\delta 6.65-6.50$ (m, 1H), 5.47 (d, 1H), 3.36 - 3.21 (m, 2H), 2.82 (s, 3H), $2.42-2.29$ (m, 2H), 1.44 (s, 9H), 1.24 (s, 12H).

\section{6-Chloro-N-(2,4-dimethoxybenzyl)-5-iodopyrimidin-4-amine (S-22)}

To a solution of 4,6-dichloro-5-iodopyrimidine $(4.79 \mathrm{~g}, 17.43 \mathrm{mmol})$ in dioxane $(100 \mathrm{~mL})$ was added 2,4-dimethoxybenzylamine (2.88 mL, $19.17 \mathrm{mmol})$ followed by DIPEA (9.13 mL, 52.3 mmol). The reaction mixture was stirred at $60^{\circ} \mathrm{C}$ for $3 \mathrm{~h}$ and a white precipitate was formed. The mixture was concentrated under reduced pressure and the residue was taken up in EtOAc and washed with saturated aqueous $\mathrm{NaHCO}_{3}$ solution. The aqueous layer was back-extracted with EtOAc. The combined organic layers were washed with brine (2x), dried over $\mathrm{MgSO}_{4}$, filtered and concentrated. The residue was crystallized from EtOAc/heptane to afford a solid. The mother liquor was concentrated and the residue was crystallized again from EtOAc/heptane to provide a second batch of product. The two batches were combined to afford S-22 as an off-white solid. Yield 80 \%. [ES-MS] (ESI+): m/z calcd for $\mathrm{C}_{13} \mathrm{H}_{14} \mathrm{ClIN}_{3} \mathrm{O}_{2}[\mathrm{M}+\mathrm{H}]^{+}$, 406.0; found, 406.1. ${ }^{1} \mathrm{H}$ NMR (400 MHz, DMSO-d $\left.\mathrm{d}_{6}\right) \delta 8.16(\mathrm{~s}, 1 \mathrm{H}), 7.40(\mathrm{t}, 1 \mathrm{H}), 6.93(\mathrm{~d}, 1 \mathrm{H}), 6.57(\mathrm{~s}, 1 \mathrm{H}), 6.45(\mathrm{~d}, 1 \mathrm{H})$, $4.51(\mathrm{~d}, 2 \mathrm{H}), 3.82(\mathrm{~s}, 3 \mathrm{H}), 3.72(\mathrm{~s}, 3 \mathrm{H})$. 
tert-Butyl (E)-(3-(4-chloro-6-((2,4-dimethoxybenzyl)amino)pyrimidin-5-yl)allyl)(methyl)carbamate (S-23)

A mixture of S-19 (0.806 g, $2.71 \mathrm{mmol}), \mathbf{S}-22(1.00 \mathrm{~g}, 2.47 \mathrm{mmol})$ and aqueous $\mathrm{Na}_{2} \mathrm{CO}_{3}$ solution (1 M, $7.4 \mathrm{~mL}, 7.40 \mathrm{mmol})$ in DME $(14 \mathrm{~mL})$ and water $(2 \mathrm{~mL})$ was purged for $10 \mathrm{~min}$, then $\mathrm{PdCl}_{2}\left(\mathrm{PPh}_{3}\right)_{2}(0.087 \mathrm{~g}, 0.123 \mathrm{mmol})$ was added. The reaction mixture was stirred at $85{ }^{\circ} \mathrm{C}$ for $4 \mathrm{~h}$. It was then diluted with saturated aqueous $\mathrm{NaHCO}_{3}$ solution and extracted with EtOAc. The organic layer was washed with water and brine, dried over $\mathrm{MgSO}_{4}$, filtered and concentrated. The residue was purified by column chromatography ( $\mathrm{SiO}_{2}$; cyclohexane/EtOAc gradient) to afford $\mathbf{S}$ 23 as a yellow oil. Yield: 74 \%. [ES-MS] (ESI+): m/z calcd for $\mathrm{C}_{22} \mathrm{H}_{30} \mathrm{ClN}_{4} \mathrm{O}_{4}[\mathrm{M}+\mathrm{H}]^{+}, 449.2$; found, 449.2. ${ }^{1} \mathrm{H}$ NMR (400 MHz, DMSO-d 6 ) $\delta 8.14$ (s, 1H), 7.31 (s, br, 1H), $6.98(\mathrm{~d}, 1 \mathrm{H}), 6.55$ (d, 1H), 6.43 (dd, 1H), 6.26 (d, 1H), 6.14 - 5.98 (m, br, 1H), 4.48 (d, 2H), 4.02 - 3.93 (m, 2H), 3.80 (s, 3H), 3.72 (s, 3H), 2.82 (s, 3H), 1.39 (s, 9H).

tert-Butyl (E)-(3-(4-(3-(4-cyclopropylbenzamido)-5-fluoro-2-methylphenyl)-6-((2,4-dimethoxybenzyl)amino)pyrimidin-5-yl)allyl)(methyl)carbamate (S-24)

To a solution of S-23 (350 mg, $0.741 \mathrm{mmol})$ in DME (7 mL) and water (1 mL) was added S-3 (351 mg, $0.889 \mathrm{mmol}$ ) followed by aqueous $\mathrm{Na}_{2} \mathrm{CO}_{3}$ solution $(1 \mathrm{M}, 3.7 \mathrm{~mL}, 3.70 \mathrm{mmol})$. The mixture was purged for $10 \mathrm{~min}$, then $\mathrm{PdCl}_{2}\left(\mathrm{PPh}_{3}\right)_{2}(26.0 \mathrm{mg}, 0.037 \mathrm{mmol})$ was added. The reaction mixture was stirred at $85{ }^{\circ} \mathrm{C}$ for $4 \mathrm{~h}$. It was then diluted with saturated aqueous $\mathrm{NaHCO}_{3}$ solution and extracted with EtOAc. The organic layer was washed with water and brine, dried over $\mathrm{MgSO}_{4}$, filtered and concentrated. The crude was purified by column chromatography $\left(\mathrm{SiO}_{2}\right.$; cyclohexane/EtOAc gradient) to afford S-24 as a yellow foam. Yield: 62 \%. [ES-MS] (ESI+): m/z calcd for $\mathrm{C}_{39} \mathrm{H}_{45} \mathrm{FN}_{5} \mathrm{O}_{5}[\mathrm{M}+\mathrm{H}]^{+}$, 682.3; found, 682.3. ${ }^{1} \mathrm{H}$ NMR (400 MHz, DMSO-d 6$) \delta 9.80(\mathrm{~s}$, 
1H), 8.37 (s, 1H), 7.86 (d, 2H), 7.35 (d, 1H), 7.22 (d, 2H), 7.17 - 7.01 (m, 2H), 6.91 (dd, 1H), 6.57

(d, 1H), 6.47 (dd, 1H), $6.21-6.07$ (m, 1H), $5.61-5.46$ (m, 1H), 4.54 (s, br, 2H), 3.82 (s, 3H), $3.79-3.69$ (m, 5H), 2.49 (s, 3H, overlapping with DMSO), 2.05 - 1.97 (m, 1H), 1.93 (s, 3H), 1.32 (s, br, 9H), $1.06-1.00(\mathrm{~m}, 2 \mathrm{H}), 0.80-0.71(\mathrm{~m}, 2 \mathrm{H})$.

\section{(E)-N-(3-(6-Amino-5-(3-(methylamino)prop-1-en-1-yl)pyrimidin-4-yl)-5-fluoro-2-methyl-}

\section{phenyl)-4-cyclopropylbenzamide (S-25)}

To a solution of S-24 (200 mg, $0.279 \mathrm{mmol})$ in DCE $(4 \mathrm{~mL})$ was added TFA $(0.215 \mathrm{~mL}, 2.79$ mmol). The reaction mixture was stirred at $80^{\circ} \mathrm{C}$ for $36 \mathrm{~h}$. The mixture was poured onto saturated aqueous $\mathrm{NaHCO}_{3}$ solution and extracted with EtOAc (4x). The combined organic layers were washed with brine, dried over $\mathrm{MgSO}_{4}$, filtered and concentrated to afford S-25 as a beige solid. The crude was used in the next step without further purification. Yield: 76 \%. [ES-MS] (ESI+): $\mathrm{m} / \mathrm{z}$ calcd for $\mathrm{C}_{25} \mathrm{H}_{27} \mathrm{FN}_{5} \mathrm{O}[\mathrm{M}+\mathrm{H}]^{+}$, 432.2; found, 432.2.

\section{(E)-N-(3-(6-Amino-5-(3-(N-methylacrylamido)prop-1-en-1-yl)pyrimidin-4-yl)-5-fluoro-2-}

\section{methylphenyl)-4-cyclopropylbenzamide (10)}

A stock solution of acryloyl chloride $(0.070 \mathrm{~mL}, 78 \mathrm{mg}, 0.863 \mathrm{mmol})$ in DCM $(1.0 \mathrm{~mL})$ was prepared. To a solution of S-25 (107 mg, $0.211 \mathrm{mmol})$ and triethylamine $(0.088 \mathrm{~mL}, 0.632 \mathrm{mmol})$ in DCM $(3.0 \mathrm{~mL})$ at $-10^{\circ} \mathrm{C}$ was added acryloyl stock solution $(0.100 \mathrm{~mL})$ and the reaction mixture was stirred at RT for $30 \mathrm{~min}$. Another portion of acryloyl chloride stock solution $(0.100 \mathrm{~mL})$ was added at $-10{ }^{\circ} \mathrm{C}$ and stirring was continued at RT for $1 \mathrm{~h}$. The mixture was quenched with saturated aqueous $\mathrm{NH}_{4} \mathrm{Cl}$ solution and extracted with EtOAc. The organic layer was washed with brine, dried over $\mathrm{MgSO}_{4}$, filtered and concentrated. The crude was purified by column chromatography 
( $\mathrm{SiO}_{2}$; (DCM with $2 \%$ ammonia)/MeOH gradient) to afford 10 as a beige solid. Yield: $22 \%$. [ESMS] (ESI+): $\mathrm{m} / \mathrm{z}$ calcd for $\mathrm{C}_{28} \mathrm{H}_{29} \mathrm{FN}_{5} \mathrm{O}_{2}[\mathrm{M}+\mathrm{H}]^{+}$, 486.2; found 486.2. ${ }^{1} \mathrm{H}$ NMR (400 MHz, DMSO-d $\left.\mathrm{d}_{6}\right)$ rotamers $\delta 9.84$ and $9.80(2 \mathrm{~s}$, total $1 \mathrm{H}), 8.32(\mathrm{~s}, 1 \mathrm{H}), 7.87(\mathrm{~d}, 2 \mathrm{H}), 7.35-7.27(\mathrm{~m}, 1 \mathrm{H})$, 7.22 (d, 2H), $7.02-6.83$ (m, 3H), $6.68-6.46$ (m, 1H), 6.15 - 5.91 (m, 2H), 5.66 - 5.52 and 5.51 -5.39 (2m, total $2 \mathrm{H}), 4.00-3.87$ (m, 2H), 2.71 and 2.67 (2s, total 3H), $2.05-1.96(\mathrm{~m}, 1 \mathrm{H}), 1.90$ and 1.89 (2s, total 3H), $1.07-0.99$ (m, 2H), $0.80-0.72$ (m, 2H). ${ }^{13} \mathrm{C}$ NMR (126 MHz, DMSO$\mathrm{d}_{6}$ ) rotamers $\delta 165.35,165.19,165.16,164.97,161.37,161.30,161.18,160.25,160.19,158.34$, 158.27, 156.03, 155.96, 148.24, 141.33, 141.26, 141.15, 141.08, 138.32, 138.24, 138.19, 131.94, 131.41, 131.10, 128.48, 128.27, 127.74, 126.99, 126.97, 125.14, 123.87, 122.23, 112.70, 112.68, 112.52, 112.49, 112.18, 111.91, 51.00, 48.85, 34.06, 33.21, 15.15, 14.17, 10.18. HRMS (ESI+): $\mathrm{m} / \mathrm{z}$ calcd for $\mathrm{C}_{28} \mathrm{H}_{29} \mathrm{FN}_{5} \mathrm{O}_{2}[\mathrm{M}+\mathrm{H}]+$, 486.22998; found, 486.23001.

tert-Butyl (E)-(4-(4-chloro-6-((2,4-dimethoxybenzyl)amino)pyrimidin-5-yl)but-3-en-1-yl)(methyl)carbamate (S-26)

The title compound S-26 was obtained as a yellow oil following the procedure described for S-23 substituting S-20 for S-19. Yield: $70 \%$. [ES-MS] (ESI+): $\mathrm{m} / \mathrm{z}$ calcd for $\mathrm{C}_{23} \mathrm{H}_{32} \mathrm{ClN}_{4} \mathrm{O}_{4}[\mathrm{M}+\mathrm{H}]^{+}$, 463.2; found, 463.2. ${ }^{1} \mathrm{H}$ NMR (400 MHz, DMSO-d 6 ) rotamers $\delta 8.11(\mathrm{~s}, 1 \mathrm{H}), 7.45-7.27(\mathrm{~m}, 1 \mathrm{H})$, $7.01-6.93$ (m, 1H), 6.55 (s, 1H), $6.47-6.40(\mathrm{~m}, 1 \mathrm{H}), 6.27-6.19(\mathrm{~m}, 1 \mathrm{H}), 6.19-6.07$ (m, 1H), 4.49 (d, 2H), 3.81 (s, 3H), 3.72 (s, 3H), 2.82 (s, br, 3H), 2.48 - 2.38 (m, 2H), 1.42 - 1.37 (m, 2H), $1.34(\mathrm{~s}, 9 \mathrm{H})$. 
tert-Butyl (E)-(4-(4-(3-(4-cyclopropylbenzamido)-5-fluoro-2-methylphenyl)-6-((2,4-dimethoxybenzyl)amino)pyrimidin-5-yl)but-3-en-1-yl)(methyl)carbamate (S-27)

The title compound S-27 was obtained as a beige foam following the procedure described for S-24 substituting S-26 for S-23. Yield: 67 \%. [ES-MS] (ESI+): m/z calcd for $\mathrm{C}_{40} \mathrm{H}_{47} \mathrm{FN}_{5} \mathrm{O}_{5}[\mathrm{M}+\mathrm{H}]^{+}$, 696.4; found, 696.4. ${ }^{1} \mathrm{H}$ NMR (400 MHz, DMSO-d $)$ rotamers $\delta 9.87(\mathrm{~s}, 1 \mathrm{H}), 8.34(\mathrm{~s}, 1 \mathrm{H}), 7.87$ (d, 2H), $7.34-7.27$ (m, 1H), 7.25 - 7.09 (m, 3H), 7.06 (d, 1H), 6.89 (d, 1H), 6.57 (d, 1H), 6.47 (d, 1H), 6.15 - 5.99 (m, 1H), 5.73 - 5.48 (m, br, 1H), 4.54 (s, br, 2H), 3.83 (s, 3H), 3.74 (s, 3H), 3.15 - 2.98 (m, br, 2H), $2.71-2.61(\mathrm{~m}, 3 \mathrm{H}), 2.24-2.14(\mathrm{~m}, 2 \mathrm{H}), 2.06-1.96(\mathrm{~m}, 1 \mathrm{H}), 1.91$ (s, 3H), $1.31(\mathrm{~s}, 9 \mathrm{H}), 1.06-1.00(\mathrm{~m}, 2 \mathrm{H}), 0.80-0.72(\mathrm{~m}, 2 \mathrm{H})$.

\section{(E)-N-(3-(6-Amino-5-(4-(methylamino)but-1-en-1-yl)pyrimidin-4-yl)-5-fluoro-2-methyl-} phenyl)-4-cyclopropylbenzamide (S-28)

The title compound S-28 was obtained as a beige solid following the procedure described for $\mathbf{S - 2 5}$ substituting S-27 for S-24. Yield: 75 \%. [ES-MS] (ESI+): m/z calcd for $\mathrm{C}_{26} \mathrm{H}_{29} \mathrm{FN}_{5} \mathrm{O}[\mathrm{M}+\mathrm{H}]^{+}$, 446.2; found, 446.2. ${ }^{1} \mathrm{H}$ NMR (400 MHz, DMSO-d 6 ) $\delta 9.88(\mathrm{~s}, 1 \mathrm{H}), 8.29(\mathrm{~s}, 1 \mathrm{H}), 7.92$ - 7.81 (m, 2H), $7.35-7.26(\mathrm{~m}, 1 \mathrm{H}), 7.26-7.17(\mathrm{~m}, 2 \mathrm{H}), 6.97-6.77(\mathrm{~m}, 3 \mathrm{H}), 5.99(\mathrm{~d}, 1 \mathrm{H}), 5.49(\mathrm{dt}, 1 \mathrm{H})$, $2.36(\mathrm{t}, 2 \mathrm{H}), 2.19(\mathrm{~s}, 3 \mathrm{H}), 2.15-2.06(\mathrm{~m}, 2 \mathrm{H}), 2.05-1.96(\mathrm{~m}, 1 \mathrm{H}), 1.92(\mathrm{~s}, 3 \mathrm{H}), 1.08-0.99(\mathrm{~m}$, 2H), $0.80-0.72(\mathrm{~m}, 2 \mathrm{H}), 1$ exchangeable proton not observed.

(E)-N-(3-(6-Amino-5-(4-(N-methylacrylamido)but-1-en-1-yl)pyrimidin-4-yl)-5-fluoro-2methylphenyl)-4-cyclopropylbenzamide (11)

The title compound $\mathbf{1 1}$ was obtained as a white solid following the procedure described for $\mathbf{1 0}$ substituting S-28 for S-25. Yield: 45 \%. [ES-MS] (ESI+): m/z calcd for $\mathrm{C}_{29} \mathrm{H}_{31} \mathrm{FN}_{5} \mathrm{O}_{2}[\mathrm{M}+\mathrm{H}]^{+}$, 
500.3; found, 500.2. ${ }^{1} \mathrm{H}$ NMR (400 MHz, DMSO-d 6 ) rotamers $\delta 9.92$ and 9.89 (2s, total $1 \mathrm{H}$ ), 8.29 (d, 1H), $7.95-7.83$ (m, 2H), $7.34-7.26$ (m, 1H), 7.22 (d, 2H), $7.00-6.79$ (m, 3H), $6.77-6.64$ (m, $1 \mathrm{H}), 6.14-6.01$ and $5.98-5.90(2 \mathrm{~m}$, total $2 \mathrm{H}), 5.69-5.57$ and $5.55-5.44(2 \mathrm{~m}$, total $2 \mathrm{H})$, $3.32-3.27$ (m, 2H, overalapping with water peak), 2.94 and 2.77 (2s, total 3H), $2.26-2.16$ (m, 2H), $2.06-1.97$ (m, 1H), 1.89 and 1.88 (2s, total 3H), $1.07-0.99$ (m, 2H), $0.80-0.73$ (m, 2H).

N-(3-(5-((1-Acryloylpyrrolidin-3-yl)oxy)-6-aminopyrimidin-4-yl)-5-fluoro-2-methylphenyl)4-cyclopropylbenzamide (12)

Step 1 : tert-Butyl 3-((4-amino-6-chloropyrimidin-5-yl)oxy)pyrrolidine-1-carboxylate (S-29) A suspension of 41 (539 mg, $3.52 \mathrm{mmol}), \mathrm{K}_{2} \mathrm{CO}_{3}(1459 \mathrm{mg}, 10.55 \mathrm{mmol})$ and N-Boc-3bromopyrrolidine (1760 mg, $7.04 \mathrm{mmol})$ in DMF $(10 \mathrm{~mL})$ was heated at $100{ }^{\circ} \mathrm{C}$ for $1 \mathrm{~h}$ under microwave irradiation. The mixture was diluted with saturated aqueous $\mathrm{NaHCO}_{3}$ solution and extracted with EtOAc. The organic layer was wahsed with water and brine, dried over $\mathrm{MgSO}_{4}$, filtered and concentrated. The residue was purified by column chromatography $\left(\mathrm{SiO}_{2}\right.$; DCM/MeOH gradient to afford S-29 as a white solid after trituration with diethylether. Yield: 70 \%. [ES-MS] (ESI+): $\mathrm{m} / \mathrm{z}$ calcd for $\mathrm{C}_{13} \mathrm{H}_{20} \mathrm{ClN}_{4} \mathrm{O}_{3}[\mathrm{M}+\mathrm{H}]+$, 315.1.1; found, 315.2.

Step 2 : tert-Butyl 3-((4-amino-6-(3-(4-cyclopropylbenzamido)-5-fluoro-2-methylphenyl)pyrimidin-5-yl)oxy)pyrrolidine-1-carboxylate (S-30)

To a solution of S-29 $(800 \mathrm{mg}, 2.41 \mathrm{mmol})$ in DME $(10 \mathrm{~mL})$ and water $(1.4 \mathrm{~mL})$ was added S-3 (1145 mg, $2.90 \mathrm{mmol}$ ) followed by aqueous $\mathrm{Na}_{2} \mathrm{CO}_{3}$ solution (1 M, $\left.7.2 \mathrm{~mL}, 7.24 \mathrm{mmol}\right)$. After purging for $10 \mathrm{~min}, \mathrm{PdCl}_{2}\left(\mathrm{PPh}_{3}\right)_{2}(85 \mathrm{mg}, 0.121 \mathrm{mmol})$ was added and the reaction mixture was stirred at $85{ }^{\circ} \mathrm{C}$ for $12 \mathrm{~h}$. More aqueous $\mathrm{Na}_{2} \mathrm{CO}_{3}$ solution ( $1 \mathrm{M}, 3.0 \mathrm{~mL}, 3.00 \mathrm{mmol}$ ) was added and stirring was continued at $85{ }^{\circ} \mathrm{C}$ for an additional $12 \mathrm{~h}$. The mixture was diluted with saturated 
aqueous $\mathrm{NaHCO}_{3}$ solution and extracted with EtOAc. The organic layer was washed with water and brine, dried over $\mathrm{MgSO}_{4}$, filtered and concentrated. The residue was purified by column chromatography ( $\mathrm{SiO}_{2}$; DCM/MeOH gradient) to afford $\mathbf{S}-30$ as a beige solid. Yield $46 \%$. [ESMS] (ESI+): m/z calcd for $\mathrm{C}_{30} \mathrm{H}_{35} \mathrm{FN}_{5} \mathrm{O}_{4}[\mathrm{M}+\mathrm{H}]^{+}$, 548.3; found, 548.4.

Step 3 : N-(3-(6-Amino-5-(pyrrolidin-3-yloxy)pyrimidin-4-yl)-5-fluoro-2-methylphenyl)-4cyclopropylbenzamide (S-31)

To a solution of S-30 (200 mg, $0.347 \mathrm{mmol})$ in DCM (4 mL) was added TFA (0.267 mL, 3.47 mmol). The rection mixture was stirred at RT for $4 \mathrm{~h}$, then loaded on a PL- $\mathrm{HCO}_{3}$ MP SPE cartridge. The amine was eluted with $\mathrm{MeOH}$. The product containing fractions were concentrated to afford crude S-31 as free base. Yield: $87 \%$. [ES-MS] (ESI+): m/z calcd for $\mathrm{C}_{25} \mathrm{H}_{27} \mathrm{FN}_{5} \mathrm{O}_{2}[\mathrm{M}+$ $\mathrm{H}]^{+}$, 448.2; found, 448.3 .

Step $\quad 4: \quad$ N-(3-(5-((1-Acryloylpyrrolidin-3-yl)oxy)-6-aminopyrimidin-4-yl)-5-fluoro-2methylphenyl)-4-cyclopropylbenzamide (12)

A stock solution of acryloyl chloride $(0.100 \mathrm{~mL}, 112 \mathrm{mg}, 1.24 \mathrm{mmol})$ in DCM (1.0 mL) was prepared. To a solution of S-31 (140 mg, $0.282 \mathrm{mmol})$ and triethylamine $(0.118 \mathrm{~mL}, 0.845 \mathrm{mmol})$ in DCM (4 mL) at $-10^{\circ} \mathrm{C}$ was added acryloyl chloride stock solution $(0.100 \mathrm{~mL})$ and the reaction mixture was stirred at RT for $30 \mathrm{~min}$. Another portion of stock solution $(0.100 \mathrm{~mL})$ was added at $-10{ }^{\circ} \mathrm{C}$ and stirring was continued at RT for $30 \mathrm{~min}$. The mixture was quenched with saturated aqueous $\mathrm{NH}_{4} \mathrm{Cl}$ solution and extracted with EtOAc. The organic layer was washed with brine, dried over $\mathrm{MgSO}_{4}$, filtered and concentrated. The residue was purified by SFC to afford $\mathbf{1 2}$ as a white solid. Yield: $37 \%$. [ES-MS] (ESI+): m/z calcd for $\mathrm{C}_{28} \mathrm{H}_{29} \mathrm{FN}_{5} \mathrm{O}_{3}[\mathrm{M}+\mathrm{H}]^{+}$, 502.2; found, 502.2. ${ }^{1} \mathrm{H}$ NMR (400 MHz, DMSO-d 6 ) rotamers $\delta 9.93$ and $9.88(2 \mathrm{~s}$, total $1 \mathrm{H}), 8.23(\mathrm{~s}, 1 \mathrm{H}), 7.94$ - 7.84 (m, 2H), $7.40-7.31$ (m, 1H), 7.23 (d, 2H), $7.11-6.88$ (m, 3H), $6.46-6.34$ (m, 1H), 6.12 
- 6.00 (m, 1H), $5.65-5.54$ (m, 1H), $4.41-4.28$ (m, 1H), $3.54-3.36(\mathrm{~m}, 2 \mathrm{H}), 3.26-3.13(\mathrm{~m}$, 2H), $2.07-1.97$ (m, 4H), $1.88-1.69(\mathrm{~m}, 2 \mathrm{H}), 1.08-1.01(\mathrm{~m}, 2 \mathrm{H}), 0.81-0.73(\mathrm{~m}, 2 \mathrm{H}) .{ }^{13} \mathrm{C}$ NMR (126 MHz, DMSO-d 6 ) rotamers $\delta 165.24,163.16,163.05,160.17,160.08,159.05,159.04,158.25$, 158.16, 154.24, 153.93, 153.00, 148.25, 138.63, 138.56, 138.49, 138.39, 138.30, 138.23, 138.15, 134.15, 133.53, 131.12, 131.09, 129.42, 129.36, 128.00, 127.77, 126.47, 126.21, 125.14, 113.63, 113.56, 113.46, 113.39, 113.28, 81.05, 78.55, 51.29, 50.74, 43.60, 43.24, 31.27, 29.80, 15.16, 14.58, 14.53, 10.19. HRMS (ESI+): $\mathrm{m} / \mathrm{z}$ calcd for $\mathrm{C}_{28} \mathrm{H}_{29} \mathrm{FN}_{5} \mathrm{O}_{3}[\mathrm{M}+\mathrm{H}]+$, 502.22489; found, 502.22488.

tert-Butyl 3-((4-amino-6-chloropyrimidin-5-yl)oxy)azetidine-1-carboxylate (S-32)

To a solution of N-Boc-3-iodoazetidine (6.84 g, $24.16 \mathrm{mmol}$ ) in DMF (37 mL) was added 41 (2.00 g, $13.74 \mathrm{mmol})$ followed by $\mathrm{K}_{2} \mathrm{CO}_{3}(5.70 \mathrm{~g}, 41.2 \mathrm{mmol})$. The reaction mixture was stirred at 100 ${ }^{\circ} \mathrm{C}$ for $16 \mathrm{~h}$. The mixture was diluted with EtOAc and washed with saturated $\mathrm{NaHCO}_{3}$ solution. The aqueous layer was back-extracted with EtOAc. The combined organic layers were washed with water (2x) and brine (2x), dried over $\mathrm{MgSO}_{4}$, filtered and concentrated. The crude was purified by column chromatography $\left(\mathrm{SiO}_{2} ; \mathrm{CH}_{2} \mathrm{Cl}_{2} / \mathrm{MeOH}\right.$ gradient). The product containing fractions were combined and evaporated. This residue was triturated with cyclohexane. The solid was filtered off, washed with cyclohexane and dried in vacuo to afford S-32. Yield: $56 \%$. [ESMS] (ESI+): $\mathrm{m} / \mathrm{z}$ calcd for $\mathrm{C}_{12} \mathrm{H}_{18} \mathrm{ClN}_{4} \mathrm{O}_{3}[\mathrm{M}+\mathrm{H}]^{+}$, 301.1; found, 301.0. ${ }^{1} \mathrm{H}$ NMR (400 MHz, DMSO-d $\left.{ }_{6}\right) \delta 7.98(\mathrm{~s}, 1 \mathrm{H}), 7.34$ (s, br, 2H), $4.89-4.75$ (m, 1H), $4.17-4.00$ (m, 4H), 1.38 (s, 9H). 
tert-Butyl 3-((4-amino-6-(3-(4-cyclopropylbenzamido)-5-fluoro-2-methylphenyl)pyrimidin5-yl)oxy)azetidine-1-carboxylate (S-33)

To a solution of S-32 (650 mg, $2.053 \mathrm{mmol})$ in DME (8.0 mL) and water (1.14 mL) was added S3 (974 mg, $2.464 \mathrm{mmol}$ ) followed by aqueous $\mathrm{Na}_{2} \mathrm{CO}_{3}$ solution (1 M, $\left.6.16 \mathrm{~mL}, 6.16 \mathrm{mmol}\right)$. After purging with argon for $10 \mathrm{~min}, \mathrm{PdCl}_{2}\left(\mathrm{PPh}_{3}\right)_{2}(72.1 \mathrm{mg}, 0.103 \mathrm{mmol})$ was added and the reaction mixture was stirred at $85{ }^{\circ} \mathrm{C}$ for $12 \mathrm{~h}$. More aqueous $\mathrm{Na}_{2} \mathrm{CO}_{3}$ solution ( $1 \mathrm{M}, 3.0 \mathrm{~mL}, 3.00 \mathrm{mmol}$ ) was added and stirring was continued $85^{\circ} \mathrm{C}$ for another $4 \mathrm{~h}$. The mixture was partitioned between saturated aqueous $\mathrm{NaHCO}_{3}$ solution and EtOAc. The resulting solid was fitered off to afford a first batch of S-33. The organic layer of the filtrate was washed with water and brine, dried over $\mathrm{MgSO}_{4}$, filtered and concentrated. The residue was purified by column chromatography $\left(\mathrm{SiO}_{2}\right.$; DCM/MeOH gradient). The product containing fractions were combined and concentrated. The residue was taken up in $\mathrm{CH}_{2} \mathrm{Cl}_{2}$, the resulting solid was filtered off and dried in vacuo to afford a second batch of S-33. The two batches were combined to provide S-33 as a white solid. Yield: 62 \%. [ES-MS] (ESI+): m/z calcd for $\mathrm{C}_{29} \mathrm{H}_{33} \mathrm{FN}_{5} \mathrm{O}_{4}[\mathrm{M}+\mathrm{H}]{ }^{+}$, 534.3; found, 534.2. ${ }^{1} \mathrm{H}$ NMR (400 MHz, DMSO-d $) \delta 9.95$ (s, 1H), 8.19 (s, 1H), 7.88 (d, 2H), $7.44-7.36$ (m, 1H), 7.23 (d, 2H), 7.15 - 6.99 (m, 3H), 4.30 - 4.21 (m, 1H), 3.75 - 3.58 (m, 4H), 2.06 - 1.95 (m, 1H) overlapping with 2.00 (s, 3H), 1.32 (s, 9H), $1.08-1.00$ (m, 2H), $0.80-0.73$ (m, 2H).

\section{N-(3-(6-Amino-5-(azetidin-3-yloxy)pyrimidin-4-yl)-5-fluoro-2-methylphenyl)-4- cyclopropyl-benzamide (S-34)}

To a solution of S-33 (144 mg, $0.270 \mathrm{mmol})$ in DCM (3 mL) was added TFA (0.208 mL, 2.70 mmol). The reaction mixture was stirred at RT for $6 \mathrm{~h}$. The TFA was removed by solid phase extraction using a $\mathrm{PL}-\mathrm{HCO}_{3}$ MP SPE cartridge to afford S-34 as free base. Yield: 88 \%. The crude 
was used without further purification. [ES-MS] $(\mathrm{ESI}+)$ : $\mathrm{m} / \mathrm{z}$ calcd for $\mathrm{C}_{24} \mathrm{H}_{25} \mathrm{FN}_{5} \mathrm{O}_{2}[\mathrm{M}+\mathrm{H}]^{+}$, 434.2; found, 434.2.

\section{N-(3-(5-((1-Ascryloylazetidin-3-yl)oxy)-6-aminopyrimidin-4-yl)-5-fluoro-2-methylphenyl)- 4-cyclopropylbenzamide (13)}

A stock solution of acryloyl chloride $(77 \mu \mathrm{L}, 0.952 \mathrm{mmol})$ in DCM $(1 \mathrm{~mL})$ was prepared. To a solution of S-34 (115 mg, $0.239 \mathrm{mmol})$ and triethylamine $(0.100 \mathrm{~mL}, 0.716 \mathrm{mmol})$ in DCM (3 $\mathrm{mL})$ at $-10{ }^{\circ} \mathrm{C}$ was added dropwise acryloyl chloride stock solution $(0.100 \mathrm{~mL})$. The reaction mixture was stirred at RT for $15 \mathrm{~min}$. Two more portions of stock solution ( $0.100 \mathrm{~mL}$ each) were added at $-10{ }^{\circ} \mathrm{C}$ within $45 \mathrm{~min}$ and stirring continued at RT for $30 \mathrm{~min}$. The mixture was quenched with saturated aqueous $\mathrm{NH}_{4} \mathrm{Cl}$ solution and extracted with EtOAc. The organic layer was washed with brine, dried over $\mathrm{MgSO}_{4}$, filtered and concentrated. The residue was purified by column chromatography ( $\mathrm{SiO}_{2}$; (DCM with $2 \%$ ammonia)/MeOH gradient) to afford $\mathbf{1 3}$ as a white solid. Yield: 49 \%. [ES-MS] (ESI+): m/z calcd for $\mathrm{C}_{27} \mathrm{H}_{27} \mathrm{FN}_{5} \mathrm{O}_{3}[\mathrm{M}+\mathrm{H}]^{+}$, 488.2; found, 488.1. ${ }^{1} \mathrm{H}$ NMR (400 MHz, DMSO-d $\left.{ }_{6}\right) \delta 9.98(\mathrm{~s}, 1 \mathrm{H}), 8.20(\mathrm{~s}, 1 \mathrm{H}), 7.88(\mathrm{~d}, 2 \mathrm{H}), 7.38(\mathrm{dd}, 1 \mathrm{H}), 7.23(\mathrm{~d}, 2 \mathrm{H}), 7.12$ (s, br, 2H), 7.05 (dd, 1H), 6.17 (dd, 1H), 6.02 (dd, 1H), 5.62 (dd, 1H), 4.39 - 4.29 (m, 1H), 4.11 $3.95(\mathrm{~m}, 2 \mathrm{H}), 3.81-3.70(\mathrm{~m}, 2 \mathrm{H}), 2.07-1.96(\mathrm{~m}, 1 \mathrm{H})$ overlapping with $2.00(\mathrm{~s}, 3 \mathrm{H}), 1.08-1.00$ (m, 2H), $0.80-0.73$ (m, 2H). ${ }^{13} \mathrm{C}$ NMR (101 MHz, DMSO-d $) \delta$ 165.30, 164.39, 160.47, 158.51, 158.07, 153.13, 152.92, 148.29, 138.49, 138.40, 138.38, 135.34, 131.01, 128.03, 128.00, 127.77, 126.90, 126.49, 125.15, 113.75, 113.53, 113.41, 113.20, 71.14, 57.31, 55.17, 15.16, 14.36, 10.19 . HRMS (ESI+): m/z calcd for $\mathrm{C}_{27} \mathrm{H}_{27} \mathrm{FN}_{5} \mathrm{O}_{3}[\mathrm{M}+\mathrm{H}]+$, 488.20924; found, 488.20926. 
tert-Butyl 3-((4-amino-6-(3-(4-cyclopropyl-2-fluorobenzamido)-5-fluoro-2-methylphenyl)pyrimidin-5-yl)oxy)azetidine-1-carboxylate (S-35)

To a solution of S-32 (500 mg, $1.663 \mathrm{mmol})$ in DME (11.8 mL) and water $(1.7 \mathrm{~mL})$ was added 38 (790 mg, $1.912 \mathrm{mmol}$ ) followed by aqueous $\mathrm{Na}_{2} \mathrm{CO}_{3}$ solution (1 M, $\left.4.99 \mathrm{~mL}, 4.99 \mathrm{mmol}\right)$. After purging with argon for $5 \mathrm{~min}, \mathrm{PdCl}_{2}\left(\mathrm{PPh}_{3}\right)_{2}$ (58.3 $\left.\mathrm{mg}, 0.083 \mathrm{mmol}\right)$ was added and the reaction mixture was stirred at $85{ }^{\circ} \mathrm{C}$ for $4 \mathrm{~h}$. More 38 (170 mg, $\left.0.411 \mathrm{mmol}\right)$ and $\mathrm{PdCl}_{2}\left(\mathrm{PPh}_{3}\right)_{2}(20 \mathrm{mg}$, $0.028 \mathrm{mmol}$ ) were added and stirring was continued at $85^{\circ} \mathrm{C}$ for an additional $1.5 \mathrm{~h}$. The mixture was diluted with EtOAc and washed with saturated aqueous $\mathrm{NaHCO}_{3}$ solution, water and brine. The organic layer was dried over $\mathrm{MgSO}_{4}$, filtered and concentrated. The residue was purified by column chromatography ( $\mathrm{SiO}_{2}$; $\mathrm{cHex} /$ EtOAc gradient). The product containing fractions were combined and concentrated. The residue was triturated with EtOAc/cyclohexane. The resulting solid was collected by filtration to afford S-35. Yield: $45 \%$. [ES-MS] (ESI+): m/z calcd for $\mathrm{C}_{29} \mathrm{H}_{32} \mathrm{~F}_{2} \mathrm{~N}_{5} \mathrm{O}_{4}[\mathrm{M}+\mathrm{H}]^{+}$, 552.2; found, 552.2. ${ }^{1} \mathrm{H}$ NMR (400 MHz, DMSO-d $\left.{ }_{6}\right) \delta 9.85(\mathrm{~s}, 1 \mathrm{H}), 8.19$ (s, 1H), $7.70-7.61$ (m, 1H), $7.61-7.51$ (m, 1H), 7.13 - 6.98 (m, 5H), $4.30-4.20$ (m, 1H), 3.63 (s, br, 4H), $2.07-1.97$ (m, 1H) overlapping with 2.03 (s, 3H), 1.30 (s, 9H), $1.11-0.99$ (m, 2H), $0.85-0.74(\mathrm{~m}, 2 \mathrm{H})$.

\section{N-(3-(6-Amino-5-(azetidin-3-yloxy)pyrimidin-4-yl)-5-fluoro-2-methylphenyl)-4-cyclo- propyl-2-fluorobenzamide (S-36)}

To a suspension of S-35 (400 mg, $0.725 \mathrm{mmol})$ in $\mathrm{CH}_{2} \mathrm{Cl}_{2}(9.7 \mathrm{~mL})$ at $0{ }^{\circ} \mathrm{C}$ was added TFA $(0.559$ $\mathrm{mL}, 7.25 \mathrm{mmol}$ ) dropwise. The resulting solution was stirred at RT for $23 \mathrm{~h}$. PL-HCO 3 MP-resin (5.0 g, loading $2.14 \mathrm{mmol} / \mathrm{g}$ ) was suspended in $\mathrm{CH}_{2} \mathrm{Cl}_{2}(20 \mathrm{~mL})$ and the reaction mixture was added slowly. The mixture was stirred at RT for 15 min and filtered through Celite. The filter cake 
was washed with $\mathrm{MeOH}$. The combined filtrates were concentrated, the residue was treated with diethyl ether and concentrated to afford crude S-36 as a white foam. No further purification. Yield: 74 \%. [ES-MS] (ESI+): $\mathrm{m} / \mathrm{z}$ calcd for $\mathrm{C}_{24} \mathrm{H}_{24} \mathrm{~F}_{2} \mathrm{~N}_{5} \mathrm{O}_{2}[\mathrm{M}+\mathrm{H}]^{+}$, 452.2; found, 452.1 .

\section{N-(3-(5-((1-Acryloylazetidin-3-yl)oxy)-6-aminopyrimidin-4-yl)-5-fluoro-2-methylphenyl)-4- cyclopropyl-2-fluorobenzamide (14)}

To a solution of acrylic acid (51.0 mg, $0.708 \mathrm{mmol})$ in DMF $(1.00 \mathrm{~mL})$ was added DIPEA (0.247 mL, $1.415 \mathrm{mmol})$ followed by T3P (50 \% in DMF) (0.358 mL, $0.613 \mathrm{mmol})$. The mixture was stirred at RT for $30 \mathrm{~min}$ and was then added dropwise to a solution of S-36 (213 mg, 0.472 mmol) in DMF (3.50 mL) at $0{ }^{\circ} \mathrm{C}$. The reaction mixture was stirred at $0{ }^{\circ} \mathrm{C}$ for $100 \mathrm{~min}$. It was then diluted with EtOAc and washed with saturated aqueous $\mathrm{NaHCO}_{3}$ solution. The aqueous layer was back-extracted with EtOAc. The combined organic layers were washed with brine (2x), dried over $\mathrm{MgSO}_{4}$, filtered and concentrated. The residue was purified by column chromatography ( $\mathrm{SiO}_{2} ; \mathrm{CH}_{2} \mathrm{Cl}_{2} /\left(\mathrm{MeOH}\right.$ with $\left.2 \% \mathrm{NH}_{3}\right)$ gradient) to afford 14 as a white solid. Yield: $64 \%$. [ESMS] (ESI+): m/z calcd for $\mathrm{C}_{27} \mathrm{H}_{26} \mathrm{~F}_{2} \mathrm{~N}_{5} \mathrm{O}_{3}[\mathrm{M}+\mathrm{H}]^{+}$, 506.2; found, 506.2. ${ }^{1} \mathrm{H}$ NMR (400 MHz, DMSO-d $\left.\mathrm{d}_{6}\right) \delta 9.88(\mathrm{~s}, 1 \mathrm{H}), 8.20(\mathrm{~s}, 1 \mathrm{H}), 7.70-7.61(\mathrm{~m}, 1 \mathrm{H}), 7.61-7.48(\mathrm{~m}, 1 \mathrm{H}), 7.21-6.98(\mathrm{~m}$, 5H), 6.14 (dd, 1H), 6.01 (dd, 1H), 5.61 (dd, 1H), 4.38 - 4.29 (m, 1H), 4.11 - 3.93 (m, 2H), 3.81 $3.66(\mathrm{~m}, 2 \mathrm{H}), 2.10-1.96(\mathrm{~m}, 1 \mathrm{H})$ overlapping with $2.94(\mathrm{~s}, 3 \mathrm{H}), 1.12-0.98(\mathrm{~m}, 2 \mathrm{H}), 0.86-0.73$ (m, 2H). ${ }^{13} \mathrm{C}$ NMR (101 MHz, DMSO-d 6 ) $\delta 164.40,162.66,160.81,160.49,158.54,158.34$, 158.08, 153.15, 152.85, 152.83, 150.74, 150.65, 138.54, 138.45, 138.00, 137.89, 135.29, 130.28, 130.25, 126.88, 126.62, 126.49, 121.55, 121.52, 120.44, 120.30, 113.17, 112.96, 112.71, 112.48, 112.28, 71.08, 57.27, 55.14, 15.10, 15.08, 14.23, 10.48. HRMS (ESI+): $\mathrm{m} / \mathrm{z}$ calcd for $\mathrm{C}_{27} \mathrm{H}_{26} \mathrm{~F}_{2} \mathrm{~N}_{5} \mathrm{O}_{3}[\mathrm{M}+\mathrm{H}]+$, 506.19982; found, 506.20004. 
tert-Butyl 3-((4-amino-6-(5-fluoro-3-(2-fluoro-4-(2-hydroxypropan-2-yl)benzamido)-2methylphenyl)pyrimidin-5-yl)oxy)azetidine-1-carboxylate (S-37)

To a solution of S-32 (300 mg, $0.948 \mathrm{mmol})$ in DME (4.0 mL) and water (0.57 mL) was added S10 (490 mg, $1.137 \mathrm{mmol}$ ) followed by aqueous $\mathrm{Na}_{2} \mathrm{CO}_{3}$ solution (1 M, $2.84 \mathrm{~mL}, 2.84 \mathrm{mmol}$ ). After purging with argon for $10 \mathrm{~min}, \mathrm{PdCl}_{2}\left(\mathrm{PPh}_{3}\right)_{2}$ (33.3 mg, $0.047 \mathrm{mmol}$ ) was added and the reaction mixture was stirred at $85{ }^{\circ} \mathrm{C}$ for $6 \mathrm{~h}$. It was then diluted with saturated aqueous $\mathrm{NaHCO}_{3}$ solution and EtOAc. A white solid formed, which was filtered off, washed with DCM, and dried to afford S-37. Yield: 72 \%. [ES-MS] (ESI+): m/z calcd for $\mathrm{C}_{29} \mathrm{H}_{34} \mathrm{~F}_{2} \mathrm{~N}_{5} \mathrm{O}_{5}[\mathrm{M}+\mathrm{H}]^{+}$, 570.3; found, 570.2. ${ }^{1} \mathrm{H}$ NMR (400 MHz, DMSO-d $) \delta 9.94(\mathrm{~s}, 1 \mathrm{H}), 8.19$ (s, 1H), 7.75 - 7.66 (m, 1H), 7.63 - 7.54 (m, 1H), $7.46-7.35$ (m, 2H), 7.08 (s, 2H), $7.04-6.99$ (m, 1H), 5.29 (s, 1H), $4.28-4.20$ (m, 1H), 3.63 (s, br, 4H), 2.04 (s, 3H), 1.45 (s, 6H), 1.31 (s, 9H).

\section{N-(3-(5-((1-Acryloylazetidin-3-yl)oxy)-6-aminopyrimidin-4-yl)-5-fluoro-2-methylphenyl)-2- fluoro-4-(2-hydroxypropan-2-yl)benzamide (15)}

To a solution of S-37 $(190 \mathrm{mg}, 0.300 \mathrm{mmol})$ in $\mathrm{DCM}(4.0 \mathrm{~mL})$ at $0^{\circ} \mathrm{C}$ was added TFA $(0.231 \mathrm{~mL}$, $3.00 \mathrm{mmol})$. The reaction mixture was stirred at RT for $6 \mathrm{~h}$, then loaded on a $\mathrm{PL}_{-\mathrm{HCO}} \mathrm{MP} \mathrm{SPE}^{-}$ cartridge (5 g) and eluted with $\mathrm{MeOH}$. The product containing fractions were combined and concentrated to afford crude S-38 as free base. Yield: 76 \%. [ES-MS] (ESI+): m/z calcd for $\mathrm{C}_{24} \mathrm{H}_{26} \mathrm{~F}_{2} \mathrm{~N}_{5} \mathrm{O}_{3}[\mathrm{M}+\mathrm{H}]+$, 470.2; found, 470.2 .

A stock solution of acryloyl chloride $(0.130 \mathrm{~mL}, 145 \mathrm{mg}, 1.600 \mathrm{mmol})$ in DCM $(1.0 \mathrm{~mL})$ was prepared. To a solution of crude S-38 $(187 \mathrm{mg}, 0.378 \mathrm{mmol})$ and triethylamine $(0.158 \mathrm{~mL}, 1.135$ mmol) in DCM (5.0 mL) at $-10{ }^{\circ} \mathrm{C}$ was added acryloyl chloride stock solution $(0.100 \mathrm{~mL})$. The reaction mixture was stirred at RT for $60 \mathrm{~min}$, and two more portions of stock solution $(0.100 \mathrm{~mL}$ 
each) were added at $-10{ }^{\circ} \mathrm{C}$ after 30 and 45 min, respectively. The mixture was then diluted with saturated aqueous $\mathrm{NH}_{4} \mathrm{Cl}$ solution and extracted with EtOAc. The organic layer was washed with brine, dried over $\mathrm{MgSO}_{4}$, filtered and concentrated. The residue was purified by column chromatography ( $\mathrm{SiO}_{2}$; (DCM with $2 \%$ ammonia)/MeOH gradient) to afford $\mathbf{1 5}$ as a white solid. Yield: 58 \%. [ES-MS] (ESI+): m/z calcd for $\mathrm{C}_{27} \mathrm{H}_{28} \mathrm{~F}_{2} \mathrm{~N}_{5} \mathrm{O}_{4}[\mathrm{M}+\mathrm{H}]^{+}$, 524.2; found, 524.1. ${ }^{1} \mathrm{H}$ NMR (400 MHz, DMSO-d 6 ) $\delta 9.96$ (s, 1H), 8.20 (s, 1H), 7.76 - 7.67 (m, 1H), 7.59 - 7.50 (m, 1H), 7.45 - 7.37 (m, 2H), 7.12 (s, br, 2H), 7.05 (dd, 1H), 6.14 (dd, 1H), 6.01 (dd, 1H), 5.61 (dd, 1H), $5.29(\mathrm{~s}, 1 \mathrm{H}), 4.37-4.28(\mathrm{~m}, 1 \mathrm{H}), 4.12-4.01(\mathrm{~m}, 1 \mathrm{H}), 4.01-3.94(\mathrm{~m}, 1 \mathrm{H}), 3.78-3.67$ (m, $2 \mathrm{H})$, 2.05 (s, 3H), 1.45 (s, 6H). ${ }^{13} \mathrm{C}$ NMR (101 MHz, DMSO-d 6 ) $\delta$ 164.39, 162.81, 160.48, 160.28, 158.53, 158.08, 157.82, 156.75, 156.69, 153.15, 152.82, 138.55, 138.46, 137.94, 137.83, 135.29, 129.86, 126.86, 126.67, 126.48, 121.41, 121.27, 120.73, 113.21, 113.00, 112.51, 112.44, 112.27, 112.20, 71.09, 70.59, 57.27, 55.14, 31.54, 14.24. HRMS (ESI+): m/z calcd for $\mathrm{C}_{27} \mathrm{H}_{28} \mathrm{~F}_{2} \mathrm{~N}_{5} \mathrm{O}_{4}[\mathrm{M}$ $+\mathrm{H}]+$, 524.21039; found, 524.21057.

tert-Butyl 3-((4-amino-6-(3-(2,3-difluoro-4-(2-hydroxypropan-2-yl)benzamido)-5-fluoro-2methylphenyl)pyrimidin-5-yl)oxy)azetidine-1-carboxylate (S-39)

To a solution of S-32 (380 mg, $1.200 \mathrm{mmol})$ in DME (5.0 mL) and water $(0.71 \mathrm{~mL})$ was added S15 (593 mg, $1.320 \mathrm{mmol}$ ) followed by aqueous $\mathrm{Na}_{2} \mathrm{CO}_{3}$ solution (1 M, $\left.3.60 \mathrm{~mL}, 3.60 \mathrm{mmol}\right)$. After purging with argon for $10 \mathrm{~min}, \mathrm{PdCl}_{2}\left(\mathrm{PPh}_{3}\right)_{2}(42.1 \mathrm{mg}, 0.060 \mathrm{mmol})$ was added and the reaction mixture was stirred at $85^{\circ} \mathrm{C}$ for $6 \mathrm{~h}$. It was then diluted with saturated aqueous $\mathrm{NaHCO}_{3}$ solution and EtOAc. A white solid formed, which was filtered off and dried in vacuo to afford S-39. Yield: 67 \%. [ES-MS] (ESI+): m/z calcd for $\mathrm{C}_{29} \mathrm{H}_{33} \mathrm{~F}_{3} \mathrm{~N}_{5} \mathrm{O}_{5}[\mathrm{M}+\mathrm{H}]^{+}$, 588.2; found, 588.2. ${ }^{1} \mathrm{H}$ NMR (400 
MHz, Methanol-d 4 ) $\delta 8.21(\mathrm{~s}, 1 \mathrm{H}), 7.65-7.54$ (m, 3H), 7.08 (dd, 1H), $4.42-4.34$ (m, 1H), 3.83

- 3.69 (m, 4H), 2.16 (s, 3H), 1.62 (s, 6H), 1.38 (s, 9H), 4 exchangeable protons not observed.

\section{N-(3-(5-((1-Acryloylazetidin-3-yl)oxy)-6-aminopyrimidin-4-yl)-5-fluoro-2-methylphenyl)- 2,3-difluoro-4-(2-hydroxypropan-2-yl)benzamide (16)}

To a suspension of S-39 (500 mg, $0.808 \mathrm{mmol})$ in DCM $(10.0 \mathrm{~mL})$ at $0{ }^{\circ} \mathrm{C}$ was added TFA $(0.623$ $\mathrm{mL}, 8.08 \mathrm{mmol}$ ). The reaction mixture was stirred at RT for $14 \mathrm{~h}$, then loaded on a PL-HCO 3 MP SPE cartridge (5 g) and eluted with $\mathrm{MeOH}$. The product containing fractions were combined and concentrated to afford crude $\mathbf{S}-\mathbf{4 0}$ as free base. Yield: $80 \%$. [ES-MS] (ESI+): m/z calcd for $\mathrm{C}_{24} \mathrm{H}_{25} \mathrm{~F}_{3} \mathrm{~N}_{5} \mathrm{O}_{3}[\mathrm{M}+\mathrm{H}]^{+}$, 488.2; found, 488.1.

A stock solution of acryloyl chloride $(0.130 \mathrm{~mL}, 145 \mathrm{mg}, 1.600 \mathrm{mmol})$ in DCM $(1.0 \mathrm{~mL})$ was prepared. To a solution of crude S-40 (200 mg, $0.369 \mathrm{mmol})$ and triethylamine $(0.154 \mathrm{~mL}, 1.108$ mmol) in DCM (5.0 mL) at $-10^{\circ} \mathrm{C}$ was added acryloyl chloride stock solution $(0.100 \mathrm{~mL})$. The reaction mixture was stirred at $\mathrm{RT}$ for $90 \mathrm{~min}$, and two more portions of stock solution $(0.100 \mathrm{~mL}$ each) were added at $-10{ }^{\circ} \mathrm{C}$ after $30 \mathrm{~min}$ and $60 \mathrm{~min}$. The mixture was then diluted with saturated aqueous $\mathrm{NH}_{4} \mathrm{Cl}$ solution and extracted with EtOAc. The organic layer was washed with brine, dried over $\mathrm{MgSO}_{4}$, filtered and concentrated. The residue was purified by column chromatography ( $\mathrm{SiO}_{2}$; (DCM with $2 \%$ ammonia)/MeOH gradient) to afford $\mathbf{1 6}$ as a white solid. Yield: $36 \%$. [ESMS] (ESI+): m/z calcd for $\mathrm{C}_{27} \mathrm{H}_{27} \mathrm{~F}_{3} \mathrm{~N}_{5} \mathrm{O}_{4}[\mathrm{M}+\mathrm{H}]^{+}$, 542.2; found, 542.2. ${ }^{1} \mathrm{H}$ NMR (400 MHz, DMSO-d $\left.{ }_{6}\right) \delta 10.13(\mathrm{~s}, 1 \mathrm{H}), 8.20(\mathrm{~s}, 1 \mathrm{H}), 7.59-7.48$ (m, 3H), 7.13 (s, br, 2H), 7.07 (dd, 1H), 6.14 (dd, 1H), 6.01 (dd, 1H), 5.61 (dd, 1H), 5.57 (s, 1H), $4.37-4.29$ (m, 1H), $4.12-4.01$ (m, 1H), 4.01 - 3.94 (m, 1H), $3.79-3.66$ (m, 2H), 2.05 (s, 3H), 1.52 (s, 6H). ${ }^{13} \mathrm{C}$ NMR (101 MHz, DMSO-d 6 ) $\delta$ 164.40, 161.79, 160.48, 158.54, 158.08, 153.17, 152.77, 148.89, 148.74, 148.06, 147.92, 146.40, 
146.25, 145.60, 145.47, 141.65, 141.54, 138.65, 138.56, 137.62, 137.51, 135.28, 126.85, 126.49,

124.17, 124.05, 123.87, 121.77, 113.51, 113.29, 112.67, 112.44, 71.10, 69.71, 57.27, 55.13, 29.81, 14.26. HRMS (ESI+): m/z calcd for $\mathrm{C}_{27} \mathrm{H}_{27} \mathrm{~F}_{3} \mathrm{~N}_{5} \mathrm{O}_{4}[\mathrm{M}+\mathrm{H}]+$, 542.20097; found, 542.20117.

\section{6-Amino-4-chloro-5-iodopyrimidine (S-41)}

To a solution of 4,6-dichloro-5-iodopyrimidine (2.00 g, $7.28 \mathrm{mmol})$ in 2-propanol $(6.0 \mathrm{~mL})$ in an autoclave was added aqueous ammonium hydroxide solution (26 \%, $1.31 \mathrm{~mL}, 8.73 \mathrm{mmol})$. The reaction mixture was heated at $70{ }^{\circ} \mathrm{C}$ for $15 \mathrm{~h}$. It was poured onto water and extracted with EtOAc. The organic layer was washed with brine, dried over $\mathrm{MgSO}_{4}$, filtered and concentrated. The residue was dried in vacuo to afford S-41 as a pale yellow solid. Yield: $80 \%$. [ES-MS] (ESI+): $\mathrm{m} / \mathrm{z}$ calcd for $\mathrm{C}_{4} \mathrm{H}_{4} \mathrm{ClIN}_{3}[\mathrm{M}+\mathrm{H}]^{+}$, 255.9; found, 255.9. ${ }^{1} \mathrm{H}$ NMR (400 MHz, DMSO-d 6 ) $\delta 8.12$ (s, 1H), 7.86 (s, br, 1H), 6.95 (s, br, 1H).

\section{tert-Butyl (E)-(3-(4-amino-6-chloropyrimidin-5-yl)allyl)(methyl)carbamate (S-42)}

To a solution of S-19 (1.41 g, $4.28 \mathrm{mmol})$ and S-41 (1.05 g, $3.89 \mathrm{mmol})$ in DME (21.0 mL) and water $(3.0 \mathrm{~mL})$ was added aqueous $\mathrm{Na}_{2} \mathrm{CO}_{3}$ solution $(1 \mathrm{M}, 11.67 \mathrm{~mL}, 11.67 \mathrm{mmol})$. After purging with argon for $10 \mathrm{~min}, \mathrm{PdCl}_{2}\left(\mathrm{PPh}_{3}\right)_{2}(0.137 \mathrm{~g}, 0.195 \mathrm{mmol})$ was added and the reaction mixture was stirred at $85{ }^{\circ} \mathrm{C}$ for $15 \mathrm{~h}$. It was then diluted with saturated aqueous $\mathrm{NaHCO}_{3}$ solution and extracted with EtOAc. The organic layer was washed with water and brine, dried over $\mathrm{MgSO}_{4}$, filtered and concentrated. The residue was purified by column chromatography $\left(\mathrm{SiO}_{2}\right.$; DCM/MeOH gradient) to afford S-42 as a yellow solid. Yield: 64 \%. [ES-MS] (ESI+): m/z calcd for $\mathrm{C}_{13} \mathrm{H}_{20} \mathrm{ClN}_{4} \mathrm{O}_{2}[\mathrm{M}+\mathrm{H}]^{+}$, 299.1; found, 299.1. ${ }^{1} \mathrm{H}$ NMR (400 MHz, Methanol-d 4 ) $\delta 8.08(\mathrm{~s}$, 
1H), $6.26(\mathrm{~d}, 1 \mathrm{H}), 6.20-6.03(\mathrm{~m}, 1 \mathrm{H}), 4.03$ (d, 2H), 2.94 (s, 3H), 1.48 (s, 9H), 2 exchangeable protons not observed.

tert-Butyl (E)-(3-(4-amino-6-(3-(4-cyclopropyl-2-fluorobenzamido)-5-fluoro-2-methylphenyl)pyrimidin-5-yl)allyl)(methyl)carbamate (S-43)

To a solution of S-42 (618 mg, $1.97 \mathrm{mmol})$ in DME $(14.0 \mathrm{~mL})$ and water $(2.0 \mathrm{~mL})$ was added 38 (893 mg, $2.162 \mathrm{mmol}$ ) followed by aqueous $\mathrm{Na}_{2} \mathrm{CO}_{3}$ solution (1 M, $5.90 \mathrm{~mL}, 5.90 \mathrm{mmol}$ ). After purging with argon for $10 \mathrm{~min}, \mathrm{PdCl}_{2}\left(\mathrm{PPh}_{3}\right)_{2}(69.0 \mathrm{mg}, 0.098 \mathrm{mmol})$ was added and the reaction mixture was stirrred at $80{ }^{\circ} \mathrm{C}$ for $5 \mathrm{~h}$. More 38 (350 mg, $\left.0.85 \mathrm{mmol}\right)$ and $\mathrm{PdCl}_{2}\left(\mathrm{PPh}_{3}\right)_{2}(40 \mathrm{mg}$, $0.057 \mathrm{mmol}$ ) were added and the reaction mixture was stirred at $80^{\circ} \mathrm{C}$ for an additional $10 \mathrm{~h}$. It was then diluted with aqueous saturated $\mathrm{NaHCO}_{3}$ solution and extracted with EtOAc. The organic layer was washed with water and brine, dried over $\mathrm{MgSO}_{4}$, filtered and concentrated. The residue was purified by column chromatography ( $\mathrm{SiO}_{2}$; DCM/EtOAc gradient) to afford $\mathbf{S}-\mathbf{4 3}$ as a beige solid. Yield: 55 \%. [ES-MS] (ESI+): m/z calcd for $\mathrm{C}_{30} \mathrm{H}_{34} \mathrm{~F}_{2} \mathrm{~N}_{5} \mathrm{O}_{3}[\mathrm{M}+\mathrm{H}]^{+}$, 550.3; found, 550.2. ${ }^{1} \mathrm{H}$ NMR (400 MHz, Methanol-d4) $\delta 8.32$ (s, 1H), 7.83 - 7.74 (m, 1H), 7.70 (d, 1H), 7.06 (d, 1H), 6.97 (d, 1H), $6.91-6.83(\mathrm{~m}, 1 \mathrm{H}), 6.17-5.96(\mathrm{~m}, 1 \mathrm{H}), 5.73-5.62(\mathrm{~m}, 1 \mathrm{H}), 3.80(\mathrm{~d}, 2 \mathrm{H}), 2.59$ (s, 3H), $2.08-1.97$ (m, 1H) overlapping with 2.05 (s, 3H), 1.39 (s, 9H), 1.16 - 1.06 (m, 2H), 0.85 0.77 (m, 2H), 3 exchangeable protons not observed.

(E)-N-(3-(6-Amino-5-(3-(N-methylacrylamido)prop-1-en-1-yl)pyrimidin-4-yl)-5-fluoro-2methylphenyl)-4-cyclopropyl-2-fluorobenzamide (17)

To a solution of S-43 $(763 \mathrm{mg}, 1.388 \mathrm{mmol}$ in DCM $(15 \mathrm{~mL})$ was added TFA $(1.07 \mathrm{~mL}, 13.88$ mmol). The reaction mixture was stirred at RT for $12 \mathrm{~h}$, then it was added to a suspension of 
PL-HCO 3 MP (8.0 g, $2.18 \mathrm{mmol} / \mathrm{g})$ in DCM (40 mL). The mixture was stirred vigorously for 30 min, filtered through a pad of Celite and washed with DCM. The filtrate was concentrated under reduced pressure. The residue was loaded on a $\mathrm{PL}-\mathrm{HCO}_{3} \mathrm{MP}$ SPE cartridge, washed with DCM (2 mL) and $\mathrm{MeOH}(5 \mathrm{~mL})$. The $\mathrm{MeOH}$ fraction was concentrated to afford a first batch of S-44. The polymer on the Celite was washed with more $\mathrm{MeOH}$, the filtrate was concentrated to afford a second batch of S-44. The two batches were combined to afford crude S-44. [ES-MS] (ESI+): m/z calcd for $\mathrm{C}_{25} \mathrm{H}_{26} \mathrm{~F}_{2} \mathrm{~N}_{5} \mathrm{O}[\mathrm{M}+\mathrm{H}]^{+}$, 450.2; found, 450.2.

A stock solution of acryloyl chloride $(115 \mathrm{mg}, 0.130 \mathrm{~mL}, 1.60 \mathrm{mmol})$ in DCM $(1.0 \mathrm{~mL})$ was prepared. Acryloyl stock solution $(0.100 \mathrm{~mL})$ was added to a solution of crude S-44 (207 mg, $0.414 \mathrm{mmol})$ and triethylamine $(0.173 \mathrm{~mL}, 1.243 \mathrm{mmol})$ in DCM $(5.0 \mathrm{~mL})$ at $-10^{\circ} \mathrm{C}$. After stirring at RT for $30 \mathrm{~min}$, another portion of stock solution $(0.100 \mathrm{~mL})$ was added at $-10{ }^{\circ} \mathrm{C}$ and stirring was continued for another $30 \mathrm{~min}$ at RT. The mixture was quenched with saturated aqueous $\mathrm{NH}_{4} \mathrm{Cl}$ solution and extracted with EtOAc. The organic layer was washed with brine, dried over $\mathrm{MgSO}_{4}$, filtered and concentrated. The residue was purified by column chromatography $\left(\mathrm{SiO}_{2} ; \mathrm{EtOAc}\right)$ followed by a second column chromatography ( $\mathrm{SiO}_{2}$; (DCM with $2 \%$ ammonia)/MeOH gradient) to afford $\mathbf{1 7}$ as a beige solid after trituration with pentane and diethylether. Yield: 33 \%. [ES-MS] (ESI+): $\mathrm{m} / \mathrm{z}$ calcd for $\mathrm{C}_{28} \mathrm{H}_{28} \mathrm{~F}_{2} \mathrm{~N}_{5} \mathrm{O}_{2}[\mathrm{M}+\mathrm{H}]^{+}$, 504.2; found, 504.2. ${ }^{1} \mathrm{H}$ NMR (400 MHz, DMSO$\left.\mathrm{d}_{6}\right)$ rotamers $\delta 9.72$ and $9.68(2 \mathrm{~s}$, total $1 \mathrm{H}), 8.31(\mathrm{~s}, 1 \mathrm{H}), 7.70-7.60(\mathrm{~m}, 1 \mathrm{H}), 7.56-7.45(\mathrm{~m}, 1 \mathrm{H})$, $7.12-7.02$ (m, 2H), $7.02-6.79$ (m, 3H), 6.59 and 6.48 (2dd, total 1H), $6.14-5.89$ (m, 2H), 5.65 - 5.50 and $5.49-5.37$ (2m, total 2H), 3.94 and 3.90 (2d, total $2 \mathrm{H}), 2.69$ and 2.67 (2s, total 3H), $2.08-1.98(\mathrm{~m}, 1 \mathrm{H}), 1.96-1.86(\mathrm{~m}, 3 \mathrm{H}), 1.10-1.00(\mathrm{~m}, 2 \mathrm{H}), 0.84-0.73(\mathrm{~m}, 2 \mathrm{H}) .{ }^{13} \mathrm{C}$ NMR (151 MHz, DMSO-d 6 ) rotamers $\delta 165.32,164.93,162.53,161.35,161.34,161.28,161.27,161.13$, 161.12, 160.41, 160.12, 160.07, 158.76, 158.53, 158.47, 156.05, 155.99, 150.73, 150.71, 150.68, 
150.65, 141.40, 141.34, 141.22, 141.16, 137.85, 137.78, 137.73, 137.66, 131.97, 131.42, 130.28, 128.39, 128.22, 126.99, 126.92, 125.00, 124.77, 123.84, 122.26, 121.54, 120.44, 120.41, 120.35, 120.32, 112.65, 112.49, 112.33, 112.23, 111.96, 111.29, 111.13, 111.11, 110.94, 50.98, 48.88, 34.02, 33.17, 15.09, 15.08, 13.94, 13.90, 10.47. HRMS (ESI+): $\mathrm{m} / \mathrm{z}$ calcd for $\mathrm{C}_{28} \mathrm{H}_{28} \mathrm{~F}_{2} \mathrm{~N}_{5} \mathrm{O}_{2}[\mathrm{M}+$ H] $]^{+}$, 504.22056; found, 504.22067.

\section{tert-Butyl (2-((4-amino-6-chloropyrimidin-5-yl)oxy)ethyl)carbamate (S-45)}

To a solution of 41 (1.00 g, $6.18 \mathrm{mmol})$ and tert-butyl (2-hydroxyethyl)carbamate (1.99 g, 12.37 mmol) in THF (50 mL) was added SMOPEX-301 (1 mmol/g) (15.46 g, $15.46 \mathrm{mmol})$ followed by the dropwise addition of DIAD (3.01 mL, $15.46 \mathrm{mmol})$. The reaction mixture was stirred at $60{ }^{\circ} \mathrm{C}$ for $2 \mathrm{~h}$. It was then filtered through a pad of Celite and concentrated. The residue was purified by column chromatography ( $\mathrm{SiO}_{2}$; DCM/EtOAc gradient) to afford $\mathbf{S}-\mathbf{4 5}$ as a white solid. Yield: 54 \%. [ES-MS] (ESI+): m/z calcd for $\mathrm{C}_{11} \mathrm{H}_{18} \mathrm{ClN}_{4} \mathrm{O}_{3}[\mathrm{M}+\mathrm{H}]^{+}$, 289.1; found, 289.1. ${ }^{1} \mathrm{H}$ NMR (400 MHz, Methanol- $\left.\mathrm{d}_{4}\right) \delta 7.95(\mathrm{~s}, 1 \mathrm{H}), 4.02(\mathrm{t}, 2 \mathrm{H}), 3.42(\mathrm{t}, 2 \mathrm{H}), 1.45(\mathrm{~s}, 9 \mathrm{H}), 3$ exchangeable protons not observed.

tert-Butyl (2-((4-amino-6-(3-(4-cyclopropyl-2-fluorobenzamido)-5-fluoro-2-methylphenyl)pyrimidin-5-yl)oxy)ethyl)carbamate (S-46)

To a solution of S-45 (500 mg, $1.732 \mathrm{mmol})$ in DME $(7.0 \mathrm{~mL})$ and water $(1.0 \mathrm{~mL})$ was added 38 (787 mg, $1.905 \mathrm{mmol}$ ) followed by aqueous $\mathrm{Na}_{2} \mathrm{CO}_{3}$ solution (1 M, $5.2 \mathrm{~mL}, 5.20 \mathrm{mmol}$ ). After purging with argon for $10 \mathrm{~min}, \mathrm{PdCl}_{2}\left(\mathrm{PPh}_{3}\right)_{2}(60.8 \mathrm{mg}, 0.087 \mathrm{mmol})$ was added and the reaction mixture was heated at $110{ }^{\circ} \mathrm{C}$ for $15 \mathrm{~min}$ under microwave irradiation. More 38 (286 mg, 0.692 mmol) and $\mathrm{PdCl}_{2}\left(\mathrm{PPh}_{3}\right)_{2}(20 \mathrm{mg}, 0.017 \mathrm{mmol})$ were added and the heating cycle was repeated. 
The mixture was diluted with saturated aqueous $\mathrm{NaHCO}_{3}$ solution and extracted with EtOAc. The organic layer was washed with brine, dried over $\mathrm{MgSO}_{4}$, filtered and concentrated. The residue was purified by column chromatography $\left(\mathrm{SiO}_{2}\right.$; DCM/EtOAc gradient) to afford $\mathbf{S - 4 6}$ as a grey solid. Yield: 77 \%. [ES-MS] (ESI+): m/z calcd for $\mathrm{C}_{28} \mathrm{H}_{32} \mathrm{~F}_{2} \mathrm{~N}_{5} \mathrm{O}_{4}$ [M + H] ${ }^{+}$, 540.2; found, 540.3.

${ }^{1} \mathrm{H}$ NMR (400 MHz, DMSO-d 6 ) $\delta 9.81(\mathrm{~s}, 1 \mathrm{H}), 8.17(\mathrm{~s}, 1 \mathrm{H}), 7.65(\mathrm{t}, 1 \mathrm{H}), 7.60-7.49(\mathrm{~m}, 1 \mathrm{H})$, $7.12-6.94$ (m, br, 5H), $6.87-6.78(\mathrm{~m}, 1 \mathrm{H}), 3.37$ (t, 2H), $3.04-2.95$ (m, 2H), 2.07 - 1.97 (m, 1H) overlapping with 2.04 (s, 3H), 1.33 (s, 9H), $1.09-1.00$ (m, 2H), $0.82-0.75$ (m, 2H).

\section{N-(3-(5-(2-Acrylamidoethoxy)-6-aminopyrimidin-4-yl)-5-fluoro-2-methylphenyl)-4- cyclopropyl-2-fluorobenzamide (18)}

To a solution of S-46 (130 mg, $0.241 \mathrm{mmol})$ in DCM $(4.0 \mathrm{~mL})$ was added TFA (0.186 mL, 2.409 mmol). The reaction mixture was stirred at RT for $15 \mathrm{~h}$, then concentrated to afford crude S-47 as TFA salt. [ES-MS] (ESI+): m/z calcd for $\mathrm{C}_{23} \mathrm{H}_{24} \mathrm{~F}_{2} \mathrm{~N}_{5} \mathrm{O}_{2}$ [M + H]+, 440.2; found, 440.2.

To a solution of acrylic acid (0.023 mL, $0.330 \mathrm{mmol})$ in DMF (2.0 mL) was added DIPEA (0.115 $\mathrm{mL}, 0.660 \mathrm{mmol}$ ) followed by T3P (50 \% in DMF, $0.167 \mathrm{~mL}, 0.286 \mathrm{mmol})$. The mixture was stirred at RT for 30 min to form the active ester. This solution was added dropwise to a solution of crude S-47 (191 mg, $0.220 \mathrm{mmol})$ and DIPEA (0.115 mL, $0.660 \mathrm{mmol})$ in DMF (2.0 mL) at 0 ${ }^{\circ} \mathrm{C}$. The reaction mixture was stirred at $0{ }^{\circ} \mathrm{C}$ for $30 \mathrm{~min}$ and was then diluted with water and extracted with EtOAc. The organic layer was washed with water (2x) and brine (2x), dried over $\mathrm{MgSO}_{4}$, filtered and concentrated. The residue was purified by column chromatography $\left(\mathrm{SiO}_{2}\right.$; (DCM with $2 \%$ ammonia)/MeOH gradient) to afford $\mathbf{1 8}$ as a white solid after trituration with diethyl ether. Yield: $60 \%$ over 2 steps. [ES-MS] (ESI+): m/z calcd for $\mathrm{C}_{26} \mathrm{H}_{26} \mathrm{~F}_{2} \mathrm{~N}_{5} \mathrm{O}_{3}[\mathrm{M}+\mathrm{H}]^{+}$, 494.2; found, 494.2. ${ }^{1} \mathrm{H}$ NMR (400 MHz, DMSO-d $)$ ) $9.82(\mathrm{~s}, 1 \mathrm{H}), 8.18(\mathrm{~s}, 1 \mathrm{H}), 8.07(\mathrm{t}, 1 \mathrm{H}), 7.71$ 
- 7.62 (m, 1H), $7.59-7.47$ (m, 1H), 7.15 - 6.96 (m, br, 5H), 6.14 (dd, 1H), 6.03 (dd, 1H), 5.55

(dd, 1H), $3.43(\mathrm{t}, 2 \mathrm{H}), 3.25-3.18(\mathrm{~m}, 2 \mathrm{H}), 2.09-1.98(\mathrm{~m}, 1 \mathrm{H})$ overlapping with $2.04(\mathrm{~s}, 3 \mathrm{H})$, $1.09-1.01$ (m, 2H), $0.83-0.76$ (m, 2H). ${ }^{13} \mathrm{C}$ NMR (101 MHz, DMSO-d 6 ) $\delta$ 164.74, 162.58, 160.84, 160.38, 158.59, 158.37, 157.98, 152.76, 150.81, 150.73, 138.64, 138.56, 137.71, 137.61, 136.07, 131.37, 130.27, 126.32, 125.23, 121.54, 120.31, 120.17, 112.96, 112.71, 112.48, 112.06, 111.82, 71.72, 15.08, 14.34, 10.48, one signal overlapping with DMSO. HRMS (ESI+): m/z calcd for $\mathrm{C}_{26} \mathrm{H}_{26} \mathrm{~F}_{2} \mathrm{~N}_{5} \mathrm{O}_{3}[\mathrm{M}+\mathrm{H}]+$, 494.19982; found, 494.20013.

\section{tert-Butyl (2-((4-amino-6-chloropyrimidin-5-yl)amino)ethyl)carbamate (S-49)}

To a suspension of 6-chloropyrimidine-4,5-diamine (300 mg, $1.971 \mathrm{mmol}$ ) in MeOH (6.0 mL) was added tert-butyl (2-oxoethyl)carbamate (165 mg, $0.986 \mathrm{mmol})$. The mixture was stirred at RT for $1 \mathrm{~h}$, then decaborane (24 mg, $0.197 \mathrm{mmol}$ ) was added. Stirring was continued for $45 \mathrm{~h}$, after $15 \mathrm{~h}$ a second portion of (2-oxoethyl)carbamate (125 mg, $0.788 \mathrm{mmol})$ and decaborane (24 mg, 0.197 mmol), and after $30 \mathrm{~h}$ a third portion of (2-oxoethyl)carbamate (63 mg, $0.394 \mathrm{mmol}$ ) and decaborane (24.10 mg, $0.197 \mathrm{mmol}$ ) were added. The mixture was absorbed on Isolute and purified by column chromatography ( $\mathrm{SiO}_{2}$; DCM/EtOAc gradient) to afford $\mathbf{S - 4 9}$ as a yellow oil. Yield: 46 \%. [ES-MS] (ESI+): $\mathrm{m} / \mathrm{z}$ calcd for $\mathrm{C}_{11} \mathrm{H}_{19} \mathrm{ClN}_{5} \mathrm{O}_{2}[\mathrm{M}+\mathrm{H}]^{+}$, 288.1; found, 288.2. ${ }^{1} \mathrm{H}$ NMR (400 MHz, DMSO-d $\left.\mathrm{d}_{6}\right) \quad 7.87$ (s, 1H), $6.99-6.84(\mathrm{~m}, 3 \mathrm{H}), 4.08-3.99(\mathrm{~m}, 1 \mathrm{H}), 3.08-2.99(\mathrm{~m}, 2 \mathrm{H})$, $2.99-2.89$ (m, 2H), 1.37 (s, 9H). 
tert-Butyl (2-((4-amino-6-(3-(4-cyclopropyl-2-fluorobenzamido)-5-fluoro-2-methylphenyl)pyrimidin-5-yl)amino)ethyl)carbamate (S-50)

To a solution of S-49 (287 mg, $0.898 \mathrm{mmol})$ in DME $(7.0 \mathrm{~mL})$ and water $(1.0 \mathrm{~mL})$ was added 38 (445 mg, $1.077 \mathrm{mmol}$ ) followed by aqueous $\mathrm{Na}_{2} \mathrm{CO}_{3}$ solution (1 M, $2.69 \mathrm{~mL}, 2.69 \mathrm{mmol}$ ). After purging with argon for $10 \mathrm{~min}, \mathrm{PdCl}_{2}\left(\mathrm{PPh}_{3}\right)_{2}$ (31.5 mg, $0.045 \mathrm{mmol}$ ) was added and the reaction mixture was heated at $120{ }^{\circ} \mathrm{C}$ for 15 min under microwave irradiation. It was then diluted with saturated aqueous $\mathrm{NaHCO}_{3}$ solution and extracted with EtOAc. The organic layer was washed with water and brine, dried over $\mathrm{MgSO}_{4}$, filtered and concentrated. The residue was purified by column chromatography ( $\mathrm{SiO}_{2}$; DCM/EtOAc gradient) to afford S-50 as a grey solid. Yield: 43 \%. [ES-MS] (ESI+): m/z calcd for $\mathrm{C}_{28} \mathrm{H}_{33} \mathrm{~F}_{2} \mathrm{~N}_{6} \mathrm{O}_{3}[\mathrm{M}+\mathrm{H}]^{+}$, 539.3; found, 539.5. ${ }^{1} \mathrm{H}$ NMR (400 MHz, DMSO-d $\left.\mathrm{d}_{6}\right) \quad 9.72(\mathrm{~s}, 1 \mathrm{H}), 8.03(\mathrm{~s}, 1 \mathrm{H}), 7.70-7.61(\mathrm{~m}, 1 \mathrm{H}), 7.60-7.50(\mathrm{~m}, 1 \mathrm{H}), 7.11-7.02(\mathrm{~m}$, 2H), 6.93 (dd, 1H), 6.68 (s, 2H), 6.62 - 6.55 (m, 1H), 3.80 (t, 1H), 2.84 - 2.75 (m, 2H, overlapping with DMSO), $2.54-2.45$ (m, 2H), $2.07-1.95$ (m, 1H) overlapping with 2.00 (s, 3H), 1.32 (s, 9H), $1.09-0.99(\mathrm{~m}, 2 \mathrm{H}), 0.84-0.75(\mathrm{~m}, 2 \mathrm{H})$.

\section{N-(3-(5-((2-Acrylamidoethyl)amino)-6-aminopyrimidin-4-yl)-5-fluoro-2-methylphenyl)-4- cyclopropyl-2-fluorobenzamide (19)}

To a solution of S-50 (213 mg, $0.395 \mathrm{mmol})$ in DCM (4.0 mL) was added TFA (0.305 mL, 3.95 mmol). The reaction mixture was stirred at RT for $15 \mathrm{~h}$, then concentrated under reduced pressure to afford crude S-51 as TFA salt. No further purification. [ES-MS] (ESI+): m/z calcd for $\mathrm{C}_{23} \mathrm{H}_{25} \mathrm{~F}_{2} \mathrm{~N}_{6} \mathrm{O}[\mathrm{M}+\mathrm{H}]^{+}$, 439.2; found, 439.4.

To a solution of acrylic acid $(0.041 \mathrm{~mL}, 0.593 \mathrm{mmol})$ and DIPEA $(0.207 \mathrm{~mL}, 1.185 \mathrm{mmol})$ in DMF (2.0 mL) was added T3P (50\% in DMF, $0.300 \mathrm{~mL}, 0.514 \mathrm{mmol})$. The mixture was stirred at 
RT for 30 min to form the active ester. This solution was added dropwise to a solution of $\mathbf{S}-\mathbf{5 1}$ and DIPEA $(0.207 \mathrm{~mL}, 1.185 \mathrm{mmol})$ in DMF $(4.0 \mathrm{~mL})$ at $0{ }^{\circ} \mathrm{C}$. The reaction mixture was stirred at $0^{\circ}$ C for 2 h. It was then diluted with water and extracted with EtOAc. The organic layer was washed with water (2x) and brine (2x), dried over $\mathrm{MgSO}_{4}$, filtered and concentrated. The residue was purified by column chromatography ( $\mathrm{SiO}_{2}$; (DCM with $1 \%$ ammonia)/MeOH gradient) to afford

19 as a white solid. Yield: $63 \%$ over 2 steps. [ES-MS] (ESI+): m/z calcd for $\mathrm{C}_{26} \mathrm{H}_{27} \mathrm{~F}_{2} \mathrm{~N}_{6} \mathrm{O}_{2}[\mathrm{M}+$ $\mathrm{H}]^{+}$, 493.2; found, 493.2. ${ }^{1} \mathrm{H}$ NMR (400 MHz, DMSO-d 6 ) $\delta 9.74(\mathrm{~s}, 1 \mathrm{H}), 8.05(\mathrm{~s}, 1 \mathrm{H}), 7.90(\mathrm{t}, 1 \mathrm{H})$, $7.70-7.62(\mathrm{~m}, 1 \mathrm{H}), 7.59-7.47(\mathrm{~m}, 1 \mathrm{H}), 7.12$ - $7.01(\mathrm{~m}, 2 \mathrm{H}), 6.97-6.90(\mathrm{~m}, 1 \mathrm{H}), 6.69(\mathrm{~s}, 2 \mathrm{H})$, 6.10 (dd, 1H), 6.00 (dd, 1H), 5.52 (dd, 1H), 3.86 (t, 1H), 3.06 - 2.97 (m, 2H), 2.63 - 2.54 (m, 2H), $2.08-1.95$ (m, 1H) overlapping with 2.00 (s, 3H), $1.11-1.00(\mathrm{~m}, 2 \mathrm{H}), 0.83-0.74(\mathrm{~m}, 2 \mathrm{H}) .{ }^{13} \mathrm{C}$ NMR (101 MHz, DMSO-d 6 ) $\delta 165.26,163.05,161.34,160.99,158.88,158.79,158.60,151.31$, 151.29, 151.27, 151.18, 150.78, 141.26, 141.17, 138.22, 138.11, 132.01, 130.81, 130.77, 126.34, 126.31, 125.48, 125.24, 122.05, 122.03, 120.87, 120.73, 113.20, 113.15, 112.97, 111.80, 111.56, 46.30, 15.58, 14.56, 10.97. HRMS (ESI+): m/z calcd for $\mathrm{C}_{26} \mathrm{H}_{27} \mathrm{~F}_{2} \mathrm{~N}_{6} \mathrm{O}_{2}[\mathrm{M}+\mathrm{H}]+$, 493.21581; found, 493.21582.

\section{N-Boc-(S)-2-(hydroxymethyl)azetidine (S-53)}

The title compound S-53 was obtained following the procedure described for S-55 substituting (S)-1-(tert-butoxycarbonyl)azetidine-2-carboxylic acid for $(R)$-1-(tert-butoxycarbonyl)azetidine2-carboxylic acid. Yield: 86 \%. [ES-MS] (ESI+): m/z calcd for $\mathrm{C}_{9} \mathrm{H}_{18} \mathrm{NO}_{3}[\mathrm{M}+\mathrm{H}]^{+}, 188.1$; found, 188.1. 


\section{N-Boc-(R)-2-(hydroxymethyl)azetidine (S-55)}

To a solution of $(R)$-1-(tert-butoxycarbonyl)azetidine-2-carboxylic acid (2.00 g, $9.94 \mathrm{mmol})$ in THF (40 mL) at $0^{\circ} \mathrm{C}$ was added borane tetrahydrofuran complex solution (1 $\mathrm{M}$ in THF, $14.91 \mathrm{~mL}$, $14.91 \mathrm{mmol}$ ) dropwise. The reaction mixture was stirred at RT for $12 \mathrm{~h}$. It was then cooled to $0{ }^{\circ} \mathrm{C}$ and water (40 mL) was added carefully. The mixture was stirred at $0{ }^{\circ} \mathrm{C}$ for $20 \mathrm{~min}$, then it was diluted with water and extracted with EtOAc. The organic layer was washed with aqueous citric acid solution (10\%), saturated aqueous $\mathrm{NaHCO}_{3}$ solution and brine, dried over $\mathrm{MgSO}_{4}$, filtered and concentrated. The residue was dried in vacuo to afford S-55 as a pink oil. Yield: 90 \%. [ESMS] (ESI+): m/z calcd for $\mathrm{C}_{5} \mathrm{H}_{10} \mathrm{NO}_{3}[\mathrm{M}+\mathrm{H}-\mathrm{tBu}]^{+}$, 132.1; found, 132.1. ${ }^{1} \mathrm{H} \mathrm{NMR}(400 \mathrm{MHz}$, Methanol-d4) $\delta 4.33-4.22(\mathrm{~m}, 1 \mathrm{H}), 3.87-3.72(\mathrm{~m}, 3 \mathrm{H}), 3.69-3.58(\mathrm{~m}, 1 \mathrm{H}), 2.32$ - $2.10(\mathrm{~m}$, 2H), 1.44 (s, 9H), 1 exchangeable proton not observed.

N-(3-(5-((1-Acryloylpiperidin-4-yl)oxy)-6-aminopyrimidin-4-yl)-5-fluoro-2-methyl-phenyl)4-cyclopropyl-2-fluorobenzamide (20)

Step 1: tert-Butyl 4-((4-amino-6-chloropyrimidin-5-yl)oxy)piperidine-1-carboxylate (S-56a)

The title compound S-56a was obtained following the procedure described for S-29 substituting N-Boc-4-iodopiperidine for N-Boc-3-bromopyrrolidine. Yield: 55 \%. [ES-MS] (ESI+): m/z calcd for $\mathrm{C}_{14} \mathrm{H}_{22} \mathrm{ClN}_{4} \mathrm{O}_{3}[\mathrm{M}+\mathrm{H}]^{+}$, 329.1; found, 329.1.

Step $\quad 2$ : $\quad s$-Butyl 4-((4-amino-6-(3-(4-cyclopropyl-2-fluorobenzamido)-5-fluoro-2methylphenyl)pyrimidin-5-yl)oxy)piperidine-1-carboxylate (S-57a)

To a solution of S-56a (212 mg, $0.613 \mathrm{mmol})$ in DME $(8.0 \mathrm{~mL})$ and water $(1.1 \mathrm{~mL})$ was added 38 (278 mg, $0.674 \mathrm{mmol}$ ) followed by aqueous $\mathrm{Na}_{2} \mathrm{CO}_{3}$ solution (1 M, $1.84 \mathrm{~mL}, 1.84 \mathrm{mmol}$ ). After purging with argon for $10 \mathrm{~min}, \mathrm{PdCl}_{2}\left(\mathrm{PPh}_{3}\right)_{2}(21.50 \mathrm{mg}, 0.031 \mathrm{mmol})$ was added and the reaction 
mixture was stirred at $110{ }^{\circ} \mathrm{C}$ for $10 \mathrm{~min}$ under microwave irradiation. More 38 (152 mg, 0.368 mmol), aqueous $\mathrm{Na}_{2} \mathrm{CO}_{3}$ solution $(1 \mathrm{M}, 1.0 \mathrm{~mL}, 1.00 \mathrm{mmol})$, and $\mathrm{PdCl}_{2}\left(\mathrm{PPh}_{3}\right)_{2}(20 \mathrm{mg}, 0.028$ mmol) were added and the heating cycle was repeated. The mixture was diluted with saturated aqueous $\mathrm{NaHCO}_{3}$ solution and extracted with EtOAc. The organic layer was washed with water and brine, dried over $\mathrm{MgSO}_{4}$, filtered and concentrated. The residue was purified by column chromatography ( $\mathrm{SiO}_{2}$; DCM/EtOAc gradient) to afford a grey foam. The residue was re-purified by preparative HPLC (Xterra; water/acetonitrile gradient) to afford S-57a as a white solid. Yield: $53 \%$. [ES-MS] (ESI+): $\mathrm{m} / \mathrm{z}$ calcd for $\mathrm{C}_{31} \mathrm{H}_{36} \mathrm{~F}_{2} \mathrm{~N}_{5} \mathrm{O}_{4}[\mathrm{M}+\mathrm{H}]^{+}$, 580.3; found, 580.2.

Step 3 : N-(3-(6-Amino-5-(piperidin-4-yloxy)pyrimidin-4-yl)-5-fluoro-2-methylphenyl)-4cyclopropyl-2-fluorobenzamide (S-58a)

Crude S-58a was obtained following the procedure described for S-31 substituting S-57a for S-30. [ES-MS] (ESI+): $\mathrm{m} / \mathrm{z}$ calcd for $\mathrm{C}_{26} \mathrm{H}_{28} \mathrm{~F}_{2} \mathrm{~N}_{5} \mathrm{O}_{2}[\mathrm{M}+\mathrm{H}]^{+}$, 480.2; found, 480.2.

Step 4 : N-(3-(5-((1-Acryloylpiperidin-4-yl)oxy)-6-aminopyrimidin-4-yl)-5-fluoro-2-methylphenyl)-4-cyclopropyl-2-fluorobenzamide (20)

To a solution of acrylic acid $(0.037 \mathrm{~mL}, 0.546 \mathrm{mmol})$ and DIPEA $(0.191 \mathrm{~mL}, 1.092 \mathrm{mmol})$ in DMF (2.0 mL) was added T3P (50 \% in DMF, $0.276 \mathrm{~mL}, 0.473 \mathrm{mmol}$ ). The mixture was stirred at RT for $30 \mathrm{~min}$. This solution was added to a solution of crude S-58a (194 mg, $0.364 \mathrm{mmol}$ ) in DMF $(4.0 \mathrm{~mL})$ at $0{ }^{\circ} \mathrm{C}$. The reaction mixture was stirred at $0{ }^{\circ} \mathrm{C}$ for $1 \mathrm{hr}$. It was then diluted with water and extracted with EtOAc. The organic layer was washed with water and brine (2x), dried over $\mathrm{MgSO}_{4}$, filtered and concentrated. The residue was purified by column chromatography ( $\mathrm{SiO}_{2}$; (DCM with $2 \%$ ammonia)/MeOH gradient) to afford 20 as a white solid after trituration with diethyl ether. Yield: $47 \%$ over 2 steps. [ES-MS] (ESI+): m/z calcd for $\mathrm{C}_{29} \mathrm{H}_{30} \mathrm{~F}_{2} \mathrm{~N}_{5} \mathrm{O}_{3}[\mathrm{M}+$ $\mathrm{H}^{+}$, 534.2; found, 534.2. ${ }^{1} \mathrm{H}$ NMR (400 MHz, DMSO-d 6 ) $\delta 9.89(\mathrm{~s}, 1 \mathrm{H}), 8.20(\mathrm{~s}, 1 \mathrm{H}), 7.69-7.59$ 
(m, 1H), $7.57-7.43$ (m, 1H), $7.13-7.00$ (m, 3H), 6.91 (s, br, 2H), 6.72 (dd, 1H), 6.03 (d, 1H), 5.61 (dd, 1H), $3.78-3.59$ (m, 3H), $3.08-2.97$ (m, 1H), $2.91-2.80$ (m, 1H), $2.10-1.98$ (m, 4H), $1.61-1.32(\mathrm{~m}, 4 \mathrm{H}), 1.12-1.01(\mathrm{~m}, 2 \mathrm{H}), 0.83-0.75(\mathrm{~m}, 2 \mathrm{H}) .{ }^{13} \mathrm{C}$ NMR (101 MHz, DMSO-d 6 ) $\delta$ 164.49, 163.16, 163.14, 161.25, 160.93, 159.84, 158.79, 158.53, 154.14, 154.12, 153.27, 151.12, 151.04, 139.52, 139.43, 138.35, 138.24, 134.62, 130.73, 130.70, 128.76, 127.59, 127.49, 127.46, 122.02, 121.99, 121.08, 120.94, 113.80, 113.59, 113.17, 112.94, 112.68, 78.00, 42.67, 31.94, 30.86, 15.58, 14.87, 10.96. HRMS (ESI+): m/z calcd for $\mathrm{C}_{29} \mathrm{H}_{30} \mathrm{~F}_{2} \mathrm{~N}_{5} \mathrm{O}_{3}[\mathrm{M}+\mathrm{H}]+$, 534.23112; found, 534.23132.

(R)-N-(3-(5-((1-Acryloylpyrrolidin-2-yl)methoxy)-6-aminopyrimidin-4-yl)-5-fluoro-2methylphenyl)-4-cyclopropyl-2-fluorobenzamide (21)

Step 1: tert-Butyl (R)-2-(((4-amino-6-chloropyrimidin-5-yl)oxy)methyl)pyrrolidine-1carboxylate (S-56b)

DIAD (4.51 ml, $23.19 \mathrm{mmol}$ ) was added dropwise to a suspension of 41 (1.50 g, $9.28 \mathrm{mmol}$ ), N-Boc-D-prolinol (3.73 g, 18.55 mmol) and SMOPEX-301 (1mmol/g, 22.17 g, $22.17 \mathrm{mmol}$ ) in THF (84 ml). The reaction mixture was stirred at $60{ }^{\circ} \mathrm{C}$ for $6 \mathrm{~h}$, then filtered through a pad of Celite. The filtrate was concentrated and purified by column chromatography ( $\mathrm{SiO}_{2}$; cyclohexane/EtOAc gradient) to afford S-56b as an orange oil (purity $60 \%$ ). No further purification. [ES-MS] (ESI+): m/z calcd for $\mathrm{C}_{14} \mathrm{H}_{22} \mathrm{ClN}_{4} \mathrm{O}_{3}[\mathrm{M}+\mathrm{H}]^{+}$, 329.1; found, 329.2. 
Step 2: tert-Butyl (R)-2-((4-amino-6-(3-(4-cyclopropyl-2-fluorobenzamido)-5-fluoro-2methylphenyl)pyrimidin-5-yl)oxy)methyl)pyrrolidine-1-carboxylate (S-57b)

The title compound S-57b was obtained following the procedure described for S-57a substituting S-56b for S-56a. Yield: $81 \%$ over 2 steps. [ES-MS] (ESI+): m/z calcd for $\mathrm{C}_{31} \mathrm{H}_{36} \mathrm{~F}_{2} \mathrm{~N}_{5} \mathrm{O}_{4}[\mathrm{M}+\mathrm{H}]^{+}$, 580.3; found, 580.4.

Step 3 : (R)-N-(3-(6-Amino-5-(pyrrolidin-2-ylmethoxy)pyrimidin-4-yl)-5-fluoro-2-methylphenyl)-4-cyclopropyl-2-fluorobenzamide (S-58b)

The title compound S-58b was obtained following the procedure described for S-31 substituting S-57b for S-30. Yield: $86 \%$. [ES-MS] (ESI+): $\mathrm{m} / \mathrm{z}$ calcd for $\mathrm{C}_{26} \mathrm{H}_{28} \mathrm{~F}_{2} \mathrm{~N}_{5} \mathrm{O}_{2}[\mathrm{M}+\mathrm{H}]^{+}$, 480.2; found, 480.3.

Step 4 : (R)-N-(3-(5-((1-Acryloylpyrrolidin-2-yl)methoxy)-6-aminopyrimidin-4-yl)-5-fluoro2-methylphenyl)-4-cyclopropyl-2-fluorobenzamide (21)

The title compound $\mathbf{2 1}$ was obtained as a white solid following the procedure described for $\mathbf{2 0}$ substituting S-58b for S-58a. Yield: $36 \%$. [ES-MS] (ESI+): m/z calcd for $\mathrm{C}_{29} \mathrm{H}_{30} \mathrm{~F}_{2} \mathrm{~N}_{5} \mathrm{O}_{3}[\mathrm{M}+\mathrm{H}]^{+}$, 534.2; found, 534.3. ${ }^{1} \mathrm{H}$ NMR (400 MHz, DMSO-d 6 ) rotamers $\delta 9.80$ and 9.75 (2s, total $\left.1 \mathrm{H}\right), 8.26$ - 8.14 (m, 1H), $7.73-7.60$ (m, 1H), $7.61-7.48$ (m, 1H), $7.17-6.89$ (m, 5H), 6.55 - 6.40 (m, 1H), $6.15-6.02(\mathrm{~m}, 1 \mathrm{H}), 5.67-5.52(\mathrm{~m}, 1 \mathrm{H}), 4.24-4.11$ and $4.09-3.97$ (2m, total 1H), $3.69-$ 3.58 and $3.13-3.01(2 \mathrm{~m}$, total $1 \mathrm{H}), 3.51-3.18(\mathrm{~m}, 3 \mathrm{H}$, overlapping with water), $2.10-1.94(\mathrm{~m}$, 4H), $1.77-1.50$ and $1.47-1.31(2 \mathrm{~m}$, total 4H), $1.14-0.99(\mathrm{~m}, 2 \mathrm{H}), 0.84-0.73(\mathrm{~m}, 2 \mathrm{H})$. HRMS (ESI+): $\mathrm{m} / \mathrm{z}$ calcd for $\mathrm{C}_{29} \mathrm{H}_{30} \mathrm{~F}_{2} \mathrm{~N}_{5} \mathrm{O}_{3}[\mathrm{M}+\mathrm{H}]+$, 534.23112; found, 534.2312. 
(S)-N-(3-(5-((1-Acryloylpyrrolidin-2-yl)methoxy)-6-aminopyrimidin-4-yl)-5-fluoro-2-

methylphenyl)-4-cyclopropyl-2-fluorobenzamide (22)

Step 1: tert-Butyl (S)-2-(((4-amino-6-chloropyrimidin-5-yl)oxy)methyl)pyrrolidine-1carboxylate (S-56c)

The title compound S-56c (purity 66 \%) was obtained following the procedure described for S-56b substituting N-Boc-L-prolinol for N-Boc-D-prolinol. [ES-MS] (ESI+): $\mathrm{m} / \mathrm{z}$ calcd for $\mathrm{C}_{14} \mathrm{H}_{22} \mathrm{ClN}_{4} \mathrm{O}_{3}[\mathrm{M}+\mathrm{H}]^{+}$, 329.1; found, 329.2.

Step 2: tert-Butyl (S)-2-((4-amino-6-(3-(4-cyclopropyl-2-fluorobenzamido)-5-fluoro-2methylphenyl)pyrimidin-5-yl)oxy)methyl)pyrrolidine-1-carboxylate (S-57c)

The title compound S-57c was obtained following the procedure described for S-57a substituting S-56c for S-56a. Yield: $60 \%$ over 2 steps. [ES-MS] (ESI+): $\mathrm{m} / \mathrm{z}$ calcd for $\mathrm{C}_{31} \mathrm{H}_{36} \mathrm{~F}_{2} \mathrm{~N}_{5} \mathrm{O}_{4}[\mathrm{M}+$ H] $]^{+}$, 580.3; found, 580.3.

Step 3: (S)-N-(3-(6-Amino-5-(pyrrolidin-2-ylmethoxy)pyrimidin-4-yl)-5-fluoro-2-methylphenyl)-4-cyclopropyl-2-fluorobenzamide (S-58c)

The title compound S-58c was obtained following the procedure described for S-31 substituting S-57c for S-30. Yield: $97 \%$. [ES-MS] (ESI+): $\mathrm{m} / \mathrm{z}$ calcd for $\mathrm{C}_{26} \mathrm{H}_{28} \mathrm{~F}_{2} \mathrm{~N}_{5} \mathrm{O}_{2}[\mathrm{M}+\mathrm{H}]^{+}$, 480.2; found, 480.3.

Step $4:$ (S)-N-(3-(5-((1-Acryloylpyrrolidin-2-yl)methoxy)-6-aminopyrimidin-4-yl)-5-fluoro2-methylphenyl)-4-cyclopropyl-2-fluorobenzamide (22)

The title compound $\mathbf{2 2}$ was obtained as a white solid following the procedure described for $\mathbf{2 0}$ substituting S-58c for S-58a. Yield: $44 \%$. [ES-MS] (ESI+): m/z calcd for $\mathrm{C}_{29} \mathrm{H}_{30} \mathrm{~F}_{2} \mathrm{~N}_{5} \mathrm{O}_{3}[\mathrm{M}+\mathrm{H}]^{+}$, 534.2; found, 534.3. ${ }^{1} \mathrm{H}$ NMR (400 MHz, DMSO-d 6 ) rotamers $\delta 9.81$ and 9.75 (2s, total $\left.1 \mathrm{H}\right), 8.23$ - 8.17 (m, 1H), $7.72-7.60$ (m, 1H), $7.61-7.50$ (m, 1H), 7.18 - 6.89 (m, 5H), 6.47 (dd, 1H), 6.14 
- $6.03(\mathrm{~m}, 1 \mathrm{H}), 5.66-5.52(\mathrm{~m}, 1 \mathrm{H}), 4.23-4.14$ and $4.09-3.99(2 \mathrm{~m}$, total $1 \mathrm{H}), 3.68-3.60$ and $3.12-3.01$ (2m, total 1H), $3.49-3.18$ (m, 3H, overlapping with water), $2.08-1.96(\mathrm{~m}, 4 \mathrm{H}), 1.76$ - 1.52 and $1.46-1.32$ (2m, total 4H), $1.10-1.01(\mathrm{~m}, 2 \mathrm{H}), 0.84-0.74(\mathrm{~m}, 2 \mathrm{H}) .{ }^{13} \mathrm{C}$ NMR $(126$ MHz, DMSO- $\left.\mathrm{d}_{6}\right)$ rotamers $\delta 163.80,163.41,162.63,160.61,158.56,158.32,158.17,155.57$, 154.02, 153.48, 153.35, 152.85, 138.62, 138.54, 138.33, 138.26, 137.87, 137.73, 135.82, 135.15, 130.32, 130.24, 129.65, 129.31, 126.86, 126.68, 126.35, 121.57, 121.52, 112.95, 112.83, 112.76, 112.67, 112.65, 112.49, 112.47, 112.18, 112.00, 111.84, 99.49, 71.53, 71.41, 55.92, 55.11, 46.57, 45.21, 27.42, 26.52, 23.26, 20.72, 15.07, 14.25, 10.45. HRMS (ESI+): m/z calcd for $\mathrm{C}_{29} \mathrm{H}_{30} \mathrm{~F}_{2} \mathrm{~N}_{5} \mathrm{O}_{3}$ $[\mathrm{M}+\mathrm{H}]+$, 534.23112; found, 534.23132.

(S)-N-(3-(5-((1-Acryloylazetidin-2-yl)methoxy)-6-aminopyrimidin-4-yl)-5-fluoro-2-methylphenyl)-4-cyclopropyl-2-fluorobenzamide (23)

Step 1 : tert-Butyl (S)-2-((4-amino-6-chloropyrimidin-5-yl)oxy)methyl)azetidine-1carboxylate (S-56d)

The title compound S-56d (purity 80 \%) was obtained following the procedure described for S-56b substituting S-53 for N-Boc-D-prolinol. [ES-MS] (ESI+): m/z calcd for $\mathrm{C}_{13} \mathrm{H}_{20} \mathrm{ClN}_{4} \mathrm{O}_{3}[\mathrm{M}+\mathrm{H}]^{+}$, 315.1; found, 315.1.

Step 2: tert-Butyl (S)-2-((4-amino-6-(3-(4-cyclopropyl-2-fluorobenzamido)-5-fluoro-2methylphenyl)pyrimidin-5-yl)oxy)methyl)azetidine-1-carboxylate (S-57d)

The title compound S-57d was obtained following the procedure described for S-57a substituting S-56d for S-56a. Yield: 28 \% over 2 steps. [ES-MS] (ESI+): m/z calcd for $\mathrm{C}_{30} \mathrm{H}_{34} \mathrm{~F}_{2} \mathrm{~N}_{5} \mathrm{O}_{4}[\mathrm{M}+$ $\mathrm{H}]^{+}$, 566.3; found, 566.2. 
Step 3: (S)-N-(3-(6-Amino-5-(azetidin-2-ylmethoxy)pyrimidin-4-yl)-5-fluoro-2-methylphenyl)-4-cyclopropyl-2-fluorobenzamide (S-58d)

The title compound S-58d was obtained as TFA salt following the procedure described for $\mathbf{S - 3 1}$ substituting S-57d for S-30. [ES-MS] (ESI+): m/z calcd for $\mathrm{C}_{25} \mathrm{H}_{26} \mathrm{~F}_{2} \mathrm{~N}_{5} \mathrm{O}_{2}[\mathrm{M}+\mathrm{H}]^{+}$, 466.2; found, 466.1.

Step 4 : (S)-N-(3-(5-((1-Acryloylazetidin-2-yl)methoxy)-6-aminopyrimidin-4-yl)-5-fluoro-2methylphenyl)-4-cyclopropyl-2-fluorobenzamide (23)

The title compound $\mathbf{2 3}$ was obtained as a white solid following the procedure described for $\mathbf{2 0}$ substituting S-58d for S-58a. Yield: $67 \%$ over 2 steps. [ES-MS] (ESI+): $\mathrm{m} / \mathrm{z}$ calcd for $\mathrm{C}_{28} \mathrm{H}_{28} \mathrm{~F}_{2} \mathrm{~N}_{5} \mathrm{O}_{3}[\mathrm{M}+\mathrm{H}]^{+}$, 520.2; found, 520.2. ${ }^{1} \mathrm{H}$ NMR (400 MHz, DMSO-d $\mathrm{d}_{6}$ ) rotamers $\delta 9.82$ and $9.75(2 \mathrm{~s}$, total $1 \mathrm{H}), 8.21$ and $8.19(2 \mathrm{~s}$, total $1 \mathrm{H}), 7.70-7.60(\mathrm{~m}, 1 \mathrm{H}), 7.59-7.47(\mathrm{~m}, 1 \mathrm{H}), 7.18-$ $6.91(\mathrm{~m}, 5 \mathrm{H}), 6.29-6.17$ and $6.16-5.97$ (2m, total 2H), $5.71-5.62$ and $5.59-5.49$ (2m, total 1H), $4.52-4.42$ and $4.42-4.33(2 \mathrm{~m}$, total $1 \mathrm{H}), 4.04-3.91$ and $3.90-3.83$ (2m, total $2 \mathrm{H}$ ), 3.82 - 3.68 and $3.67-3.52(2 \mathrm{~m}$, total 2H), $2.14-1.97(\mathrm{~m}, 2 \mathrm{H})$ overlapping with 2.05 and 2.01 (2s, total 3H), $1.73-1.62(\mathrm{~m}, 1 \mathrm{H}), 1.08-1.02(\mathrm{~m}, 2 \mathrm{H}), 0.83-0.75(\mathrm{~m}, 2 \mathrm{H}) .{ }^{13} \mathrm{C}$ NMR (101 MHz, DMSO-d 6 ) rotamers $\delta 165.40,165.30,162.55,162.28,160.99,160.83,160.42,160.34,158.66$, 158.61, 158.52, 158.36, 158.02, 157.94, 153.61, 153.34, 152.85, 151.03, 150.95, 150.76, 150.68, 141.60, 141.37, 138.69, 138.60, 138.29, 138.20, 137.76, 137.69, 137.65, 137.58, 135.99, 135.10, 130.47, 130.28, 126.19, 126.00, 122.66, 122.47, 121.57, 120.43, 120.29, 119.93, 119.79, 112.77, 112.68, 112.53, 112.46, 112.22, 111.99, 111.91, 111.67, 70.30, 68.70, 59.87, 48.17, 47.26, 44.96, 44.87, 35.46, 32.78, 15.08, 14.16, 14.13, 10.50, 10.47. HRMS (ESI+): $\mathrm{m} / \mathrm{z}$ calcd for $\mathrm{C}_{28} \mathrm{H}_{28} \mathrm{~F}_{2} \mathrm{~N}_{5} \mathrm{O}_{3}$ $[\mathrm{M}+\mathrm{H}]+$, 520.21547; found, 520.21576. 
(R)-N-(3-(5-((1-Acryloylazetidin-2-yl)methoxy)-6-aminopyrimidin-4-yl)-5-fluoro-2methylphenyl)-4-cyclopropyl-2-fluorobenzamide (24)

Step 1: tert-Butyl (R)-2-((4-amino-6-chloropyrimidin-5-yl)oxy)methyl)azetidine-1carboxylate (S-56e)

The title compound S-56e (purity $90 \%$ ) was obtained following the procedure described for S-56b substituting S-55 for N-Boc-D-prolinol. [ES-MS] (ESI+): m/z calcd for $\mathrm{C}_{13} \mathrm{H}_{20} \mathrm{ClN}_{4} \mathrm{O}_{3}[\mathrm{M}+\mathrm{H}]^{+}$, 315.1; found, 315.1.

Step 2: tert-Butyl (R)-2-((4-amino-6-(3-(4-cyclopropyl-2-fluorobenzamido)-5-fluoro-2methylphenyl)pyrimidin-5-yl)oxy)methyl)azetidine-1-carboxylate (S-57e)

The title compound S-57e was obtained following the procedure described for S-57a substituting S-56e for S-56a. Yield: $33 \%$ over 2 steps. [ES-MS] (ESI+): m/z calcd for $\mathrm{C}_{30} \mathrm{H}_{34} \mathrm{~F}_{2} \mathrm{~N}_{5} \mathrm{O}_{4}[\mathrm{M}+$ H] $]^{+}$, 566.3; found, 566.3.

Step 3: (R)-N-(3-(6-Amino-5-(azetidin-2-ylmethoxy)pyrimidin-4-yl)-5-fluoro-2-methylphenyl)-4-cyclopropyl-2-fluorobenzamide (S-58e)

The title compound S-58e was obtained as TFA salt following the procedure described for S-31 substituting S-57e for S-30. Yield: $91 \%$. [ES-MS] (ESI+): $\mathrm{m} / \mathrm{z}$ calcd for $\mathrm{C}_{25} \mathrm{H}_{26} \mathrm{~F}_{2} \mathrm{~N}_{5} \mathrm{O}_{2}[\mathrm{M}+\mathrm{H}]^{+}$, 466.2; found, 466.3.

Step 4 : (R)-N-(3-(5-((1-Acryloylazetidin-2-yl)methoxy)-6-aminopyrimidin-4-yl)-5-fluoro-2methylphenyl)-4-cyclopropyl-2-fluorobenzamide (24)

The title compound $\mathbf{2 4}$ was obtained as a white solid following the procedure described for $\mathbf{2 0}$ substituting S-58e for S-58a. Yield: $58 \%$. [ES-MS] (ESI+): m/z calcd for $\mathrm{C}_{28} \mathrm{H}_{28} \mathrm{~F}_{2} \mathrm{~N}_{5} \mathrm{O}_{3}[\mathrm{M}+\mathrm{H}]^{+}$, 520.2; found, 520.3. ${ }^{1} \mathrm{H}$ NMR (400 MHz, DMSO-d 6 ) rotamers $\delta 9.82$ and $9.76(2 \mathrm{~s}$, total $1 \mathrm{H}), 8.22$ and $8.20(2 \mathrm{~s}$, total 1H), $7.70-7.59(\mathrm{~m}, 1 \mathrm{H}), 7.60-7.47(\mathrm{~m}, 1 \mathrm{H}), 7.18-6.91(\mathrm{~m}, 5 \mathrm{H}), 6.30-6.16$ 
and $6.16-5.97(2 \mathrm{~m}$, total $2 \mathrm{H}), 5.72-5.61$ and $5.60-5.49(2 \mathrm{~m}$, total $1 \mathrm{H}), 4.52-4.42$ and $4.42-$ $4.33(2 \mathrm{~m}$, total $1 \mathrm{H}), 4.04-3.91$ and $3.90-3.83(2 \mathrm{~m}$, total $2 \mathrm{H}), 3.81-3.68$ and $3.67-3.53(2 \mathrm{~m}$, total $2 \mathrm{H}), 2.14-1.96(\mathrm{~m}, 2 \mathrm{H})$ overlapping with 2.05 and 2.01 (2s, total $3 \mathrm{H}), 1.73-1.61(\mathrm{~m}, 1 \mathrm{H})$, $1.12-1.00(\mathrm{~m}, 2 \mathrm{H}), 0.83-0.74(\mathrm{~m}, 2 \mathrm{H}) .{ }^{13} \mathrm{C}$ NMR (101 MHz, DMSO-d 6 ) rotamers $\delta 165.38$, 164.68, 162.61, 160.78, 160.35, 158.58, 158.51, 158.31, 157.96, 153.86, 153.45, 153.18, 153.02, 150.66, 150.58, 138.46, 138.37, 137.76, 137.65, 135.55, 135.40, 130.24, 127.00, 126.74, 126.45, 126.34, 126.23, 121.53, 120.53, 120.39, 113.05, 112.83, 112.68, 112.45, 112.14, 111.90, 73.51, 71.95, 60.13, 59.56, 47.90, 45.48, 18.72, 18.00, 15.07, 14.27, 10.45. HRMS (ESI+): m/z calcd for $\mathrm{C}_{28} \mathrm{H}_{28} \mathrm{~F}_{2} \mathrm{~N}_{5} \mathrm{O}_{3}[\mathrm{M}+\mathrm{H}]+$, 520.21547; found, 520.21582 .

\section{N-(3-(6-Amino-5-(3-(N-methylacrylamido)propoxy)pyrimidin-4-yl)-5-fluoro-2-methyl- phenyl)-4-cyclopropyl-2-fluorobenzamide (26)}

Step 1: tert-Butyl (3-((4-amino-6-chloropyrimidin-5-yl)oxy)propyl)(methyl)carbamate (S-56f)

The title compound S-56f (purity 80 \%) was obtained following the procedure described for S-56b substituting N-Boc-N-methyl-3-aminopropanol for N-Boc-D-prolinol. [ES-MS] (ESI+): m/z calcd for $\mathrm{C}_{13} \mathrm{H}_{22} \mathrm{ClN}_{4} \mathrm{O}_{3}[\mathrm{M}+\mathrm{H}]^{+}$, 317.1; found, 317.2.

Step 2 : tert-Butyl (3-((4-amino-6-(3-(4-cyclopropyl-2-fluorobenzamido)-5-fluoro-2-methylphenyl)pyrimidin-5-yl)oxy)propyl)(methyl)carbamate (S-57f)

The title compound S-57f was obtained following the procedure described for S-57a substituting S-56f for S-56a. Yield: 19 \% over 2 steps. [ES-MS] (ESI+): m/z calcd for $\mathrm{C}_{30} \mathrm{H}_{36} \mathrm{~F}_{2} \mathrm{~N}_{5} \mathrm{O}_{4}[\mathrm{M}+\mathrm{H}]^{+}$, 568.3; found, 568.4. 
Step 3: N-(3-(6-Amino-5-(3-(methylamino)propoxy)pyrimidin-4-yl)-5-fluoro-2-methylphenyl)-4-cyclopropyl-2-fluorobenzamide (S-58f)

To a solution of S-57f (320 mg, $0.564 \mathrm{mmol}$ ) in $\mathrm{CH}_{2} \mathrm{Cl}_{2}(6 \mathrm{~mL})$ was added $\mathrm{HCl}$ (2 $\mathrm{M}$ in $\mathrm{Et}_{2} \mathrm{O}, 2.82$ $\mathrm{mL}, 5.64 \mathrm{mmol}$ ) and the reaction mixture was stirred at RT for $18 \mathrm{~h}$. It was then concentrated to afford crude S-58f as $\mathrm{HCl}$ salt as a beige solid. Yield: $94 \%$. [ES-MS] (ESI+): m/z calcd for $\mathrm{C}_{25} \mathrm{H}_{28} \mathrm{~F}_{2} \mathrm{~N}_{5} \mathrm{O}_{2}[\mathrm{M}+\mathrm{H}]^{+}$, 468.2; found, 468.3 .

Step 4: N-(3-(6-Amino-5-(3-(N-methylacrylamido)propoxy)pyrimidin-4-yl)-5-fluoro-2methylphenyl)-4-cyclopropyl-2-fluorobenzamide (26)

The title compound $\mathbf{2 6}$ was obtained as a white solid following the procedure described for $\mathbf{2 0}$ substituting S-58f for S-58a. Yield: $43 \%$. [ES-MS] (ESI+): m/z calcd for $\mathrm{C}_{28} \mathrm{H}_{30} \mathrm{~F}_{2} \mathrm{~N}_{5} \mathrm{O}_{3}[\mathrm{M}+\mathrm{H}]^{+}$, 522.2; found, 522.4. ${ }^{1} \mathrm{H}$ NMR (400 MHz, DMSO-d6) rotamers $\delta 9.88-9.77$ (m, 1H), $8.22-8.15$ (m, 1H), $7.69-7.60(\mathrm{~m}, 1 \mathrm{H}), 7.58-7.45(\mathrm{~m}, 1 \mathrm{H}), 7.15-6.92(\mathrm{~m}, 5 \mathrm{H}), 6.73-6.61$ and $6.61-$ $6.49(2 \mathrm{~m}$, total $1 \mathrm{H}), 6.09-5.97(\mathrm{~m}, 1 \mathrm{H}), 5.67-5.54(\mathrm{~m}, 1 \mathrm{H}), 3.52-3.45$ and $3.43-3.36(2 \mathrm{~m}$, total 2H), $3.26-3.19$ and $3.13-3.06$ (2m, total 2H), 2.87 and 2.72 (2s, total 3H), $2.09-1.97$ (m, 4H), $1.69-1.54$ (m, 2H), $1.09-1.01$ (m, 2H), $0.83-0.75$ (m, 2H). ${ }^{13} \mathrm{C}$ NMR (151 MHz, DMSO$\left.\mathrm{d}_{6}\right)$ rotamers $\delta 165.35,164.99,162.59,160.39,160.01,159.95,158.78,158.74,158.66,158.41$, 158.36, 153.51, 153.49, 152.88, 152.84, 150.66, 150.63, 150.61, 138.75, 138.69, 138.68, 138.62, 137.85, 137.78, 137.77, 137.69, 135.83, 135.78, 130.24, 130.22, 128.41, 128.06, 127.13, 126.86, 126.49, 126.48, 126.46, 121.53, 121.52, 120.49, 120.46, 120.39, 120.36, 113.05, 112.94, 112.91, 112.79, 112.65, 112.50, 112.14, 112.05, 111.98, 111.90, 69.72, 69.68, 45.73, 43.65, 34.56, 33.11, 28.67, 26.99, 15.08, 15.07, 14.35, 14.26, 10.46. HRMS (ESI+): $\mathrm{m} / \mathrm{z}$ calcd for $\mathrm{C}_{28} \mathrm{H}_{30} \mathrm{~F}_{2} \mathrm{~N}_{5} \mathrm{O}_{3}[\mathrm{M}+$ H]+, 522.23112; found, 522.23114. 
N-(3-(6-amino-5-(2-(N-ethylacrylamido)ethoxy)pyrimidin-4-yl)-5-fluoro-2-methylphenyl)4-cyclopropyl-2-fluorobenzamide (27)

Step 1 : tert-Butyl (2-((4-amino-6-chloropyrimidin-5-yl)oxy)ethyl)(ethyl)carbamate (S-56g) The title compound S-56g (purity $90 \%$ ) was obtained following the procedure described for S-56b substituting N-Boc-N-ethyl-2-aminoethanol for N-Boc-D-prolinol. [ES-MS] (ESI+): m/z calcd for $\mathrm{C}_{13} \mathrm{H}_{22} \mathrm{ClN}_{4} \mathrm{O}_{3}[\mathrm{M}+\mathrm{H}]^{+}$, 317.1; found, 317.1.

Step 2: tert-Butyl (2-((4-Amino-6-(3-(4-cyclopropyl-2-fluorobenzamido)-5-fluoro-2methylphenyl)pyrimidin-5-yl)oxy)ethyl)(ethyl)carbamate (S-57g)

The title compound S-57g was obtained following the procedure described for S-57a substituting S-56g for S-56a, and aqueous $\mathrm{NaHCO}_{3}$ solution for aqueous $\mathrm{Na}_{2} \mathrm{CO}_{3}$ solution. Yield: $14 \%$ over 2 steps. [ES-MS] (ESI+): $\mathrm{m} / \mathrm{z}$ calcd for $\mathrm{C}_{30} \mathrm{H}_{36} \mathrm{~F}_{2} \mathrm{~N}_{5} \mathrm{O}_{4}[\mathrm{M}+\mathrm{H}]^{+}$, 568.3; found, 568.2.

Step 3 : N-(3-(6-Amino-5-(2-(ethylamino)ethoxy)pyrimidin-4-yl)-5-fluoro-2-methylphenyl)4-cyclopropyl-2-fluorobenzamide (S-58g)

The title compound S-58g was obtained as TFA salt following the procedure described for S-31 substituting S-57g for S-30. [ES-MS] (ESI+): m/z calcd for $\mathrm{C}_{25} \mathrm{H}_{28} \mathrm{~F}_{2} \mathrm{~N}_{5} \mathrm{O}_{2}[\mathrm{M}+\mathrm{H}]^{+}, 468.2$; found, 468.3.

Step 4 : N-(3-(6-amino-5-(2-(N-ethylacrylamido)ethoxy)pyrimidin-4-yl)-5-fluoro-2-methylphenyl)-4-cyclopropyl-2-fluorobenzamide (27)

The title compound $\mathbf{2 7}$ was obtained as a white solid following the procedure described for $\mathbf{2 0}$ substituting S-58g for S-58a. Yield: $28 \%$ over 2 steps. [ES-MS] (ESI+): m/z calcd for $\mathrm{C}_{28} \mathrm{H}_{30} \mathrm{~F}_{2} \mathrm{~N}_{5} \mathrm{O}_{3}[\mathrm{M}+\mathrm{H}]^{+}$, 522.2; found, 522.2. ${ }^{1} \mathrm{H}$ NMR (400 MHz, Chloroform-d) rotamers $\delta 8.63$ - 8.52 (m, br, 1H), 8.35 (s, br, 1H), $8.18-8.04$ (m, 2H), $7.08-7.00$ (m, 1H), $6.99-6.92(\mathrm{~m}, 1 \mathrm{H})$, $6.90-6.82$ (m, 1H), $6.61-6.49$ (m, 1H), $6.42-6.32$ (m, 1H), $5.77-5.68$ (m, 1H), 3.59 (s, br, 
4H), $3.37-3.26(\mathrm{~m}, 2 \mathrm{H}), 2.21-2.16$ and $2.13(2 \mathrm{~s}$, total 3H), $2.03-1.91(\mathrm{~m}, 1 \mathrm{H}), 1.17-1.03(\mathrm{~m}$, 5H), $0.85-0.75(\mathrm{~m}, 2 \mathrm{H})$, two exchangeable protons not observed. ${ }^{13} \mathrm{C}$ NMR (101 MHz, DMSO$\left.\mathrm{d}_{6}\right)$ rotamers $\delta 165.13,164.74,162.58,162.39,160.92,160.81,160.48,160.35,158.65,158.45$, 158.34, 158.08, 157.95, 153.72, 153.31, 153.26, 152.82, 150.89, 150.81, 150.71, 150.62, 138.68, 138.60, 138.30, 138.21, 137.83, 137.72, 137.62, 136.09, 135.24, 130.37, 130.26, 128.36, 128.08, 127.16, 126.97, 126.08, 125.94, 121.56, 120.48, 120.34, 120.16, 120.02, 112.78, 112.73, 112.68, 112.57, 112.49, 112.46, 112.03, 111.89, 111.79, 111.66, 70.54, 69.32, 45.40, 45.13, 42.15, 15.08, 14.40, 14.23, 14.15, 12.46, 10.47. HRMS (ESI+): $\mathrm{m} / \mathrm{z}$ calcd for $\mathrm{C}_{28} \mathrm{H}_{30} \mathrm{~F}_{2} \mathrm{~N}_{5} \mathrm{O}_{3}[\mathrm{M}+\mathrm{H}]+$, 522.23112; found, 522.23108.

\section{N-(3-(6-Amino-5-(2-(N-methylpropionamido)ethoxy)pyrimidin-4-yl)-5-fluoro-2-methyl- phenyl)-4-cyclopropyl-2-fluorobenzamide (32)}

To a solution of propionic acid (S-63) $(0.100 \mathrm{~mL}, 1.339 \mathrm{mmol})$ in DMF $(2.5 \mathrm{~mL})$ was added DIPEA (0.400 mL, $2.290 \mathrm{mmol})$ followed by T3P (50\% in DMF) (0.700 mL, $1.199 \mathrm{mmol})$. The mixture was stirred at RT for $20 \mathrm{~min}$. A solution of 44 (410 $\mathrm{mg}, 0.779 \mathrm{mmol})$ and DIPEA (0.400 $\mathrm{mL}, 2.290 \mathrm{mmol})$ in DMF (2.5 mL) was then added dropwise to the above solution cooled to $0{ }^{\circ} \mathrm{C}$. The reaction mixture was stirred at RT for 40 minutes. It was then diluted with EtOAc and washed with saturated aqueous $\mathrm{NaHCO}_{3}$ solution. The aqueous layer was back-extracted with a mixture of EtOAc/THF. The combined organic layers were washed with brine, dried over $\mathrm{MgSO}_{4}$, filtered and concentrated. The residue was triturated with cold $\mathrm{Et}_{2} \mathrm{O}$. The white solid was filtered off and dried in vacuo to afford 32. Yield: $94 \%$. [ES-MS] (ESI+): m/z calcd for $\mathrm{C}_{27} \mathrm{H}_{30} \mathrm{~F}_{2} \mathrm{~N}_{5} \mathrm{O}_{3}$ [M $+\mathrm{H}^{+}$, 510.2; found, 510.3. ${ }^{1} \mathrm{H}$ NMR (400 MHz, DMSO-d $)$ rotamers $\delta 9.82-9.76$ and $9.61-9.56$ (2m, total $1 \mathrm{H}), 8.20$ and 8.17 (2s, total $1 \mathrm{H}), 7.71$ and $7.65(2 \mathrm{t}$, total $1 \mathrm{H}), 7.61-7.51(\mathrm{~m}, 1 \mathrm{H}), 7.13$ 
- 6.93 (m, 5H), $3.55-3.49(\mathrm{~m}, 2 \mathrm{H}), 3.43-3.36(\mathrm{~m}, 2 \mathrm{H}), 2.71$ and 2.41 (2s, total 3H), 2.14 (q, 2H), $2.07-1.95(\mathrm{~m}, 1 \mathrm{H})$ overlapping with 2.02 and $1.98(2 \mathrm{~s}$, total $3 \mathrm{H}), 1.09-1.01(\mathrm{~m}, 2 \mathrm{H}), 0.93$ -0.85 (m, 3H), $0.84-0.75(\mathrm{~m}, 2 \mathrm{H}) .{ }^{13} \mathrm{C}$ NMR (101 MHz, DMSO-d 6 ) rotamers $\delta$ 172.85, 162.60, 162.37, 160.94, 160.80, 160.48, 160.35, 158.67, 158.47, 158.33, 158.08, 157.96, 153.84, 153.31, 152.82, 150.92, 150.83, 150.71, 150.63, 138.77, 138.68, 138.35, 138.27, 137.82, 137.75, 137.71, 137.64, 135.97, 135.27, 130.41, 130.26, 126.11, 125.92, 121.55, 120.48, 120.34, 120.10, 119.96, 112.79, 112.73, 112.68, 112.58, 112.50, 112.45, 112.13, 111.89, 111.71, 111.47, 70.47, 68.67, 48.12, 47.08, 35.20, 32.26, 25.63, 25.15, 15.08, 14.11, 10.46, 9.30, 8.96. HRMS (ESI+): m/z calcd for $\mathrm{C}_{27} \mathrm{H}_{30} \mathrm{~F}_{2} \mathrm{~N}_{5} \mathrm{O}_{3}[\mathrm{M}+\mathrm{H}]+$, 510.23112; found, 510.23151 .

The title compounds $\mathbf{2 8}$ to $\mathbf{3 1}$ were obtained following the procedure described for $\mathbf{3 2}$ substituting S-59 to S-62 for S-63, accordingly.

(E)-N-(3-(6-Amino-5-(2-(N-methylbut-2-enamido)ethoxy)pyrimidin-4-yl)-5-fluoro-2-

methylphenyl)-4-cyclopropyl-2-fluorobenzamide (28): Yield: 69 \%. [ES-MS] (ESI+): m/z calcd for $\mathrm{C}_{28} \mathrm{H}_{30} \mathrm{~F}_{2} \mathrm{~N}_{5} \mathrm{O}_{3}[\mathrm{M}+\mathrm{H}]^{+}$, 522.2; found, 522.2. ${ }^{1} \mathrm{H}$ NMR (400 MHz, DMSO-d $\mathrm{d}_{6}$ ) rotamers $\delta 9.76$ and $9.57(2 \mathrm{~s}$, total $1 \mathrm{H}), 8.20$ and $8.17(2 \mathrm{~s}$, total $1 \mathrm{H}), 7.72$ and $7.66(2 \mathrm{t}$, total $1 \mathrm{H}), 7.61-7.48(\mathrm{~m}$, 1H), $7.19-6.90$ (m, 5H), $6.69-6.52(\mathrm{~m}, 1 \mathrm{H}), 6.39-6.22(\mathrm{~m}, 1 \mathrm{H}), 3.60-3.39(\mathrm{~m}, 4 \mathrm{H}), 2.79$ and 2.50 (overlapping with DMSO) (2s, total 3H), $2.10-1.91$ (m, total 4H), $1.82-1.74$ (m, 3H), 1.13 - $1.02(\mathrm{~m}, 2 \mathrm{H}), 0.83-0.75(\mathrm{~m}, 2 \mathrm{H}) .{ }^{13} \mathrm{C}$ NMR (101 MHz, DMSO-d $\mathrm{d}$ ) rotamers $\delta$ 166.10, 166.04, 163.06, 162.83, 161.47, 161.33, 160.93, 160.86, 159.17, 159.13, 158.54, 158.46, 154.08, 154.06, 153.80, 153.74, 153.72, 153.32, 151.47, 151.38, 151.25, 151.17, 140.82, 140.53, 139.20, 139.11, 138.83, 138.75, 138.30, 138.20, 138.09, 136.56, 135.70, 130.93, 130.90, 130.80, 130.77, 126.73, 126.36, 122.61, 122.56, 122.08, 113.31, 113.26, 113.18, 113.09, 113.05, 113.03, 112.95, 112.71, 
112.46, 112.30, 112.08, 70.83, 69.36, 48.55, 47.75, 35.86, 33.42, 18.12, 15.59, 15.58, 14.70, 14.62, 10.99. HRMS (ESI+): $\mathrm{m} / \mathrm{z}$ calcd for $\mathrm{C}_{28} \mathrm{H}_{30} \mathrm{~F}_{2} \mathrm{~N}_{5} \mathrm{O}_{3}[\mathrm{M}+\mathrm{H}]+$, 522.23112; found, 522.23114.

(E)-N-(3-(6-Amino-5-(2-(4-(dimethylamino)-N-methylbut-2-enamido)ethoxy)pyrimidin-4yl)-5-fluoro-2-methylphenyl)-4-cyclopropyl-2-fluorobenzamide (29): Yield: 59 \%. [ES-MS] (ESI+): m/z calcd for $\mathrm{C}_{30} \mathrm{H}_{35} \mathrm{~F}_{2} \mathrm{~N}_{6} \mathrm{O}_{3}[\mathrm{M}+\mathrm{H}]^{+}$, 565.3; found, 565.3. ${ }^{1} \mathrm{H}$ NMR (400 MHz, DMSO$\left.\mathrm{d}_{6}\right)$ rotamers $\delta 9.82-9.76$ and $9.58-9.50(2 \mathrm{~m}$, total $1 \mathrm{H}), 8.24-8.15(\mathrm{~m}, 1 \mathrm{H}), 7.78-7.70$ and $7.70-7.63$ (2m, total 1H), $7.62-7.50$ (m, 1H), $7.20-6.93$ (m, 5H), $6.62-6.46$ and $6.41-6.32$ (m, total 2H), $3.61-3.52(\mathrm{~m}, 2 \mathrm{H}), 3.51-3.41(\mathrm{~m}, 2 \mathrm{H}), 2.97(\mathrm{t}, 2 \mathrm{H}), 2.80$ and 2.48 (2s, total 3H), $2.14-2.06$ (m, 6H), $2.06-1.93$ (m, 4H), $1.10-1.03$ (m, 2H), $0.85-0.76$ (m, 2H). ${ }^{13} \mathrm{C}$ NMR (151 MHz, DMSO-d 6 ) rotamers $\delta 165.42,165.32,162.56,162.29,160.59,160.43,160.03,159.95$, 158.94, 158.79, 158.68, 158.62, 158.43, 158.35, 153.62, 153.36, 153.33, 152.86, 151.04, 150.98, 150.76, 150.71, 141.62, 141.40, 138.69, 138.63, 138.29, 138.23, 137.76, 137.68, 137.61, 136.00, 135.11, 130.50, 130.48, 130.30, 130.28, 126.22, 126.00, 122.67, 122.48, 121.60, 121.57, 120.42, 120.32, 119.91, 119.82, 112.80, 112.76, 112.74, 112.66, 112.62, 112.59, 112.51, 112.20, 112.05, 111.88, 111.72, 70.32, 68.71, 59.89, 48.18, 47.28, 44.98, 44.89, 35.47, 32.79, 15.09, 14.18, 14.14, 10.53, 10.48. HRMS (ESI+): $\mathrm{m} / \mathrm{z}$ calcd for $\mathrm{C}_{30} \mathrm{H}_{35} \mathrm{~F}_{2} \mathrm{~N}_{5} \mathrm{O}_{3}[\mathrm{M}+\mathrm{H}]+$, 565.27332; found, 565.27344 .

N-(3-(6-Amino-5-(2-(N-methylpropiolamido)ethoxy)pyrimidin-4-yl)-5-fluoro-2-

methylphenyl)-4-cyclopropyl-2-fluorobenzamide (30): Yield: 9 \%. [ES-MS] (ESI+): m/z calcd for $\mathrm{C}_{27} \mathrm{H}_{26} \mathrm{~F}_{2} \mathrm{~N}_{5} \mathrm{O}_{3}[\mathrm{M}+\mathrm{H}]^{+}$, 506.2; found, 506.5. ${ }^{1} \mathrm{H}$ NMR (400 MHz, DMSO-d 6 ) rotamers $\delta 9.76$ and $9.60(2 \mathrm{~d}$, total $1 \mathrm{H}), 8.19(\mathrm{~d}, 1 \mathrm{H}), 7.73-7.62(\mathrm{~m}, 1 \mathrm{H}), 7.60-7.52(\mathrm{~m}, 1 \mathrm{H}), 7.13-6.94(\mathrm{~m}$, 
5H), 4.44 and $4.33(2 \mathrm{~s}$, total $1 \mathrm{H}), 3.68-3.54(\mathrm{~m}, 3 \mathrm{H}), 3.46-3.39(\mathrm{~m}, 1 \mathrm{H}), 2.90$ and 2.50 (overlapping with DMSO) (2s, total 3H), $2.09-1.95$ (m, 4H), $1.11-1.00$ (m, 2H), $0.85-0.72$ (m, 2H). ${ }^{13} \mathrm{C}$ NMR (101 MHz, DMSO-d 6 ) rotamers $\delta 162.55,162.46,160.92,160.83,160.47$, 160.42, 158.61, 158.59, 158.45, 158.07, 158.03, 153.64, 153.62, 153.33, 153.31, 153.19, 152.93, 152.89, 152.63, 150.82, 138.54, 138.45, 137.85, 137.80, 137.75, 137.70, 135.86, 135.29, 130.41, 130.38, 130.33, 130.30, 126.18, 125.93, 121.58, 120.42, 120.28, 120.15, 120.00, 112.94, 112.81, 112.72, 112.59, 112.49, 112.29, 111.99, 82.13, 81.51, 75.87, 75.81, 69.48, 68.87, 49.68, 45.89, 36.17, 31.56, 15.09, 14.16, 14.12, 10.51, 10.49. HRMS (ESI+): $\mathrm{m} / \mathrm{z}$ calcd for $\mathrm{C}_{27} \mathrm{H}_{26} \mathrm{~F}_{2} \mathrm{~N}_{5} \mathrm{O}_{3}[\mathrm{M}+$ H]+, 506.19982; found, 506.19968.

\section{N-(3-(6-Amino-5-(2-(N-methylbut-2-ynamido)ethoxy)pyrimidin-4-yl)-5-fluoro-2-}

methylphenyl)-4-cyclopropyl-2-fluorobenzamide (31): Yield: 77 \%. [ES-MS] (ESI+): m/z calcd for $\mathrm{C}_{28} \mathrm{H}_{28} \mathrm{~F}_{2} \mathrm{~N}_{5} \mathrm{O}_{3}[\mathrm{M}+\mathrm{H}]^{+}$, 520.2; found, 520.2. ${ }^{1} \mathrm{H}$ NMR (400 MHz, Chloroform-d) rotamers $\delta$ $8.67-8.62$ and $8.62-8.57(2 \mathrm{~m}$, total $1 \mathrm{H}), 8.36$ and $8.30(2 \mathrm{~s}$, total $1 \mathrm{H}), 8.13-7.96(\mathrm{~m}, 2 \mathrm{H}), 7.03$ - $6.90(\mathrm{~m}, 2 \mathrm{H}), 6.87-6.78(\mathrm{~m}, 1 \mathrm{H}), 5.89$ and 5.46 (2s, br, total 2H), $3.71-3.64$ and $3.63-3.49$ (2m, total 4H), 3.05 and 2.79 (2s, total 3H), $2.13(\mathrm{~s}, 3 \mathrm{H}), 1.99-1.89(\mathrm{~m}, 4 \mathrm{H}), 1.14-1.03(\mathrm{~m}, 2 \mathrm{H})$, $0.83-0.72(\mathrm{~m}, 2 \mathrm{H}) .{ }^{13} \mathrm{C}$ NMR $\left(101 \mathrm{MHz}, \mathrm{DMSO}-\mathrm{d}_{6}\right)$ rotamers $\delta 162.50,160.89,160.85,160.45$, 158.59, 158.56, 158.42, 158.39, 158.05, 153.71, 153.50, 153.35, 153.28, 153.09, 152.88, 150.85, 150.78, 150.71, 138.56, 138.48, 138.39, 137.85, 137.72, 135.89, 135.37, 130.33, 126.20, 125.73, 121.57, 120.38, 120.24, 120.18, 120.04, 112.89, 112.69, 112.48, 112.19, 111.95, 111.72, 111.47, 89.13, 88.56, 73.24, 73.13, 69.62, 69.02, 49.55, 45.78, 36.13, 31.59, 15.08, 14.12, 10.48, 3.22. HRMS (ESI+): m/z calcd for $\mathrm{C}_{28} \mathrm{H}_{28} \mathrm{~F}_{2} \mathrm{~N}_{5} \mathrm{O}_{3}$ [M + H]+, 520.21547; found, 520.21582. 


\section{STRUCTURAL BIOLOGY}

\section{Co-crystal structure of BTK with compound LOU064}

If not mentioned otherwise all chemicals were bought from Sigma-Aldrich. The kinase domain of human BTK encompassing amino acids of 386-659, as well as an N-terminal hexa-histidine tag followed by an HRV-3C protease cleavage site, was over-expressed in Spodoptera frugiperda (Sf9) cells. Large-scale expression was carried out in a total culture volume of 3.2 L Sf900III medium (Gibco) distributed in two 5L-bottles. Prior to infection with recombinant baculo virus, cells were diluted to a density of $1.9 \times 10^{6} \mathrm{ml}^{-1}$. Cells were incubated with constant shaking with $90 \mathrm{rpm}$ at $27^{\circ} \mathrm{C}$ and harvested $48 \mathrm{~h}$ post infection (centrifugation at $500 \mathrm{x} \mathrm{g}$ for $20 \mathrm{~min}$ at room temperature). Cell pellets were flash frozen and stored at $-80^{\circ} \mathrm{C}$.

For protein purification, the cell pellet was thawed in lysis buffer containing $35 \mathrm{mM}$ Tris-HCL pH 8, $300 \mathrm{mM} \mathrm{NaCl}, 10 \mathrm{mM}$ imidazole, 10 \% glycerol, $2 \mathrm{mM}$ TCEP, $250 \mathrm{U}$ of benzonase (Sigma Aldrich) and complete EDTA-free protease inhibitor cocktail (Sigma Aldrich, used according to the manufacture's recommendation). Cells were lysed by sonication (3 cycles of 30 pulses at 60 $\%$ amplitude) and the lysate was cleared by centrifugation in a 30-50Ti rotor (Sorvall) at 20,000 rpm for $1 \mathrm{~h}$ at $4{ }^{\circ} \mathrm{C}$. The cleared lysate was subjected to immobilized metal affinity chromatography (IMAC) using a pre-packed Nickel Crude FF column (GE healthcare) in IMAC buffer A (35 mM Tris-HCl pH 8, $300 \mathrm{mM} \mathrm{NaCl}, 10 \mathrm{mM}$ imidazole, 10 \% glycerol, $2 \mathrm{mM}$ TCEP). The protein was eluted from the column by stepwise addition of Buffer B ( 35 mM Tris- $\mathrm{HCl}$ pH 8, $300 \mathrm{mM} \mathrm{NaCl}$, $250 \mathrm{mM}$ imidazole, 10 \% glycerol, $2 \mathrm{mM}$ TCEP) in the following way: 5 column volumes (CV) of buffer A, followed by $10 \%$ buffer B for $8 \mathrm{CV}$ and $100 \%$ buffer B for $5 \mathrm{CV} .2 \mathrm{~mL}$ fractions were collected during elution and analyzed by SDS-PAGE. Fractions containing BTK were pooled and incubated with HRV-3C protease at $4{ }^{\circ} \mathrm{C}$ for $10 \mathrm{~h}$. The cleavage products were further purified 
by anion exchange chromatography. After cleavage, the products were dialyzed against IEX buffer A (35 mM Tris-HCl pH 8, 10 \% glycerol, 2 mM TCEP) and applied to a pre-packed HiLoad MonoQ column. The column was washed with 5 CV IEX buffer A and the protein was eluted from the column by applying a salt linear gradient from $0 \%$ to $100 \%$ IEX buffer B (35 mM Tris-HCl $\mathrm{pH}$ 8, $1 \mathrm{M} \mathrm{NaCl}, 10 \%$ glycerol, $2 \mathrm{mM}$ TCEP) in $30 \mathrm{CV}$. Eluted fractions were analyzed by SDS PAGE and fractions containing BTK were pooled and subjected to size exclusion chromatography (SEC) in a running buffer containing $35 \mathrm{mM}$ Tris-HCL pH 8, $300 \mathrm{mM} \mathrm{NaCl}, 10 \%$ glycerol and 2 mM TCEP. The correct mass of the protein was confirmed by LC-MS and protein was frozen and stored at $-80^{\circ} \mathrm{C}$ in aliquots.

For crystallization, a solution containing $0.3 \mathrm{mM}$ of purified BTK in $20 \mathrm{mM}$ Tris-HCl pH 8.0, 100 $\mathrm{mM} \mathrm{NaCl}, 3 \mathrm{mM}$ TCEP, $1 \mathrm{mM}$ EDTA was mixed with LOU064 (25 mM in in $90 \%$ (v/v) deuterated DMSO) to reach a final compound concentration of $0.5 \mathrm{mM}$. Equal volumes ( $0.2 \mu \mathrm{l})$ of protein and a reservoir solution (3.5 M sodium formate) were mixed and the drop was incubated at room temperature in sitting drop SD2 plates (Molecular Dimensions) over $80 \mu \mathrm{l}$ reservoir solution. Single crystals were harvested and flash cooled in liquid nitrogen prior to diffraction data collection.

X-ray diffraction data were collected at beamline X10SA of the Swiss Light Source (Paul Scherrer Insitute, Villigen Switzerland) at $100 \mathrm{~K}$ using a PILATUS 6M pixel detector. Diffraction images were processed with XDS and intensities were scaled with XSCALE ${ }^{4}$. The structure of the complex of BTK and LOU064 was solved by molecular replacement with PHASER ${ }^{5}$ using coordinates of a BTK structure that was previously determined in-house (unpublished). Model building and refinement were carried out with $\mathrm{COOT}^{6}$ and BUSTER ${ }^{7}$. Data collection and 
refinement statistics are summarized in table S1. Coordinates of the refined structure were deposited in the PDB with accession number 6TFP.

Table S-1. Data collection and refinement statistics. Statistics for the highest-resolution shell are shown in parentheses.

\begin{tabular}{|l|l|}
\cline { 2 - 2 } \multicolumn{1}{c|}{} & BTK in complex with LOU064 \\
\hline Wavelength $(\AA)$ & 1.0000 \\
\hline Resolution range $(\AA)$ & $48-2.0(2.05-2.00)$ \\
\hline Space group & C2 \\
\hline Unit cell & $206.8 \AA \times 86.5 \AA \times 160.7 \AA$ \\
& $90^{\circ} \times 129.845^{\circ} \times 90^{\circ}$ \\
\hline Total reflections & $500909(36262)$ \\
\hline Unique reflections & $144269(10368)$ \\
\hline Multiplicity & $3.47(3.49)$ \\
\hline Completeness (\%) & $98.2(95.9)$ \\
\hline Mean I/sigma(I) & $20.74(1.96)$ \\
\hline Wilson B-factor $\left(\AA^{2}\right)$ & 39.8 \\
\hline No. of protein molecules / AU & 5 \\
\hline R-Factor (\%) & $3.4(59.8)$ \\
\hline R-meas (\%) & $4.0(70.5)$ \\
\hline CC1/2 & $100(78.8)$ \\
\hline Reflections used in refinement & \\
\hline
\end{tabular}




\begin{tabular}{|l|l|}
\hline Reflections used for R-free & 7214 (519) \\
\hline R-work (\%) & $18.6(24.9)$ \\
\hline R-free (\%) & $20.4(27.6)$ \\
\hline CC(work) & 0.956 \\
\hline CC(free) & 0.947 \\
\hline Number of non-hydrogen atoms & 11545 \\
\hline macromolecules & 10705 \\
\hline heterogen & 187 \\
\hline solvent & 653 \\
\hline Protein residues & 1335 \\
\hline RMS bond length ( $\AA$ ) & 0.010 \\
\hline RMS bond angles $(\AA)$ & 1.00 \\
\hline Ramachandran favored (\%) & 97 \\
\hline Ramachandran allowed (\%) & 3 \\
\hline Ramachandran outliers (\%) & 0 \\
\hline Rotamer outliers (\%) & 58.0 \\
\hline Average B-factor ( $\left.\AA^{2}\right)$ & \\
\hline Number of TLS groups & \\
\hline
\end{tabular}


Figure S-1. X-ray complex structure of BTK kinase domain bound to LOU064 (PDB 6TFP, protein chain A with ligand chain L). H-bonds of the 6-aminopyrimidine scaffold (in orange) to Met477 are highlighted (black dashed lines), as well as the multipolar contact of the fluorine with the carbonyl of Gly409 (shown in yellow). ${ }^{3}$ The H3 pocket of BTK, characteristic of its inactive state, is shown in green. For improved clarity water molecules are omitted.

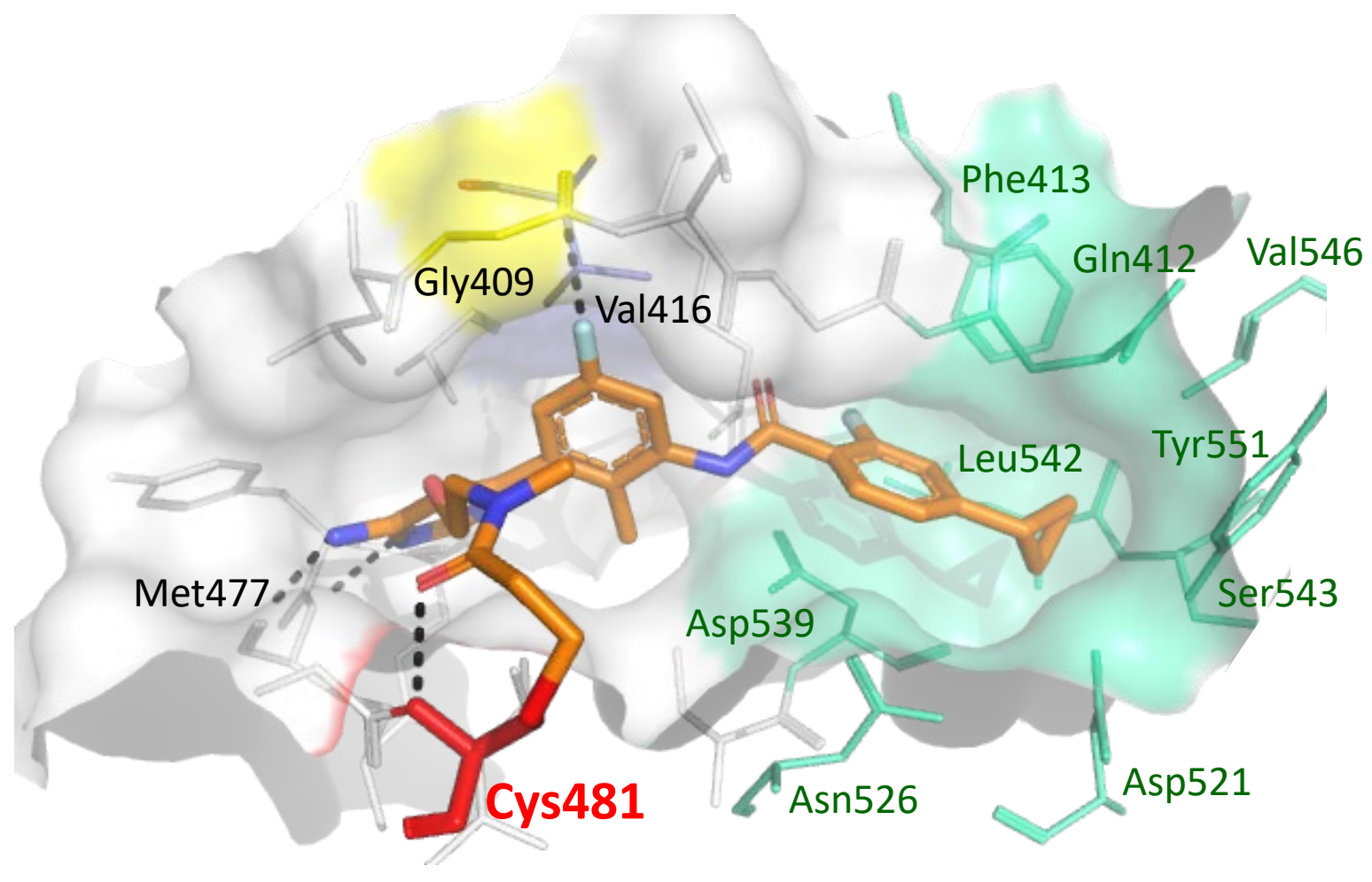




\section{Analysis of BTK/LOU064 complex by LC/MS}

A solution containing 0.030 mM BTK kinase domain, encompassing amino acids 386-659, and 0.036 mM LOU064 (1.2 times molar excess) was incubated for 10 minutes at room temperature, followed by LC-MS analysis. Positive-ion electrospray ionization (ESI) mass spectra were recorded (ACQUITY UPLC Protein BEH C4 2.1 x 100mm Column, $1.7 \mu \mathrm{m}$ /Xevo G2-S QTof MS, Waters). In comparison to unmodified BTK (31714.5 Da), a single adduct peak with the corresponding mass of 32222.3 Da was obtained. For the LC, the column temperature was set to $80^{\circ} \mathrm{C}$ and the following eluents were used. Buffer A: water $+0.05 \%$ TFA, buffer B: acetonitrile + 0.04\% TFA, gradient: initial 5\% B; from $5 \%$ to $60 \%$ B in 8.0 min; from $60 \%$ B to 98 \% B in 0.2 \% B; 2.1 min 98 \% B with a flow rate of $0.5 \mathrm{~mL} / \mathrm{min}$. Injection Mode: Partial loop. In brief, the following MS method was chosen: Time: 0 - 9.8 min, mass Range: 700 - 3000 m/z, ionization mode: ES+, data collection in continuum mode with a scan time of 0.1 sec. 
Table S-2. In vitro ADME profile of LOU064 (25)

assay

CYP 3A4, 2C9, 2D6 inhibition

CYP 3A induction: PXR reporter gene assay
Result

$5.0,14.1,>20 \mu \mathrm{M}$

$\mathrm{EC}_{50}>5.48 \mu \mathrm{M}, \mathrm{E}_{\max } 94.7 \%$ 


\section{BIOLOGY}

\section{Biochemical BTK Enzyme Assay}

The inhibitory activity of the present compounds against BTK was assessed in a biochemical enzyme assay. Assay plates in 384 well format were prepared with 8-point serial dilutions for the test compounds on a Thermo CatX workstation equipped with a Innovadyne Nanodrop Express. The assay plates were prepared by addition of $50 \mathrm{nl}$ per well of compound solution in $90 \%$ DMSO. The kinase reactions were started by stepwise addition of $4.5 \mu \mathrm{l}$ per well of peptide/ATP-solution (4 $\mu \mathrm{M}$ FITC-Ahx-TSELKKVVALYDYMPMNAND-NH2, $164 \mu \mathrm{M}$ ATP) in kinase buffer (50mM HEPES, pH 7.5, 1mM DTT, 0.02 \% Tween20, 0.02 \% BSA, 0.6 \% DMSO, 10 mM betaglycerophosphate, and $10 \mu \mathrm{M}$ sodium orthovanadate, $18 \mathrm{mM} \mathrm{MgCl}_{2}, 1 \mathrm{mM} \mathrm{MnCl}_{2}$ ) and $4.5 \mu \mathrm{l}$ per well of enzyme solution (6.4 nM full-length human recombinant BTK) in kinase buffer. Kinase reactions were incubated at $30^{\circ} \mathrm{C}$ for $60 \mathrm{~min}$ and subsequently terminated by addition of $16 \mu \mathrm{l}$ per well of stop solution (100 mM HEPES pH 7.5, 5 \% DMSO, 0.1 \% Caliper coating reagent, 10 mM EDTA, and 0.015 \% Brij35). Kinase reactions were analyzed on a Caliper LC3000 workstation by separating phosphorylated and unphosphorylated peptides and kinase activities were calculated from the amounts of newly formed phospho-peptide. Similar methods were used to profile the compounds against a panel of kinases, using specific substrate and ATP conditions. In all enzymatic assays, ATP was used at a concentration close to its $K_{m}$ in the same assay format.

For kinetic and dilution biochemical BTK assays, a substrate peptide of the same sequence with an aminoterminal biotin was used. Peptide phosphorylation was assessed by HTRF with antiphosphotyrosine (PT66) and SAXLent (Cisbio Bioassays). 


\section{Inhibition of FcyR-signaling in Human Monocytic THP1 Cells}

The effects of LOU064 on signaling from the activating Fc $\gamma \mathrm{R}$ were assessed in the human monocytic cell line THP1 (ATCC, TIB-202). The THP1 cell line expresses the two activating Fc $\gamma$ Rs CD32a (Fc $\gamma$ RII2) and CD64 (Fc $\gamma$ RI) that signal through BTK. ${ }^{8-10}$ Briefly, 384 well culture plates were coated with pooled non-specific human IgG fraction (Redimune, CSL Behring). Serial compound dilutions were dispensed into the IgG-coated plates containing a small volume of tissue culture medium. Then THP1 cells that were pre-differentiated by vitamin D3 treatment for 5 days were added to each well. ${ }^{9}$ Twenty-four hours later the secretion of IL-8 in the supernatant of these culture wells was assessed by a homogenous immunoassay (HTRF, Cisbio Bioassays).

\section{In vitro BTK Binding in Human Blood}

Blood from healthy volunteers was provided under informed consent and collected through the Novartis Tissue Donor Program in accordance with the Swiss Human Research Act and approval of the responsible ethic committee.

Serial compound dilutions were mixed into fresh human heparinized blood and incubated at room temperature to allow binding of the compounds to cellular BTK. At given time points, aliquots were sampled and added to a lysis buffer containing excess biotinylated probe. ${ }^{11}$ The lysates were analyzed for covalent binding of compounds to BTK with immunoassays for free BTK protein (i.e. not covalently occupied by compound) and total BTK protein using the MSD (Meso Scale Discovery) platform. For free BTK measurements, a streptavidin-coated MSD assay plate was incubated with the biotinylated covalent BTK probe, then samples were added to allow binding of the unoccupied free BTK to the plate-bound probe. The binding of the probe to BTK is mutually exclusive with compound binding to BTK. Plate-bound BTK was detected with a 
SULFO TAG-labelled anti-BTK antibody (D3H5, Cell Signaling Technology). For total BTK measurements, an MSD assay plate was coated with D3H5 anti-BTK to capture total BTK (free BTK and BTK bound to compounds). A SULFO TAG-labelled anti-BTK antibody (\#53, BD Biosciences) was then used to detect captured BTK. The signals from both assays were calibrated against standard curves generated with recombinant BTK protein. The respective free BTK levels for each sample were normalized to the total BTK level in the same sample and these ratios were expressed as percentage of the vehicle control samples.

\section{Human Blood B cell and Basophil Inhibition Assays}

The effects of the inhibitors were assessed in human primary B cells and basophils in blood. Blood from healthy volunteers was provided under informed consent and collected through the Novartis Tissue Donor Program in accordance with the Swiss Human Research Act and approval of the responsible ethics committee.

For B cell inhibition, fresh human heparinized blood diluted to $90 \%$ was preincubated with compound for 1 hour at $37^{\circ} \mathrm{C}$. Then stimulated with a polyclonal anti-IgM antibody ( $30 \mu \mathrm{g} / \mathrm{ml}$, Southern Biotech) in the presence of non-activating levels of recombinant human IL-4 (5 ng/ml, Immunotools). Activation of B cells was measured by flow cytometry 16 hours later after red blood cell lysis and by reading cell surface expression of the activation markers CD69 (FN50 BD Biosciences) on CD19 positive (HIB19 BD Biosciences) B cells.

For basophil inhibition, fresh human heparinized blood diluted to $90 \%$ was preincubated with compound and the human IgE antibody B11 for 30 minutes at $37^{\circ} \mathrm{C}$, then stimulated with the antiIgE mouse IgG1 antibody Le27. Activation of basophils was measured by flow cytometry 15 min later by reading cell surface expression of the activation markers CD63 on IgE+ cells. 
Figure S-2. TREEspot ${ }^{\mathrm{TM}}$ Kinase Dendrogram of LOU064. Dot size indicates extent of LOU064 kinase binding (percent remaining probe binding vs control). Small green dots indicate inhibition below assay-relevant $35 \%$ threshold. BTK is marked in red and TEC in blue. Image generated using TREEspot ${ }^{\mathrm{TM}}$ Software Tool and reprinted with permission from KINOMEscan ${ }^{\circledR}$, a division of DiscoveRx Corporation, (C) DISCOVERX CORPORATION 2010.

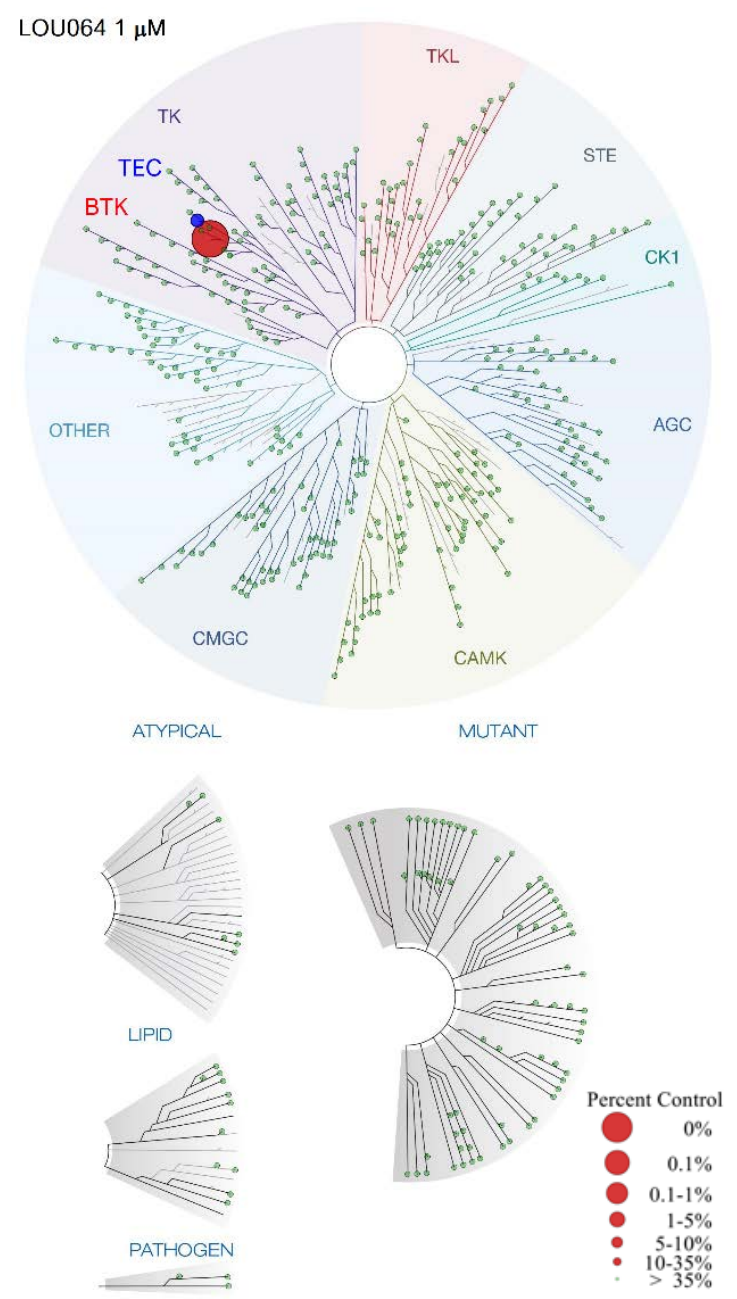


KINOMEscan data

All kinases tested at $1 \mu \mathrm{M}$ LOU064 


\begin{tabular}{|c|c|c|c|c|c|c|c|}
\hline $\begin{array}{l}\text { DiscoveRx Gene } \\
\text { Symbol }\end{array}$ & $\begin{array}{l}\text { Percent } \\
\text { Control }\end{array}$ & $\begin{array}{l}\text { DiscoveRx Gene } \\
\text { Symbol }\end{array}$ & $\begin{array}{l}\text { Percent } \\
\text { Control }\end{array}$ & $\begin{array}{l}\text { DiscoveRx Gene } \\
\text { Symbol }\end{array}$ & \begin{tabular}{|l|} 
Percent \\
Control
\end{tabular} & $\begin{array}{l}\text { DiscoveRx Gene } \\
\text { Symbol }\end{array}$ & $\begin{array}{l}\text { Percent } \\
\text { Control }\end{array}$ \\
\hline AAK1 & 86 & EGFR & 82 & MAP3K4 & 99 & PRKCD & 94 \\
\hline \begin{tabular}{|l} 
ABL1(E255K)- \\
phosphorylated
\end{tabular} & 88 & $\begin{array}{l}\text { EGFR(E746- } \\
\text { A750del) }\end{array}$ & 86 & MAP4K2 & 84 & PRKCE & 96 \\
\hline $\begin{array}{l}\text { ABL1(F317I)- } \\
\text { nonphosphorylated }\end{array}$ & 95 & EGFR(G719C) & 94 & MAP4K3 & 99 & PRKCH & 83 \\
\hline $\begin{array}{l}\text { ABL1(F317I)- } \\
\text { phosphorylated }\end{array}$ & 83 & EGFR(G719S) & 92 & MAP4K4 & 95 & PRKCl & 100 \\
\hline $\begin{array}{l}\text { ABL1(F317L)- } \\
\text { nonphosphorylated }\end{array}$ & 93 & $\begin{array}{l}\text { EGFR(L747- } \\
\text { E749del, A750P) }\end{array}$ & 94 & MAP4K5 & 100 & PRKCQ & 100 \\
\hline \begin{tabular}{|l} 
ABL1(F317L)- \\
phosphorylated
\end{tabular} & 99 & $\begin{array}{l}\text { EGFR(L747- } \\
\text { S752del, P753S) }\end{array}$ & 87 & MAPKAPK2 & 93 & PRKD1 & 97 \\
\hline $\begin{array}{l}\text { ABL1(H396P)- } \\
\text { nonphosphorylated }\end{array}$ & 87 & $\begin{array}{l}\text { EGFR(L747- } \\
\text { T751del,Sins) }\end{array}$ & 92 & MAPKAPK5 & 98 & PRKD2 & 100 \\
\hline $\begin{array}{l}\text { ABL1(H396P)- } \\
\text { phosphorylated }\end{array}$ & 83 & EGFR(L858R) & 88 & MARK1 & 92 & PRKD3 & 90 \\
\hline $\begin{array}{l}\text { ABL1(M351T)- } \\
\text { phosphorylated }\end{array}$ & 91 & $\begin{array}{l}\text { EGFR(L858R,T790 } \\
\text { M) }\end{array}$ & 100 & MARK2 & 92 & PRKG1 & 100 \\
\hline $\begin{array}{l}\text { ABL1(Q252H)- } \\
\text { nonphosphorylated }\end{array}$ & 100 & EGFR(L861Q) & 83 & MARK3 & 88 & PRKG2 & 100 \\
\hline $\begin{array}{l}\text { ABL1(Q252H)- } \\
\text { phosphorylated }\end{array}$ & 84 & $\begin{array}{l}\text { EGFR(S752- } \\
\text { 1759del) }\end{array}$ & 100 & MARK4 & 84 & PRKR & 88 \\
\hline $\begin{array}{l}\text { ABL1(T315I)- } \\
\text { nonphosphorylated }\end{array}$ & 100 & EGFR(T790M) & 100 & MAST1 & 88 & PRKX & 100 \\
\hline \begin{tabular}{|l|} 
ABL1(T315I)- \\
phosphorylated
\end{tabular} & 100 & EIF2AK1 & 100 & MEK1 & 100 & PRP4 & 100 \\
\hline $\begin{array}{l}\text { ABL1(Y253F)- } \\
\text { phosphorylated }\end{array}$ & 100 & EPHA1 & 91 & MEK2 & 100 & PYK2 & 100 \\
\hline $\begin{array}{l}\text { ABL1- } \\
\text { nonphosphorylated }\end{array}$ & 88 & EPHA2 & 99 & MEK3 & 100 & QSK & 100 \\
\hline $\begin{array}{l}\text { ABL1- } \\
\text { phosphorylated }\end{array}$ & 78 & EPHA3 & 100 & MEK4 & 99 & RAF1 & 100 \\
\hline ABL2 & 94 & EPHA4 & 78 & MEK5 & 100 & RET & 96 \\
\hline ACVR1 & 100 & EPHA5 & 100 & MEK6 & 83 & RET(M918T) & 84 \\
\hline ACVR1B & 98 & EPHA6 & 87 & MELK & 90 & RET(V804L) & 82 \\
\hline ACVR2A & 100 & EPHA7 & 95 & MERTK & 49 & RET(V804M) & 100 \\
\hline ACVR2B & 100 & EPHA8 & 78 & MET & 98 & RIOK1 & 62 \\
\hline ACVRL1 & 91 & EPHB1 & 98 & MET(M1250T) & 92 & RIOK2 & 100 \\
\hline ADCK3 & 76 & EPHB2 & 100 & MET(Y1235D) & 95 & RIOK3 & 51 \\
\hline ADCK4 & 100 & EPHB3 & 79 & MINK & 86 & RIPK1 & 76 \\
\hline AKT1 & 93 & EPHB4 & 91 & MKK7 & 75 & RIPK2 & 100 \\
\hline AKT2 & 100 & EPHB6 & 100 & MKNK1 & 95 & RIPK4 & 100 \\
\hline AKT3 & 100 & ERBB2 & 80 & MKNK2 & 86 & RIPK5 & 100 \\
\hline ALK & 100 & ERBB3 & 99 & MLCK & 100 & ROCK1 & 100 \\
\hline ALK(C1156Y) & 98 & ERBB4 & 100 & MLK1 & 89 & ROCK2 & 100 \\
\hline ALK(L1196M) & 89 & ERK1 & 94 & MLK2 & 100 & ROS1 & 93 \\
\hline AMPK-alpha1 & 100 & ERK2 & 100 & MLK3 & 92 & $\begin{array}{l}\text { RPS6KA4(Kin.Dom. } \\
\text { 1-N-terminal) }\end{array}$ & 100 \\
\hline AMPK-alpha2 & 72 & ERK3 & 67 & MRCKA & 100 & $\begin{array}{l}\text { RPS6KA4(Kin.Dom. } \\
\text { 2-C-terminal) }\end{array}$ & 100 \\
\hline ANKK1 & 92 & ERK4 & 62 & MRCKB & 100 & $\begin{array}{l}\text { RPS6KA5(Kin.Dom. } \\
\text { 1-N-terminal) }\end{array}$ & 81 \\
\hline ARK5 & 92 & ERK5 & 92 & MST1 & 100 & $\begin{array}{l}\text { RPS6KA5(Kin.Dom. } \\
\text { 2-C-terminal) }\end{array}$ & 98 \\
\hline ASK1 & 100 & ERK8 & 100 & MST1R & 100 & $\begin{array}{l}\text { RSK1(Kin.Dom.1-N- } \\
\text { terminal) }\end{array}$ & 84 \\
\hline ASK2 & 100 & ERN1 & 100 & MST2 & 84 & $\begin{array}{l}\text { RSK1(Kin.Dom.2-C- } \\
\text { terminal) }\end{array}$ & 96 \\
\hline AURKA & 99 & FAK & 100 & MST3 & 99 & $\begin{array}{l}\text { RSK2(Kin.Dom.1-N- } \\
\text { terminal) }\end{array}$ & 99 \\
\hline
\end{tabular}




\begin{tabular}{|c|c|c|c|c|c|c|c|}
\hline AURKB & 92 & FER & 97 & MST4 & 100 & $\begin{array}{l}\text { RSK2(Kin.Dom.2-C- } \\
\text { terminal) }\end{array}$ & -98 \\
\hline AURKC & 52 & FES & 90 & MTOR & 94 & $\begin{array}{l}\text { RSK3(Kin.Dom.1-N- } \\
\text { terminal) }\end{array}$ & -100 \\
\hline $\mathrm{AXL}$ & 100 & FGFR1 & 89 & MUSK & 93 & $\begin{array}{l}\text { RSK3(Kin.Dom.2-C- } \\
\text { terminal) }\end{array}$ & -100 \\
\hline BIKE & 77 & FGFR2 & 100 & MYLK & 98 & $\begin{array}{l}\text { RSK4(Kin.Dom.1-N- } \\
\text { terminal) }\end{array}$ & -100 \\
\hline BLK & 100 & FGFR3 & 100 & MYLK2 & 100 & $\begin{array}{l}\text { RSK4(Kin.Dom.2-C- } \\
\text { terminal) }\end{array}$ & -96 \\
\hline BMPR1A & 100 & FGFR3(G697C) & 83 & MYLK4 & 87 & S6K1 & 98 \\
\hline BMPR1B & 100 & FGFR4 & 96 & MYO3A & 98 & SBK1 & 78 \\
\hline BMPR2 & 100 & FGR & 83 & MYO3B & 94 & SGK & 71 \\
\hline BMX & 53 & FLT1 & 80 & NDR1 & 92 & SgK110 & 95 \\
\hline BRAF & 100 & FLT3 & 100 & NDR2 & 99 & SGK2 & 83 \\
\hline BRAF(V600E) & 95 & FLT3(D835H) & 98 & NEK1 & 79 & SGK3 & 100 \\
\hline BRK & 100 & FLT3(D835Y) & 99 & NEK10 & 100 & SIK & 100 \\
\hline BRSK1 & 97 & FLT3(ITD) & 63 & NEK11 & 83 & SIK2 & 100 \\
\hline BRSK2 & 100 & FLT3(K663Q) & 97 & NEK2 & 97 & SLK & 100 \\
\hline BTK & 0.25 & FLT3(N841I) & 92 & NEK3 & 92 & SNARK & 100 \\
\hline BUB1 & 94 & FLT3(R834Q) & 84 & NEK4 & 87 & SNRK & 100 \\
\hline CAMK1 & 91 & FLT3-autoinhibited & 99 & NEK5 & 84 & SRC & 99 \\
\hline CAMK1D & 96 & FLT4 & 98 & NEK6 & 100 & SRMS & 94 \\
\hline CAMK1G & 93 & FRK & 100 & NEK7 & 100 & SRPK1 & 84 \\
\hline CAMK2A & 100 & FYN & 100 & NEK9 & 100 & SRPK2 & 97 \\
\hline CAMK2B & 100 & GAK & 99 & NIK & 92 & SRPK3 & 91 \\
\hline CAMK2D & 86 & $\begin{array}{l}\text { GCN2(Kin.Dom.2,S } \\
\text { 808G) }\end{array}$ & 100 & NIM1 & 85 & STK16 & 98 \\
\hline CAMK2G & 86 & GRK1 & 100 & NLK & 99 & STK33 & 89 \\
\hline CAMK4 & 85 & GRK4 & 100 & OSR1 & 88 & STK35 & 100 \\
\hline CAMKK1 & 88 & GRK7 & 95 & p38-alpha & 98 & STK36 & 93 \\
\hline CAMKK2 & 80 & GSK3A & 97 & p38-beta & 100 & STK39 & 95 \\
\hline CASK & 88 & GSK3B & 100 & p38-delta & 100 & SYK & 94 \\
\hline CDC2L1 & 100 & HASPIN & 93 & p38-gamma & 98 & TAK1 & 96 \\
\hline CDC2L2 & 94 & HCK & 96 & PAK1 & 83 & TAOK1 & 86 \\
\hline CDC2L5 & 88 & HIPK1 & 94 & PAK2 & 82 & TAOK2 & 96 \\
\hline CDK11 & 67 & HIPK2 & 100 & PAK3 & 100 & TAOK3 & 95 \\
\hline CDK2 & 100 & HIPK3 & 92 & PAK4 & 90 & TBK1 & 89 \\
\hline CDK3 & 91 & HIPK4 & 100 & PAK6 & 100 & TEC & 24 \\
\hline CDK4-cyclinD1 & 100 & HPK1 & 100 & PAK7 & 95 & TESK1 & 80 \\
\hline CDK4-cyclinD3 & 95 & HUNK & 88 & PCTK1 & 98 & TGFBR1 & 100 \\
\hline CDK5 & 97 & ICK & 100 & PCTK2 & 91 & TGFBR2 & 100 \\
\hline CDK7 & 97 & IGF1R & 88 & PCTK3 & 87 & TIE1 & 83 \\
\hline CDK8 & 100 & IKK-alpha & 100 & PDGFRA & 89 & TIE2 & 100 \\
\hline CDK9 & 97 & IIKK-beta & 98 & PDGFRB & 91 & TLK1 & 85 \\
\hline CDKL1 & 98 & IKK-epsilon & 99 & PDPK1 & 95 & TLK2 & 93 \\
\hline CDKL2 & 96 & INSR & 90 & $\begin{array}{l}\text { PFCDPK1(P.falcip } \\
\text { arum) }\end{array}$ & 60 & TNIK & 100 \\
\hline CDKL3 & 77 & INSRR & 97 & $\begin{array}{l}\text { PFPK5(P.falciparu } \\
\text { m) }\end{array}$ & 100 & TNK1 & 92 \\
\hline CDKL5 & 94 & \begin{tabular}{|l|} 
IRAK1 \\
\end{tabular} & 87 & PFTAIRE2 & 100 & TNK2 & 100 \\
\hline CHEK1 & 88 & IRAK3 & 100 & PFTK1 & 96 & TNNI3K & 100 \\
\hline CHEK2 & 75 & \begin{tabular}{|l|l|} 
IRAK4 \\
\end{tabular} & 95 & PHKG1 & 100 & TRKA & 87 \\
\hline
\end{tabular}




\begin{tabular}{|c|c|c|c|c|c|c|c|}
\hline CIT & 50 & ITK & 88 & PHKG2 & 100 & TRKB & 69 \\
\hline CLK1 & 70 & $\begin{array}{l}\text { JAK1(JH1domain- } \\
\text { catalytic) }\end{array}$ & 69 & PIK3C2B & 100 & TRKC & 74 \\
\hline CLK2 & 100 & $\begin{array}{l}\text { JAK1(JH2domain- } \\
\text { pseudokinase) }\end{array}$ & 100 & PIK3C2G & 100 & TRPM6 & 61 \\
\hline CLK3 & 90 & $\begin{array}{l}\text { JAK2(JH1domain- } \\
\text { catalytic) }\end{array}$ & 93 & PIK3CA & 89 & TSSK1B & 100 \\
\hline CLK4 & 81 & $\begin{array}{l}\text { JAK3(JH1domain- } \\
\text { catalytic) }\end{array}$ & 49 & PIK3CA(C420R) & 92 & TTK & 100 \\
\hline CSF1R & 98 & JNK1 & 85 & PIK3CA(E542K) & 100 & TXK & 90 \\
\hline \begin{tabular}{|l|} 
CSF1R- \\
autoinhibited
\end{tabular} & 64 & JNK2 & 90 & PIK3CA(E545A) & 88 & $\begin{array}{l}\text { TYK2(JH1domain- } \\
\text { catalytic) }\end{array}$ & 100 \\
\hline CSK & 93 & JNK3 & 83 & PIK3CA(E545K) & 100 & $\begin{array}{l}\text { TYK2(JH2domain- } \\
\text { pseudokinase) }\end{array}$ & 91 \\
\hline CSNK1A1 & 99 & KIT & 96 & PIK3CA(H1047L) & 100 & TYRO3 & 100 \\
\hline CSNK1A1L & 100 & KIT(A829P) & 82 & PIK3CA(H1047Y) & 100 & ULK1 & 85 \\
\hline CSNK1D & 100 & KIT(D816H) & 92 & PIK3CA(I800L) & 95 & ULK2 & 98 \\
\hline CSNK1E & 97 & KIT(D816V) & 91 & PIK3CA(M1043I) & 72 & ULK3 & 100 \\
\hline CSNK1G1 & 99 & KIT(L576P) & 96 & PIK3CA(Q546K) & 100 & VEGFR2 & 90 \\
\hline CSNK1G2 & 93 & KIT(V559D) & 98 & PIK3CB & 100 & VRK2 & 94 \\
\hline CSNK1G3 & 91 & KIT(V559D,T670I) & 95 & PIK3CD & 78 & WEE1 & 100 \\
\hline CSNK2A1 & 92 & KIT(V559D,V654A) & 100 & PIK3CG & 100 & WEE2 & 93 \\
\hline CSNK2A2 & 59 & KIT-autoinhibited & 99 & PIK4CB & 84 & WNK1 & 80 \\
\hline CTK & 89 & LATS1 & 92 & PIM1 & 90 & WNK3 & 77 \\
\hline DAPK1 & 94 & LATS2 & 99 & PIM2 & 89 & YANK1 & 88 \\
\hline DAPK2 & 100 & LCK & 98 & PIM3 & 86 & YANK2 & 80 \\
\hline DAPK3 & 99 & LIMK1 & 94 & PIP5K1A & 70 & YANK3 & 100 \\
\hline DCAMKL1 & 93 & LIMK2 & 65 & PIP5K1C & 100 & YES & 88 \\
\hline DCAMKL2 & 97 & LKB1 & 87 & PIP5K2B & 88 & YSK1 & 88 \\
\hline DCAMKL3 & 50 & LOK & 100 & PIP5K2C & 83 & YSK4 & 94 \\
\hline DDR1 & 89 & LRRK2 & 100 & PKAC-alpha & 100 & ZAK & 88 \\
\hline DDR2 & 94 & LRRK2(G2019S) & 100 & PKAC-beta & 92 & ZAP70 & 96 \\
\hline DLK & 100 & LTK & 100 & PKMYT1 & 96 & & \\
\hline DMPK & 100 & LYN & 100 & PKN1 & 100 & & \\
\hline DMPK2 & 77 & LZK & 100 & PKN2 & 87 & & \\
\hline DRAK1 & 100 & MAK & 100 & $\begin{array}{l}\text { PKNB(M.tuberculo } \\
\text { sis) }\end{array}$ & 92 & & \\
\hline DRAK2 & 100 & MAP3K1 & 100 & PLK1 & 75 & & \\
\hline DYRK1A & 93 & MAP3K15 & 100 & PLK2 & 87 & & \\
\hline DYRK1B & 69 & MAP3K2 & 98 & PLK3 & 90 & & \\
\hline DYRK2 & 89 & MAP3K3 & 95 & PLK4 & 75 & & \\
\hline
\end{tabular}




\section{BioMap profiling data}

\begin{tabular}{|c|c|c|c|c|}
\hline LOU064 & $10000 \mathrm{nM}$ & $3000 \mathrm{nM}$ & $900 \mathrm{nM}$ & $270 \mathrm{nM}$ \\
\hline 3C:CCL2/MCP-1 & -0.06311433 & -0.021976585 & -0.017289808 & -0.02280894 \\
\hline 3C:CD106/VCAM-1 & -0.03300329 & -0.008762175 & -0.008135996 & 0.0137511 \\
\hline 3C:CD141/Thrombomodulin & -0.055100683 & -0.016692849 & -0.015333555 & 0.004561274 \\
\hline 3C:CD142/Tissue Factor & -0.000591472 & 0.009332481 & -0.013665512 & -0.021146744 \\
\hline 3C:CD54/ICAM-1 & -0.001997261 & 0.015376122 & -0.004113461 & 0.01739967 \\
\hline 3C:CD62E/E-Selectin & 0.016096875 & 0.034416772 & 0.022611976 & 0.009559148 \\
\hline 3C:CD87/UPAR & -0.009486348 & -0.000953362 & 0.04167771 & -0.024377905 \\
\hline 3C:CXCL8/L-8 & 0.050365634 & 0.020367831 & 0.032956958 & 0.053320646 \\
\hline 3C:CXCL9/MIG & -0.013264285 & -0.010173207 & -0.022442654 & -0.012032665 \\
\hline 3C:HLA-DR & 0.011726409 & 0.000179874 & 0.012845726 & -0.012372582 \\
\hline 3C:Proliferation & 0.061730515 & 0.08114356 & 0.09515427 & 0.08114356 \\
\hline 3C:SRB & -0.026028927 & -0.021877382 & 5.4563E-05 & 0.017171832 \\
\hline $4 \mathrm{H}: \mathrm{CCL} 2 / \mathrm{MCP}-1$ & 0.04943384 & 0.018626323 & 0.04914217 & 0.057092533 \\
\hline 4H:CCL26/Eotaxin-3 & -0.054949902 & -0.051347166 & -0.020744724 & -0.005689814 \\
\hline 4H:CD106/VCAM-1 & 0.0328317 & 0.022903517 & 0.024344362 & 0.021276832 \\
\hline $4 \mathrm{H}: \mathrm{CD} 62 \mathrm{P} / \mathrm{P}$-selectin & 0.068636954 & 0.094706014 & 0.20358083 & 0.124507464 \\
\hline $4 \mathrm{H}:$ CD87/uPAR & 0.02674592 & 0.043091975 & 0.05864277 & -0.008152301 \\
\hline $4 \mathrm{H}: \mathrm{SRB}$ & -0.016791645 & 0.008543175 & -0.00023075 & 0.008543175 \\
\hline 4H:VEGFR2 & -0.032449394 & -0.023431977 & -0.012208179 & -0.011122442 \\
\hline LPS:CCL2/MCP-1 & -0.023346134 & -0.004015565 & 0.02345691 & 0.035733774 \\
\hline LPS:CD106/VCAM-1 & -0.07357592 & -0.030362353 & -0.03546867 & -0.016173951 \\
\hline LPS:CD141/Thrombomodulin & -0.008308702 & -0.009268469 & -0.01119439 & 0.003979012 \\
\hline LPS:CD142/Tissue Factor & -0.006928609 & -0.004059386 & 0.021067401 & -0.034896273 \\
\hline LPS:CD40 & -0.071097866 & -0.05414127 & -0.07874669 & -0.10641456 \\
\hline LPS:CD62E/E-Selectin & -0.008036527 & -0.011414644 & -0.019699248 & -0.003737365 \\
\hline LPS:CD69 & -0.075494416 & 0.008398254 & -0.031422798 & -0.0297824 \\
\hline LPS:CXCL8/IL-8 & -0.024637286 & -0.019581253 & -0.005356363 & 0.031364642 \\
\hline LPS:IL-1alpha & 0.038327795 & 0.001898527 & -0.018240236 & -0.013761719 \\
\hline LPS:M-CSF & -0.094187155 & -0.031796474 & -0.032203786 & -0.007453784 \\
\hline LPS:SPGE2 & 0.06924811 & 0.08238552 & 0.07451545 & 0.045509588 \\
\hline LPS:SRB & -0.014532735 & -0.000953865 & -0.001335998 & -0.001335998 \\
\hline LPS:sTNF-alpha & -0.12674809 & -0.084503 & -0.044590745 & -0.030692134 \\
\hline SAg:CCL2/MCP-1 & -0.037531093 & -0.0303421 & -0.00438374 & -0.015807973 \\
\hline SAg:CD38 & -0.007148396 & -0.008820425 & -0.018576324 & 0.003312927 \\
\hline SAg:CD40 & -0.05283502 & -0.01842093 & -0.010673814 & -0.008824344 \\
\hline SAg:CD62E/E-Selectin & -0.046066 & -0.006106195 & 0.012528199 & 0.01887039 \\
\hline SAg:CD69 & -0.06804416 & -0.04317638 & -0.046570793 & -0.04531051 \\
\hline SAg:CXCL8/IL-8 & 0.019139564 & 0.060493954 & 0.05918988 & 0.06324266 \\
\hline
\end{tabular}




\begin{tabular}{|c|c|c|c|c|}
\hline SAg:CXCL9/MIG & -0.025164206 & -0.027919307 & -0.002512633 & -0.003103913 \\
\hline SAg:PBMC Cytotoxicity & -0.05294592 & -0.04711387 & -0.028367965 & 0.04468471 \\
\hline SAg:Proliferation & -0.051779237 & -0.06917967 & -0.028029397 & 0.009928773 \\
\hline SAg:SRB & -0.021375332 & -0.016564181 & -0.0027989 & -0.001730524 \\
\hline BT:B cell Proliferation & -0.3200264 & -0.24142556 & -0.21342765 & -0.21973827 \\
\hline BT:PBMC Cytotoxicity & -0.16839188 & -0.15028745 & -0.13490231 & -0.12520196 \\
\hline BT:Secreted IgG & -0.69026124 & -0.71659017 & -0.75191814 & -0.78240746 \\
\hline BT:SIL-17A & -0.66451025 & -0.5661589 & -0.5527218 & -0.72433573 \\
\hline BT:SIL-17F & -0.056283053 & -0.06330684 & -0.039205056 & -0.091335565 \\
\hline BT:SIL-2 & -0.7445262 & -0.6669577 & -0.6411845 & -0.5984506 \\
\hline BT:SIL-6 & -0.7407526 & -0.5744137 & -0.60332745 & -0.7225076 \\
\hline BT:sTNF-alpha & -0.83014077 & -0.64906365 & -0.60322654 & -0.82544446 \\
\hline BF4T:CCL2/MCP-1 & -0.06472613 & -0.05567907 & -0.05654476 & -0.02546834 \\
\hline BF4T:CCL26/Eotaxin-3 & -0.042916715 & -0.029836884 & -0.017675163 & 0.041838367 \\
\hline BF4T:CD106/VCAM-1 & -0.03108495 & -0.011076096 & -0.015328887 & -0.002407255 \\
\hline BF4T:CD54//CAM-1 & 0.003833746 & -0.00129124 & -0.01211632 & 0.005097074 \\
\hline BF4T:CD90 & -0.013942481 & -0.009660983 & -0.018510038 & -0.017710712 \\
\hline BF4T:CXCL8/IL-8 & -0.037062254 & -0.018737735 & -0.0047439 & -0.02348198 \\
\hline BF4T:IL-1alpha & -0.013466817 & -0.011224215 & 0.023409668 & 0.02182739 \\
\hline BF4T:Keratin 8/18 & 0.020232162 & -0.0174387 & -0.014015904 & -0.001222664 \\
\hline BF4T:MMP-1 & 0.019732555 & 0.004975184 & -0.002943207 & 0.003608402 \\
\hline BF4T:MMP-3 & 0.00646163 & -0.018361954 & 0.004349299 & -0.003772587 \\
\hline BF4T:MMP-9 & 0.03498931 & 0.013254526 & 0.011979064 & 0.009416848 \\
\hline BF4T:PAI-I & 0.01332445 & $-1.24177 \mathrm{E}-05$ & 0.007407672 & 0.006070928 \\
\hline BF4T:SRB & -0.017340668 & -0.000109215 & -0.006565063 & -0.002445708 \\
\hline BF4T:tPA & -0.002366557 & 0.026798427 & -0.013428628 & 0.03530641 \\
\hline BF4T:UPA & 0.001797292 & -0.013308241 & -0.008626564 & -0.028044177 \\
\hline BE3C:CD54//CAM-1 & -0.021062478 & -0.010116638 & -0.025700724 & -0.007197759 \\
\hline BE3C:CD87/UPAR & 0.023528812 & 0.031284276 & 0.037242536 & 0.001408089 \\
\hline BE3C:CXCL10/IP-10 & 0.002797915 & 0.022190752 & 0.028612452 & 0.027978502 \\
\hline BE3C:CXCL11/I-TAC & -0.005574609 & -0.012124237 & -0.02262033 & -0.03271687 \\
\hline BE3C:CXCL8/IL-8 & -0.016695092 & 0.03389315 & 0.049235463 & 0.049235463 \\
\hline BE3C:CXCL9/MIG & -0.001044364 & -0.005433084 & -0.001755179 & 0.009326487 \\
\hline BE3C:EGFR & -0.003019441 & -0.008738105 & -0.026582371 & -0.03091352 \\
\hline BE3C:HLA-DR & -0.01418984 & $-1.68677 \mathrm{E}-05$ & -0.01843965 & -0.005767397 \\
\hline BE3C:IL-1alpha & -0.033964 & -0.030465735 & -0.0894969 & -0.07574665 \\
\hline BE3C:Keratin 8/18 & 0.017666535 & -0.002327017 & -0.003610925 & 0.00358115 \\
\hline BE3C:MMP-1 & 0.054316934 & 0.0386778 & 0.002465628 & -0.004673621 \\
\hline BE3C:MMP-9 & 0.024250798 & -0.005182475 & 0.01233439 & -0.017946882 \\
\hline BE3C:PAI-I & 0.02230056 & 0.010785383 & -0.009482556 & -0.03419355 \\
\hline BE3C:SRB & -0.003296606 & 0.004672323 & 0.002032227 & -0.001290623 \\
\hline
\end{tabular}




\begin{tabular}{|c|c|c|c|c|}
\hline BE3C:tPA & -0.041564256 & 0.018881435 & 0.036244027 & 0.002869865 \\
\hline BE3C:UPA & -0.007066629 & -0.012682303 & -0.027217498 & -0.0244063 \\
\hline CASM3C:CCL2/MCP-1 & 0.009717921 & 0.015238536 & 0.02363471 & 0.015345386 \\
\hline CASM3C:CD106/VCAM-1 & -0.038998533 & 0.036679547 & -0.040523715 & -0.06625147 \\
\hline CASM3C:CD141/Thrombomodulin & -0.06834268 & -0.059862457 & -0.06956777 & -0.07450298 \\
\hline CASM3C:CD142/Tissue Factor & -0.11890956 & -0.09352524 & -0.0880495 & -0.0749679 \\
\hline CASM3C:CD87/uPAR & -0.06022592 & -0.034752227 & -0.004657758 & -0.032276638 \\
\hline CASM3C:CXCL8/IL-8 & -0.019801144 & 0.013496545 & -0.047918275 & -0.007641586 \\
\hline CASM3C:CXCL9/MIG & 0.041357394 & 0.024781598 & -0.007018157 & -0.010482729 \\
\hline CASM3C:HLA-DR & -0.0406464 & -0.025617408 & -0.043155972 & -0.061724495 \\
\hline CASM3C:IL-6 & -0.042936314 & -0.0353409 & -0.0335376 & -0.051603917 \\
\hline CASM3C:LDLR & -0.16158938 & -0.07150953 & $\begin{array}{l}-0.11976632 \\
\end{array}$ & -0.095867455 \\
\hline CASM3C:M-CSF & -0.22481366 & -0.15916425 & -0.12904914 & -0.120736495 \\
\hline CASM3C:PAI-I & -0.003778304 & -0.006642582 & -0.004160819 & 0.006225033 \\
\hline CASM3C:Proliferation & -0.07463362 & -0.019021373 & 0.013163311 & 0.007307566 \\
\hline CASM3C:Serum Amyloid A & -0.10616474 & -0.015988106 & -0.021451002 & 0.120336026 \\
\hline CASM3C:SRB & -0.011788748 & -0.000562418 & 0.010043174 & 0.000475324 \\
\hline HDF3CGF:CCL2/MCP-1 & -0.026178274 & -0.018906198 & -0.000527734 & -0.007384576 \\
\hline HDF3CGF:CD106/VCAM-1 & -0.030947505 & -0.044487007 & -0.03791528 & -0.11140196 \\
\hline HDF3CGF:CD54/ICAM-1 & -0.00553672 & 0.004233263 & -0.007006636 & -0.006581482 \\
\hline HDF3CGF:Collagen I & -0.05296492 & -0.035608627 & 0.01750263 & -0.022290938 \\
\hline HDF3CGF:Collagen III & -0.014198029 & 0.025956178 & 0.004375869 & -0.029793343 \\
\hline HDF3CGF:CXCL10/IP-10 & 0.012826579 & 0.025036465 & 0.009528766 & 0.017501863 \\
\hline HDF3CGF:CXCL11/I-TAC & -0.022209842 & 0.012162066 & 0.028214816 & 0.019006813 \\
\hline HDF3CGF:CXCL8/IL-8 & 0.001801565 & 0.000586248 & -0.00162034 & 0.020896727 \\
\hline HDF3CGF:CXCL9/MIG & -0.014809917 & -0.00568836 & -0.013077515 & -0.03424297 \\
\hline HDF3CGF:EGFR & 0.06364468 & 0.03357548 & 0.041452862 & 0.08710626 \\
\hline HDF3CGF:M-CSF & -0.001592574 & -0.010155368 & 0.01178382 & 0.005057344 \\
\hline HDF3CGF:MMP-1 & 0.04436401 & 0.027910933 & 0.02086079 & 0.003195706 \\
\hline HDF3CGF:PAI-I & -0.0880825 & -0.035160776 & 0.02382087 & 0.045141462 \\
\hline HDF3CGF:Proliferation_72hr & -0.12750264 & -0.03704038 & 0.012045057 & -0.1430148 \\
\hline HDF3CGF:SRB & -0.017372949 & -0.003555416 & -0.001745853 & -0.018309938 \\
\hline HDF3CGF:TIMP-1 & 0.039774045 & 0.03352405 & 0.028443664 & 0.025769245 \\
\hline HDF3CGF:TIMP-2 & -0.030578965 & -0.027251022 & -0.049004275 & -0.050400723 \\
\hline KF3CT:CCL2/MCP-1 & -0.048402444 & -0.032944813 & 0.013337301 & 0.005257566 \\
\hline KF3CT:CD54/ICAM-1 & -0.029552544 & -0.005985037 & -0.000959767 & 0.003247434 \\
\hline KF3CT:CXCL10/IP-10 & -0.011499337 & -0.008892694 & -0.009339187 & -0.002120542 \\
\hline KF3CT:CXCL8/LL-8 & -0.040259246 & -0.04370168 & -0.013660076 & -0.009919132 \\
\hline KF3CT:CXCL9/MIG & -0.009291041 & -0.00411381 & 0.005500144 & 0.001149831 \\
\hline KF3CT:IL-1alpha & -0.008286367 & -0.001178096 & 0.015165027 & 0.00433823 \\
\hline KF3CT:MMP-9 & 0.022513619 & 0.027633062 & 0.009886623 & 0.011650259 \\
\hline
\end{tabular}




\begin{tabular}{|c|c|c|c|c|}
\hline KF3CT:PAI-I & -0.082011156 & -0.04940652 & -0.04434619 & -0.009646845 \\
\hline KF3CT:SRB & 0.010696541 & 0.014324753 & -0.006395097 & -0.00299773 \\
\hline KF3CT:TIMP-2 & -0.014866818 & -0.0351477 & -0.021619644 & -0.06568444 \\
\hline KF3CT:UPA & -0.008607538 & -0.005485167 & -0.019420946 & -0.03212772 \\
\hline MyoF:alpha-SM Actin & -0.14153543 & -0.00733878 & -0.010656554 & -0.017320806 \\
\hline MyoF:bFGF & 0.000977766 & -0.0123598 & 0.004552919 & -0.006476836 \\
\hline MyoF:CD106/VCAM-1 & -0.05871583 & -0.048847463 & -0.003235315 & -0.027644984 \\
\hline MyoF:Collagen I & -0.06251417 & 0.004576547 & -0.011493983 & -0.021129811 \\
\hline MyoF:Collagen III & -0.04656379 & -0.021940028 & -0.007659735 & -0.019271228 \\
\hline MyoF:Collagen IV & -0.09848201 & -0.03262687 & -0.038812462 & -0.036180686 \\
\hline MyoF:CXCL8/IL-8 & 0.07592801 & 0.017904645 & -0.005634633 & -0.023416836 \\
\hline MyoF:Decorin & -0.021894615 & -0.030071774 & -0.032945108 & -0.020738916 \\
\hline MyoF:MMP-1 & 0.059466634 & 0.004617964 & -0.007234862 & -0.012415375 \\
\hline MyoF:PAI-I & -0.09233016 & -0.018710261 & -0.02486909 & -0.025921669 \\
\hline MyoF:SRB & -0.034306314 & 0.007883242 & 0.013027566 & 0.007086372 \\
\hline MyoF:TIMP-1 & -0.020526847 & -0.027231764 & -0.003898873 & -0.05419463 \\
\hline IMphg:CCL2/MCP-1 & 0.031333 & 0.024626449 & 0.06473886 & 0.021947468 \\
\hline IMphg:CCL3/MIP-1alpha & -0.104678325 & -0.054610956 & -0.037864264 & -0.02298837 \\
\hline IMphg:CD106/VCAM-1 & -0.08649805 & -0.08141199 & -0.03899005 & -0.077264495 \\
\hline IMphg:CD40 & -0.060102593 & -0.051174343 & -0.035836197 & -0.09072497 \\
\hline IMphg:CD62E/E-Selectin & -0.011314464 & -0.033335872 & -0.06734043 & -0.081917465 \\
\hline IMphg:CD69 & 0.015187494 & 0.017655084 & 0.020414464 & -0.01325386 \\
\hline IMphg:CXCL8/IL-8 & 0.046123914 & 0.002683227 & 0.013957504 & -0.019123556 \\
\hline IMphg:IL-1alpha & 0.06433137 & 0.028716598 & 0.004798883 & -0.008153519 \\
\hline IMphg:M-CSF & -0.04356594 & -0.001013589 & -0.03519419 & -0.014563869 \\
\hline IMphg:sIL-10 & -0.30317473 & -0.11420215 & 0.012344691 & 0.05483444 \\
\hline IMphg:SRB & -0.039434336 & -0.009151445 & -0.0178411 & -0.022784343 \\
\hline IMphg:SRB-Mphg & -0.036610577 & -0.04754209 & -0.040782508 & -0.021915002 \\
\hline
\end{tabular}


Figure S-3. Effects of LOU064 in the BioMAP Diversity plus panel of primary human cell systems. The $\mathrm{X}$-axis lists the quantitative protein-based biomarker readouts measured in each system. The Y-axis represents a log-transformed ratio of the biomarker readouts for the drugtreated sample $(n=1)$ over vehicle controls $(n \geq 6)$. The grey region around the $Y$-axis represents the 95\% significance envelope generated from historical vehicle controls. Biomarker activities are annotated when 2 or more consecutive concentrations change in the same direction relative to vehicle controls, are outside of the significance envelope, and have at least one concentration with an effect size $>20 \%$. Antiproliferative effects are indicated by a grey arrow. 

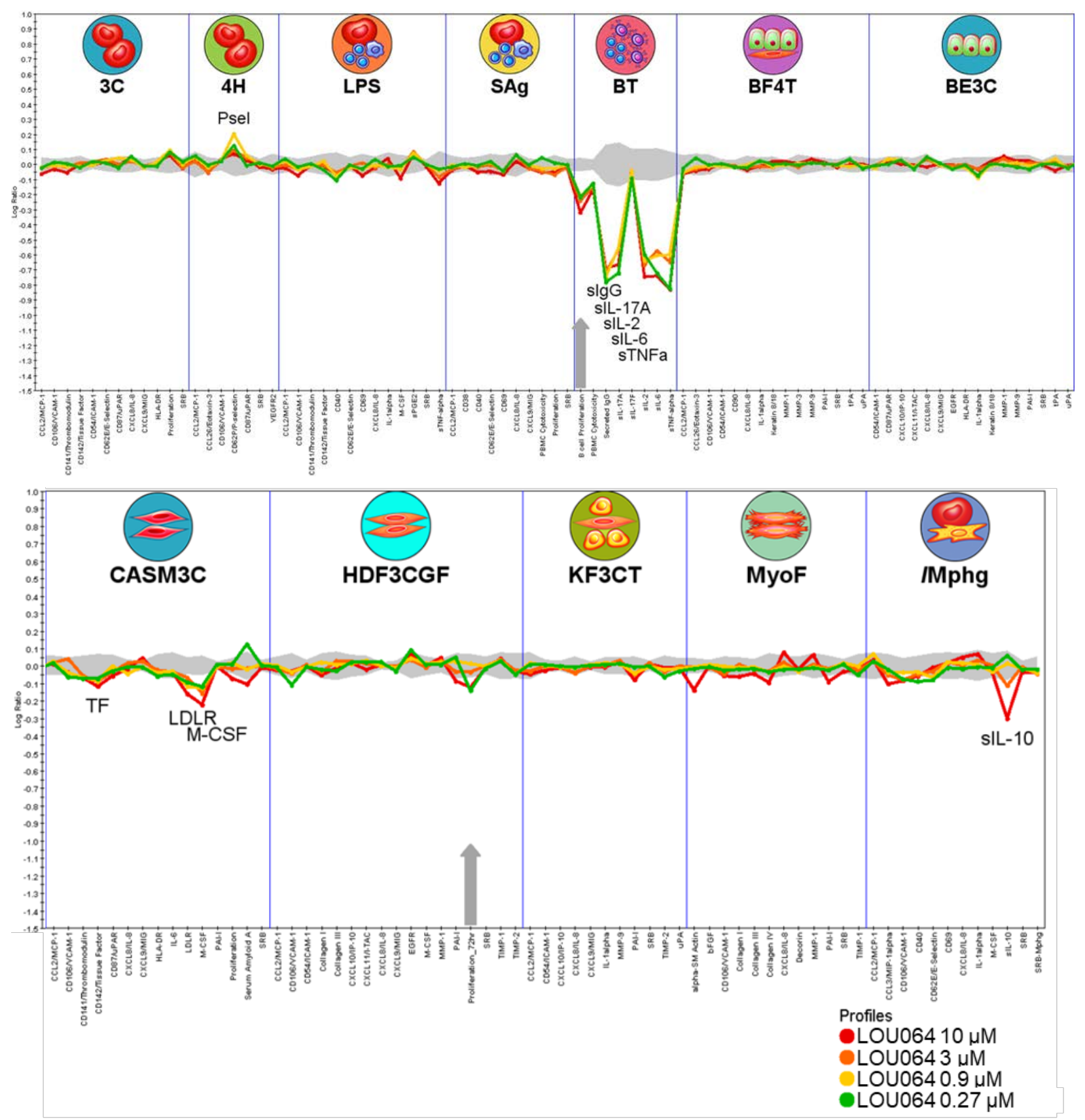
Figure S-4. Effects of LOU064 and ibrutinib in the BioMAP Diversity plus panel of primary human cell systems. LOU064 was tested at $10 \mu \mathrm{M}$ (red line), ibrutinib at $370 \mathrm{nM}$ (black line).

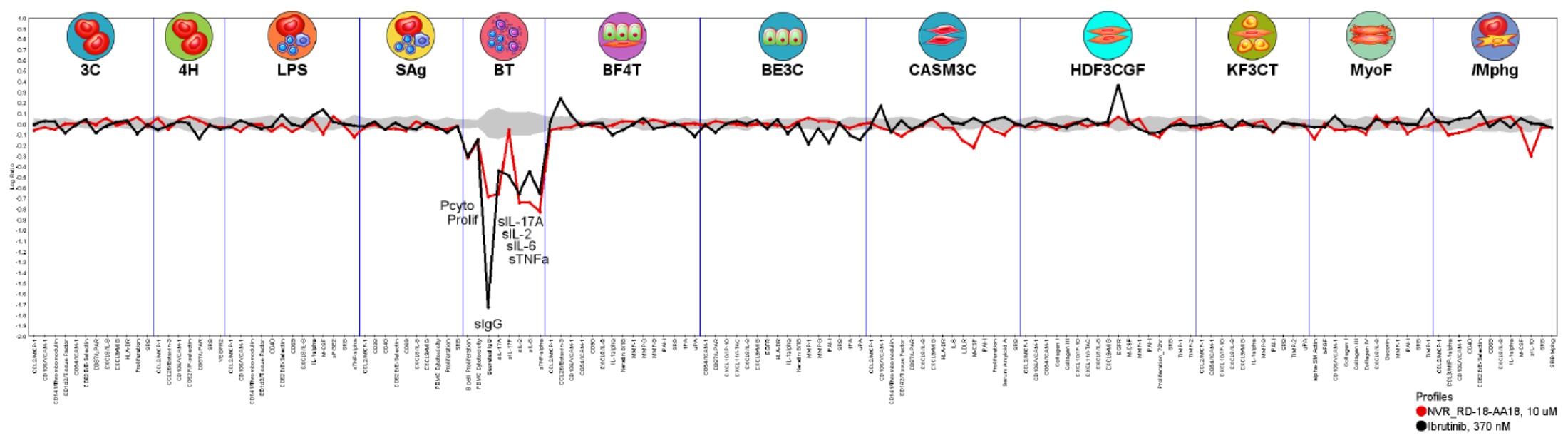


$\underline{\text { Table of Systems in BioMAP Diversity PLUS screen }}$

\begin{tabular}{|c|c|c|c|c|}
\hline $\begin{array}{l}\text { System } \\
\text { Name }\end{array}$ & Icon & Cell & Disease & Readouts \\
\hline $3 \mathrm{C}$ & & Venular endothelial cells & $\begin{array}{l}\text { Cardiovascular Disease, } \\
\text { Chronic Inflammation }\end{array}$ & $\begin{array}{l}\text { CCL2/MCP-1, CD106/VCAM-1, CD141/Thrombomodulin, CD142/Tissue Factor, } \\
\text { CD54/ICAM-1, CD62E/E-Selectin, CD87/uPAR, CXCL8/IL-8, CXCL9/MIG, HLA-DR, } \\
\text { Proliferation, SRB }\end{array}$ \\
\hline $4 \mathrm{H}$ & & Venular endothelial cells & $\begin{array}{l}\text { Allergy, Asthma, } \\
\text { Autoimmunity }\end{array}$ & $\begin{array}{l}\text { CCL2/MCP-1, CCL26/Eotaxin-3, CD106/VCAM-1, CD62P/P-Selectin, CD87/uPAR, SRB, } \\
\text { VEGFR2 }\end{array}$ \\
\hline LPS & & $\begin{array}{l}\text { Peripheral blood } \\
\text { mononuclear cells, } \\
\text { Venular endothelial cells }\end{array}$ & $\begin{array}{l}\text { Cardiovascular Disease, } \\
\text { Chronic Inflammation }\end{array}$ & $\begin{array}{l}\text { CCL2/MCP-1, CD106/VCAM-1, CD141/Thrombomodulin, CD142/Tissue Factor, CD40, } \\
\text { CD62E/E-Selectin, CD69, CXCL8/L-8, IL-1 alpha, M-CSF, sPGE2, SRB, sTNF-alpha }\end{array}$ \\
\hline SAg & & $\begin{array}{l}\text { Peripheral blood } \\
\text { mononuclear cells, } \\
\text { Venular endothelial cells }\end{array}$ & $\begin{array}{l}\text { Autoimmune Disease, } \\
\text { Chronic Inflammation }\end{array}$ & $\begin{array}{l}\text { CCL2/MCP-1, CD38, CD 40, CD62E/E-Selectin, CD69, CXCL8/L-8, CXCL9/MIG, PBMC } \\
\text { Cytotoxicity, Proliferation, SRB }\end{array}$ \\
\hline BT & & $\begin{array}{l}\text { B cells, Peripheral blood } \\
\text { mononuclear cells }\end{array}$ & $\begin{array}{l}\text { Allergy, Asthma, } \\
\text { Autoimmunity, Oncology }\end{array}$ & $\begin{array}{l}\text { B cell Proliferation, PBMC Cytotoxicity, Secreted IgG, sIL-17A, sIL-17F, sIL-2, sIL-6, } \\
\text { sTNF-alpha }\end{array}$ \\
\hline BF4T & & $\begin{array}{l}\text { Bronchial epithelial cells, } \\
\text { Dermal fibroblasts }\end{array}$ & $\begin{array}{l}\text { Allergy, Asthma, Fibrosis, } \\
\text { Lung Inflammation }\end{array}$ & $\begin{array}{l}\text { CCL2/MCP-1, CCL26/Eotaxin-3, CD106/VCAM-1, CD54/ICAM-1, CD90, CXCL8/L-8, IL- } \\
1 \text { alpha, Keratin 8/18, MMP-1, MMP-3, MMP-9, PAI-I, SRB, tPA, UPA }\end{array}$ \\
\hline BE3C & & Bronchial epithelial cells & COPD, Lung Inflammation & $\begin{array}{l}\text { CD54/ICAM-1, CD87/uPAR, CXCL10/IP-10, CXCL11/1-TAC, CXCL8/L-8, CXCL9/MIG, } \\
\text { EGFR, HLA-DR, IL-1 alpha, Keratin 8/18, MMP-1, MMP-9, PAI-I, SRB, IPA, UPA }\end{array}$ \\
\hline САSM 3 C & & $\begin{array}{l}\text { Coronary artery smooth } \\
\text { muscle cells }\end{array}$ & $\begin{array}{l}\text { Cardiovascular } \\
\text { Inflammation, Restenosis }\end{array}$ & $\begin{array}{l}\text { CCL2/MCP-1, CD106/VCAM-1, CD141/Thrombomodulin, CD142/Tissue Factor, } \\
\text { CD87/uPAR, CXCL8/L-8, CXCL9/MIG, HLA-DR, IL-6, LDLR, M-CSF, PAI-I, } \\
\text { Proliferation, Serum Amyloid A, SRB }\end{array}$ \\
\hline HDF3CGF & & Dermal fibroblasts & $\begin{array}{l}\text { Chronic Inflammation, } \\
\text { Fibrosis }\end{array}$ & $\begin{array}{l}\text { CCL2/MCP-1, CD106/VCAM-1, CD54/ICAM-1, Collagen I, Collagen III, CXCL10/IP-10, } \\
\text { CXCL11/I-TAC, CXCL8/IL-8, CXCL9/MIG, EGFR, M-CSF, MMP-1, PAI-I, } \\
\text { Proliferation_72hr, SRB, TIMP-1, TIMP-2 }\end{array}$ \\
\hline $\mathrm{KF} 3 \mathrm{CT}$ & & $\begin{array}{l}\text { Dermal fibroblasts, } \\
\text { Keratinocytes }\end{array}$ & Dermatitis, Psoriasis & $\begin{array}{l}\text { CCL2/MCP-1, CD54/ICAM-1, CXCL10/IP-10, CXCL8/LL-8, CXCL9/MIG, IL-1 alpha, } \\
\text { MMP-9, PAI-I, SRB, TIMP-2, UPA }\end{array}$ \\
\hline MyoF & & Lung fibroblasts & $\begin{array}{l}\text { Chronic Inflammation, } \\
\text { Fibrosis, Matrix } \\
\text { Remodeling, Wound }\end{array}$ & $\begin{array}{l}\text { alpha-SM Actin, bFGF, CD106/VCAM-1, Collagen I, Collagen III, Collagen IV, } \\
\text { CXCL8/IL-8, Decorin, MMP-1, PAI-1, SRB, TIMP-1 }\end{array}$ \\
\hline MyoF & & Lung fibroblasts & $\begin{array}{l}\text { Chronic Inflammation, } \\
\text { Fibrosis, Matrix } \\
\text { Remodeling, Wound } \\
\text { Healing }\end{array}$ & $\begin{array}{l}\text { alpha-SM Actin, bFGF, CD106/VCAM-1, Collagen I, Collagen III, Collagen IV, } \\
\text { CXCL8/IL-8, Decorin, MMP-1, PAI-1, SRB, TIMP-1 }\end{array}$ \\
\hline Mphg & & $\begin{array}{l}\text { Macrophages, Venular } \\
\text { endothelial cells }\end{array}$ & $\begin{array}{l}\text { Cardiovascular Disease, } \\
\text { Chronic Inflammation, } \\
\text { Restenosis }\end{array}$ & $\begin{array}{l}\text { CCL2/MCP-1, CCL3/MIP-1 alpha, CD106/VCAM-1, CD40, CD62E/E-Selectin, CD69, } \\
\text { CXCL8/IL-8, IL-1 alpha, M-CSF, sIL-10, SRB, SRB-Mphg }\end{array}$ \\
\hline
\end{tabular}




\section{Receptor panel screen}

\begin{tabular}{|c|c|c|c|c|}
\hline $\begin{array}{l}\text { Assay Name } \\
\text { ATPase, } \mathrm{Na}^{+} / \mathrm{K}^{+} \text {, Heart, Pig }\end{array}$ & $\begin{array}{l}\text { Specie } \\
\text { pig }\end{array}$ & $\begin{array}{l}\text { Rep. } \\
2\end{array}$ & $\begin{array}{l}\text { Conc. } \\
10 \mu \mathrm{M}\end{array}$ & $\begin{array}{l}\% \operatorname{lnh} . \\
-21\end{array}$ \\
\hline Deacetylase, Sirtuin SIRT6 & hum & 2 & $10 \mu \mathrm{M}$ & -4 \\
\hline Lipoxygenase 12-LO & hum & 2 & $10 \mu \mathrm{M}$ & 4 \\
\hline Lipoxygenase 5-LO & hum & 2 & $10 \mu \mathrm{M}$ & 7 \\
\hline $\begin{array}{l}\text { Protein Tyrosine Phosphatase, PTEN } \\
\text { (MMAC1) }\end{array}$ & hum & 2 & $10 \mu \mathrm{M}$ & 1 \\
\hline $\begin{array}{l}\text { Protein Tyrosine Phosphatase, PTPN11 } \\
\text { (SHP-2) }\end{array}$ & hum & 2 & $10 \mu \mathrm{M}$ & 4 \\
\hline $\begin{array}{l}\text { Protein Tyrosine Phosphatase, PTPN6 } \\
\text { (PTP1C, SHP-1) }\end{array}$ & hum & 2 & $10 \mu \mathrm{M}$ & -4 \\
\hline Thromboxane Synthase & hum & 2 & $10 \mu \mathrm{M}$ & 11 \\
\hline Angiotensin $\mathrm{AT}_{2}$ & hum & 2 & $10 \mu \mathrm{M}$ & 7 \\
\hline APJ & hum & 2 & $10 \mu \mathrm{M}$ & 7 \\
\hline Bombesin BB1 & hum & 2 & $10 \mu \mathrm{M}$ & -1 \\
\hline Bombesin BB2 & hum & 2 & $10 \mu \mathrm{M}$ & 13 \\
\hline Bombesin BB3 & hum & 2 & $10 \mu \mathrm{M}$ & 1 \\
\hline Bradykinin $\mathrm{B}_{1}$ & hum & 2 & $10 \mu \mathrm{M}$ & 7 \\
\hline Bradykinin $\mathrm{B}_{2}$ & hum & 2 & $10 \mu \mathrm{M}$ & 2 \\
\hline Calcium Channel N-Type & rat & 2 & $10 \mu \mathrm{M}$ & 0 \\
\hline Cannabinoid $\mathrm{CB}_{2}$ & hum & 2 & $10 \mu \mathrm{M}$ & 89 \\
\hline Chemokine CCR1 & hum & 2 & $10 \mu \mathrm{M}$ & 1 \\
\hline Chemokine CCR2B & hum & 2 & $10 \mu \mathrm{M}$ & s2 \\
\hline Chemokine CCR4 & hum & 2 & $10 \mu \mathrm{M}$ & 21 \\
\hline Chemokine CCR5 & hum & 2 & $10 \mu \mathrm{M}$ & 10 \\
\hline Chemokine CXCR2 (IL-8R & hum & 2 & $10 \mu \mathrm{M}$ & -11 \\
\hline Cholecystokinin $\mathrm{CCK}_{2}\left(\mathrm{CCK}_{\mathrm{B}}\right)$ & hum & 2 & $10 \mu \mathrm{M}$ & 15 \\
\hline Dopamine $\mathrm{D}_{4.4}$ & hum & 2 & $10 \mu \mathrm{M}$ & 9 \\
\hline Endothelin $\mathrm{ET}_{\mathrm{B}}$ & hum & 2 & $10 \mu \mathrm{M}$ & -9 \\
\hline Estrogen ER $\beta$ & hum & 2 & $10 \mu \mathrm{M}$ & 15 \\
\hline $\mathrm{GABA}_{\mathrm{A}}$, Chloride Channel, TBOB & rat & 2 & $10 \mu \mathrm{M}$ & 4 \\
\hline Galanin GAL1 & hum & 2 & $10 \mu \mathrm{M}$ & -9 \\
\hline Glucagon & hum & 2 & $10 \mu \mathrm{M}$ & 3 \\
\hline Glutamate, AMPA & rat & 2 & $10 \mu \mathrm{M}$ & -1 \\
\hline Glutamate, Kainate & rat & 2 & $10 \mu \mathrm{M}$ & 22 \\
\hline Glutamate, NMDA, Agonism & rat & 2 & $10 \mu \mathrm{M}$ & 2 \\
\hline Glutamate, NMDA, Glycine & rat & 2 & $10 \mu \mathrm{M}$ & 6 \\
\hline
\end{tabular}

Note: $g p=$ Guinea pig; hum=Human 


\begin{tabular}{|c|c|c|c|c|}
\hline Assay Name & Specie & Rep. & Conc. & $\%$ Inh. \\
\hline Glutamate, NMDA, Phencyclidine & rat & 2 & $10 \mu \mathrm{M}$ & 0 \\
\hline Glutamate, NMDA, Polyamine & rat & 2 & $10 \mu \mathrm{M}$ & -8 \\
\hline Glycine, Strychnine-Sensitive & rat & 2 & $10 \mu \mathrm{M}$ & 1 \\
\hline Gonadotropin-Releasing Hormone & hum & 2 & $10 \mu \mathrm{M}$ & 9 \\
\hline Histamine $\mathrm{H} 4$ & hum & 2 & $10 \mu \mathrm{M}$ & 11 \\
\hline Imidazoline I2, Central & rat & 2 & $10 \mu \mathrm{M}$ & 16 \\
\hline Inositol Trisphosphate IP3 & rat & 2 & $10 \mu \mathrm{M}$ & -8 \\
\hline Leukotriene, BLT (LTB4) & hum & 2 & $10 \mu \mathrm{M}$ & -1 \\
\hline Leukotriene, Cysteinyl CysLT1 & hum & 2 & $10 \mu \mathrm{M}$ & 18 \\
\hline Leukotriene, Cysteinyl CysLT2 & hum & 2 & $10 \mu \mathrm{M}$ & -2 \\
\hline Melanocortin MC1 & hum & 2 & $10 \mu \mathrm{M}$ & -1 \\
\hline Melanocortin MC5 & hum & 2 & $10 \mu \mathrm{M}$ & -1 \\
\hline Melatonin MT1 & hum & 2 & $10 \mu \mathrm{M}$ & 2 \\
\hline Melatonin MT2 & hum & 2 & $10 \mu \mathrm{M}$ & -1 \\
\hline Muscarinic M4 & hum & 2 & $10 \mu \mathrm{M}$ & 4 \\
\hline Muscarinic M5 & hum & 2 & $10 \mu \mathrm{M}$ & 6 \\
\hline Neuromedin U NMU1 & hum & 2 & $10 \mu \mathrm{M}$ & 14 \\
\hline Neuromedin U NMU2 & hum & 2 & $10 \mu \mathrm{M}$ & -2 \\
\hline Neuropeptide Y Y1 & hum & 2 & $10 \mu \mathrm{M}$ & 2 \\
\hline Neurotensin NT1 & hum & 2 & $10 \mu \mathrm{M}$ & 3 \\
\hline Nicotinic Acetylcholine $\alpha 1$, Bungarotoxin & hum & 2 & $10 \mu \mathrm{M}$ & 12 \\
\hline Orexin OX1 & hum & 2 & $10 \mu \mathrm{M}$ & -3 \\
\hline Oxytocin & hum & 2 & $10 \mu \mathrm{M}$ & 17 \\
\hline Platelet Activating Factor (PAF) & hum & 2 & $10 \mu \mathrm{M}$ & -8 \\
\hline Potassium Channel [KA] & rat & 2 & $10 \mu \mathrm{M}$ & -1 \\
\hline Prostanoid CRTH2 & hum & 2 & $10 \mu \mathrm{M}$ & 10 \\
\hline Prostanoid DP & hum & 2 & $10 \mu \mathrm{M}$ & 11 \\
\hline Prostanoid EP1 & hum & 2 & $10 \mu \mathrm{M}$ & 28 \\
\hline Prostanoid EP2 & hum & 2 & $10 \mu \mathrm{M}$ & -15 \\
\hline Prostanoid EP3 & hum & 2 & $10 \mu \mathrm{M}$ & 11 \\
\hline Prostanoid EP4 & hum & 2 & $10 \mu \mathrm{M}$ & 8 \\
\hline Prostanoid FP & hum & 2 & $10 \mu \mathrm{M}$ & 12 \\
\hline Prostanoid IP & hum & 2 & $10 \mu \mathrm{M}$ & 14 \\
\hline Ryanodine RyR3 & rat & 2 & $10 \mu \mathrm{M}$ & -7 \\
\hline Serotonin (5-Hydroxytryptamine) 5-HT4 & gp & 2 & $10 \mu \mathrm{M}$ & 34 \\
\hline
\end{tabular}

Note: $g p=$ Guinea pig; hum=Human 


\begin{tabular}{|c|c|c|c|c|}
\hline Assay Name & Specie & Rep. & Conc. & $\% \operatorname{lnh}$. \\
\hline Serotonin (5-Hydroxytryptamine) $5-\mathrm{HT}_{6}$ & hum & 2 & $10 \mu \mathrm{M}$ & 0 \\
\hline Serotonin (5-Hydroxytryptamine) $5-\mathrm{HT}_{7}$ & hum & 2 & $10 \mu \mathrm{M}$ & -7 \\
\hline Sigma $\sigma_{1}$ & hum & 2 & $10 \mu \mathrm{M}$ & 0 \\
\hline Somatostatin sst1 & hum & 2 & $10 \mu \mathrm{M}$ & 1 \\
\hline Somatostatin sst3 & hum & 2 & $10 \mu \mathrm{M}$ & -17 \\
\hline Somatostatin sst5 & hum & 2 & $10 \mu \mathrm{M}$ & 3 \\
\hline Tachykinin $\mathrm{NK}_{3}$ & hum & 2 & $10 \mu \mathrm{M}$ & 10 \\
\hline Thyrotropin Releasing Hormone (TRH) & hum & 2 & $10 \mu \mathrm{M}$ & 1 \\
\hline Transporter, Choline & rat & 2 & $10 \mu \mathrm{M}$ & 10 \\
\hline Transporter, GABA & rat & 2 & $10 \mu \mathrm{M}$ & 5 \\
\hline Tumor Necrosis Factor (TNF), Non-Selective & hum & 2 & $10 \mu \mathrm{M}$ & 10 \\
\hline Urotensin II & hum & 2 & $10 \mu \mathrm{M}$ & -16 \\
\hline Vasoactive Intestinal Peptide VIP 1 & hum & 2 & $10 \mu \mathrm{M}$ & -15 \\
\hline Vasopressin $V_{2}$ & hum & 2 & $10 \mu \mathrm{M}$ & 0 \\
\hline Vitamin $\mathrm{D}_{3}$ & hum & 2 & $10 \mu \mathrm{M}$ & 7 \\
\hline
\end{tabular}

Note: $g p=$ Guinea pig; hum=Human

\section{Functional assays:}

\section{Assay Name}

Histamine $\mathrm{H}_{2}$, CAMP

Cannabinoid $\mathrm{CB}_{2}$, GTPYS Binding

\begin{tabular}{lllrlr}
\multicolumn{1}{c}{ Species } & Tissue & Rep. & Conc. Criteria & & Ag. \\
hum & $\begin{array}{l}\text { AequoZen } \\
\text { frozen cells }\end{array}$ & 2 & $10 \mu \mathrm{M} \geq \pm 50 \%$ & $0 \%$ \\
hum & & 2 & $1 \mu \mathrm{M} \geq \pm 50 \%$ & $2 \%$ \\
hum & & 2 & $0.1 \mu \mathrm{M} \geq \pm 50 \%$ & $11 \%$ \\
hum & HEK-293 & 2 & $10 \mu \mathrm{M} \geq \pm 50 \%$ & $2 \%$ \\
hum & & 2 & $1 \mu \mathrm{M} \geq \pm 50 \%$ & $0 \%$ \\
hum & & 2 & $0.1 \mu \mathrm{M} \geq \pm 50 \%$ & $2 \%$
\end{tabular}

Spec. Tissue

Rep. Conc. Criteria Ag. Ant.

$\begin{array}{lllllll}\text { hum } & \text { CHO-K1 cells } & 2 & 10 \mu \mathrm{M} & \geq \pm 50 \% & -5 \% & \mathrm{ND} \\ \text { hum } & 2 & 1 \mu \mathrm{M} & \geq \pm 50 \% & 13 \% & \mathrm{ND} \\ \text { hum } & 2 & 0.1 \mu \mathrm{M} & \geq \pm 50 \% & -2 \% & \mathrm{ND} \\ \text { hum } & 2 & 10 \mathrm{nM} & \geq \pm 50 \% & 2 \% & \mathrm{ND} \\ \text { hum } & 2 & 1 \mathrm{nM} & \geq \pm 50 \% & -2 \% & \mathrm{ND} \\ \text { hum } & \text { CHO-K1 cells } & 2 & 10 \mu \mathrm{M} & \geq \pm 50 \% & \mathrm{ND} & 4 \% \\ \text { hum } & 2 & 1 \mu \mathrm{M} & \geq \pm 50 \% & \mathrm{ND} & 6 \% \\ \text { hum } & 2 & 0.1 \mu \mathrm{M} & \geq \pm 50 \% & \mathrm{ND} & 9 \% \\ \text { hum } & 2 & 10 \mathrm{nM} & \geq \pm 50 \% & \mathrm{ND} & 3 \% \\ \text { hum } & 2 & 1 \mathrm{nM} & \geq \pm 50 \% & \mathrm{ND} & 7 \%\end{array}$

Note: Ag.=Agonist; Ant.=Antagonist; ND=Assay Test Not Done hum=Human 


\section{In vitro BTK Inhibition Kinetics}

In biochemical assays of BTK enzymatic activity with recombinant full-length human BTK LOU064 showed very rapid inhibition of BTK. We assessed the level of inhibition of biochemical BTK activity in this assay starting from the earliest timepoint with detectable substrate phosphorylation at 3 minutes after addition of compound and substrate. Figure S-5 (left panel) shows the concentration-dependent inhibition of substrate phosphorylation over time. To compensate for the increase of phospho-substrate signal over time, figure S-5 (right panel) shows the same data normalized to the maximal BTK activity for each timepoint. The levels of BTK inhibition by LOU064 in this assay did not show relevant shift over time with IC $_{50}$ in the range of $4.5 \mathrm{nM}$ at 3 minutes, $4.6 \mathrm{nM}$ at 6 minutes, $9.0 \mathrm{nM}$ at 10 minutes and $7.2 \mathrm{nM}$ at 15 minutes, suggesting that the covalent inhibition is completed within 3 minutes of compound addition. These $\mathrm{IC}_{50}$ are in a similar range as those from other assay formats (at an ATP concentration of $65 \mu \mathrm{M}$ and an enzyme concentration of $30 \mathrm{nM})$. We therefore conclude that LOU064 shows potent and fast BTK inhibition within the time-frame we technically were able to assess in biochemcial assays of BTK inhibition. The very fast kinetics of covalent binding of LOU064 to purified BTK prevented the determination of accurate and meaningful classical biochemical reaction parameters such as $k_{\text {inact }} / K_{\mathrm{i}}$. 
Figure S-5. Concentration and time dependence of BTK inhibition by LOU064. The left panel shows the concentration-dependent inhibition of substrate phosphorylation by BTK over time after compound and enzyme are mixed. To compensate for the increase of phospho-substrate signal over time, the right panel shows the same data normalized to the maximal BTK activity for each time point.
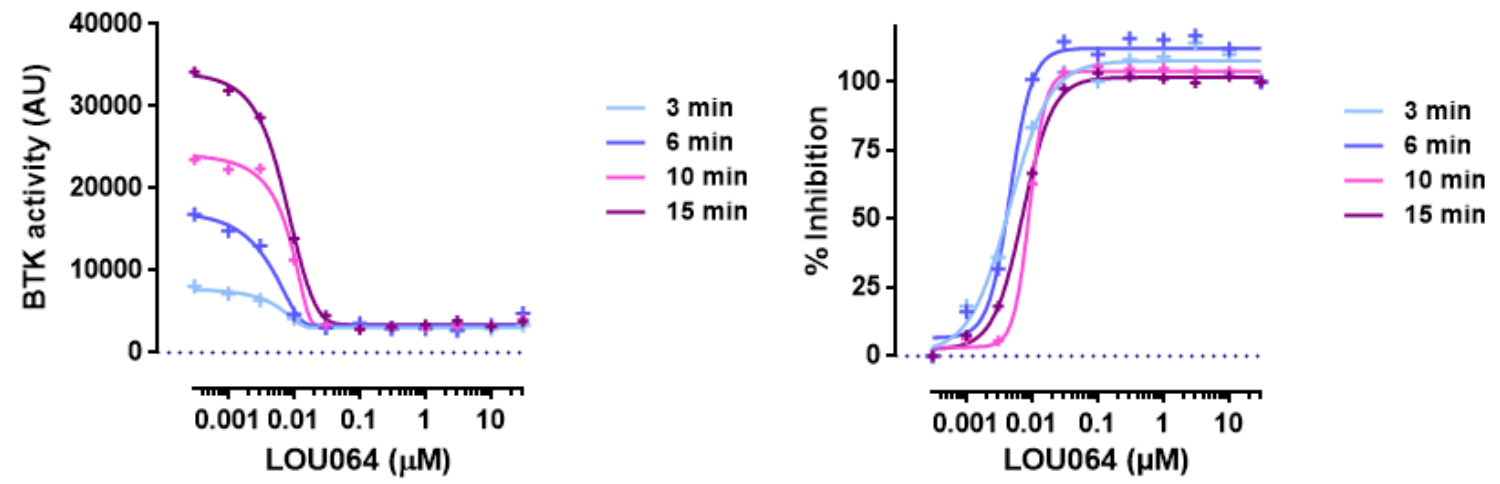


\section{ANIMAL STUDIES}

All animal studies described here were performed according to Swiss animal welfare laws and specifically according to animal licences BS-1151, BS-1182 and BS-1244 issued by the BaselStadt Cantonal Veterinary Office.

\section{Inhibition of Antibody Response to Sheep Red Blood Cells}

Female OFA rats were immunized with 2 x 10\% $/ \mathrm{ml}$ SRBCs in a volume of $0.5 \mathrm{ml} 0.9 \% \mathrm{NaCl}$ by i.v. injection. LOU064 was suspended in 0.5\% MC/0.5 \% Tween80/99 \% water and was applied p.o. at stated doses q.d. Five days later the number of anti-SRBC antibody secreting splenocytes was assessed in a plaque forming cell assay. ${ }^{12,13}$ In brief, agarose dishes were prepared using $0.7 \%$ agarose (SERVA) in Hanks' Balanced Salt solution pH 7.3 (Gibco, with added 1 mg phenolred $/ 100 \mathrm{ml})$. A single cell spleen suspension $\left(30 \times 10^{6} / \mathrm{ml}\right)$ from each immunized animal was prepared and plated with fresh antigen (SRBC, $40 \times 10^{8} / \mathrm{ml}$ ) onto the soft agar (50 $\mu \mathrm{l}$

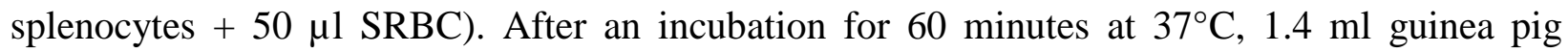
complement $10 \%$ (Harlan) was added and incubation continued for another 60 minutes at $37^{\circ} \mathrm{C}$. The addition of complement allows detection of hemolysis mediated by SRBC-specific IgM. Hemolytic plaques were counted and the percent inhibition was calculated compared to vehicle controls.

\section{Collagen-Induced Arthritis}

Female Lewis rats (Janvier) were immunized with porcine collagen type II (Chondrex, Redmond, USA) in incomplete Freund's adjuvant (IFA, Difco, Detroit, USA) by intradermal injection into the base of the tail under isoflurane anesthesia. After 7 days, the animals were boosted 
intradermally with a fresh collagen solution in IFA at a site adjacent to the base of the tail. Once a sufficient number of animals had developed arthritis on day 12 after immunization, they were randomized into treatment groups to achieve the same average swelling score in each group. LOU064 was suspended in $0.5 \%$ MC/0.5 \% Tween80/9 9\% water and was applied p.o. at doses of $0.3,3,10$ and $30 \mathrm{mg} / \mathrm{kg}$ q.d. Compound treatment started on day 12 and continued until day 25. Swelling of hind paws was scored 3 times a week. Scoring was done on a composite scale of 0-12 per rat, evaluating each paw by visual inspection in the metatarsal region with score $0-3$ and in the ankle with score 0-3, thus obtaining maximally score 6 per paw. The scoring system used was: 0 = no detectable sign of inflammation; 1 = light swollen metatarsal region; 2 = more obviously swollen metatarsal region; 3 = ankylosis or severely swollen metatarsal region. The paw scores were summed to obtain a score for each individual animal. 


\section{References}

(1) Takai, K.; Shinomiya, N.; Kaihara, H.; Yoshida, N.; Moriwake, T.; Utimoto, K. Transformation of Aldehydes into (E)-1-Alkenylboronic Esters with a Geminal Dichromium Reagent Derived from a Dichloromethylboronic Ester and $\mathrm{CrCl}_{2}$. Synlett 1995, 1995, 963-964.

(2) Raheem, I. T.; Goodman, S. N.; Jacobsen, E. N. Catalytic Asymmetric Total Syntheses of Quinine and Quinidine. J. Am. Chem. Soc. 2004, 126, 706-707.

(3) Paulini, R.; Müller, K.; Diederich, F. Orthogonal Multipolar Interactions in Structural Chemistry and Biology. Angew. Chemie Int. Ed. 2005, 44, 1788-1805.

(4) Kabsch, W. XDS. Acta Crystallogr. Sect. D Biol. Crystallogr. 2010, 66, 125-132.

(5) McCoy, A. J.; Grosse-Kunstleve, R. W.; Adams, P. D.; Winn, M. D.; Storoni, L. C.; Read, R. J. Phaser Crystallographic Software. J. Appl. Crystallogr. 2007, 40, 658-674.

(6) Emsley, P.; Cowtan, K. Coot: Model-Building Tools for Molecular Graphics. Acta Crystallogr. Sect. D Biol. Crystallogr. 2004, 60, 2126-2132.

(7) Bricogne, G., Blanc, E., Brandl, M., Flensburg, C., Keller, P., Paciorek, W., Roversi, P., Sharff, A., Smart, O.S., Vonrhein, C., Womack, T. O. BUSTER. Global Phasing Ltd: Cambridge, United Kingdom 2004.

(8) Kiener, P. A.; Rankin, B. M.; Burkhardt, A. L.; Schieven, G. L.; Gilliland, L. K.; Rowley, R. B.; Bolen, J. B.; Ledbetter, J. A. Cross-Linking of Fc Gamma Receptor I (Fc Gamma RI) and Receptor II (Fc Gamma RII) on Monocytic Cells Activates a Signal Transduction Pathway Common to Both Fc Receptors That Involves the Stimulation of P72 Syk Protein Tyrosine Kinase. J. Biol. Chem. 1993, 268, 24442-24448.

(9) Fleit, H. B.; Kobasiuk, C. D. The Human Monocyte-Like Cell Line THP-1 Expresses Fc $\gamma$ RI 
and FC $\gamma$ RII. J. Leukoc. Biol. 1991, 49, 556-565.

(10) Marsh, C. B.; Anderson, C. L.; Lowe, M. P.; Wewers, M. D. Monocyte IL-8 Release Is Induced by Two Independent Fc Gamma R- Mediated Pathways. J. Immunol. 1996, 157, 2632-2637.

(11) Pulz, R.; Angst, D.; Dawson, J.; Gessier, F.; Gutmann, S.; Hersperger, R.; Hinniger, A.; Janser, P.; Koch, G.; Revesz, L.; Vulpetti, A.; Waelchli, R.; Zimmerlin, A.; Cenni, B. Design of Potent and Selective Covalent Inhibitors of Bruton’s Tyrosine Kinase Targeting an Inactive Conformation. ACS Med. Chem. Lett. 2019, 10, 1467-1472.

(12) Jerne, N. K.; Nordin, A. A. Plaque Formation in Agar by Single Antibody-Producing Cells. Science 1963, 140, 405.

(13) Barington, T.; Heilmann, C. An Improved Haemolytic Plaque Assay for the Detection of Cells Secreting Antibody to Bacterial Antigens. J. Immunol. Methods 1992, 146, 129-137. 